US Army Corps

of Engineers

Waterways Experiment

Station

Monitoring Completed Navigation Projects Progran

\title{
Mouth of the Colorado River, Texas, Monitoring Program
}

by David B. King, Terri L. Prickett

Approved For Public Release; Distribution Is Unlimited

Prepared for Headquarters, U.S. Army Corps of Engineers 
The contents of this report are not to be used for advertising, publication, or promotional purposes. Citation of trade names does not constitute an official endorsement or approval of the use of such commercial products.

The findings of this report are not to be construed as an official Department of the Army position, unless so designated by other authorized documents. 


\section{Mouth of the Colorado River, Texas, Monitoring Program}

by David B. King, Terri L. Prickett

U.S. Army Corps of Engineers Waterways Experiment Station 3909 Halls Ferry Road

Vicksburg, MS 39180-6199

Final report

Approved for public release; distribution is unlimited

Prepared for U.S. Army Corps of Engineers

Washington, DC 20314-1000 


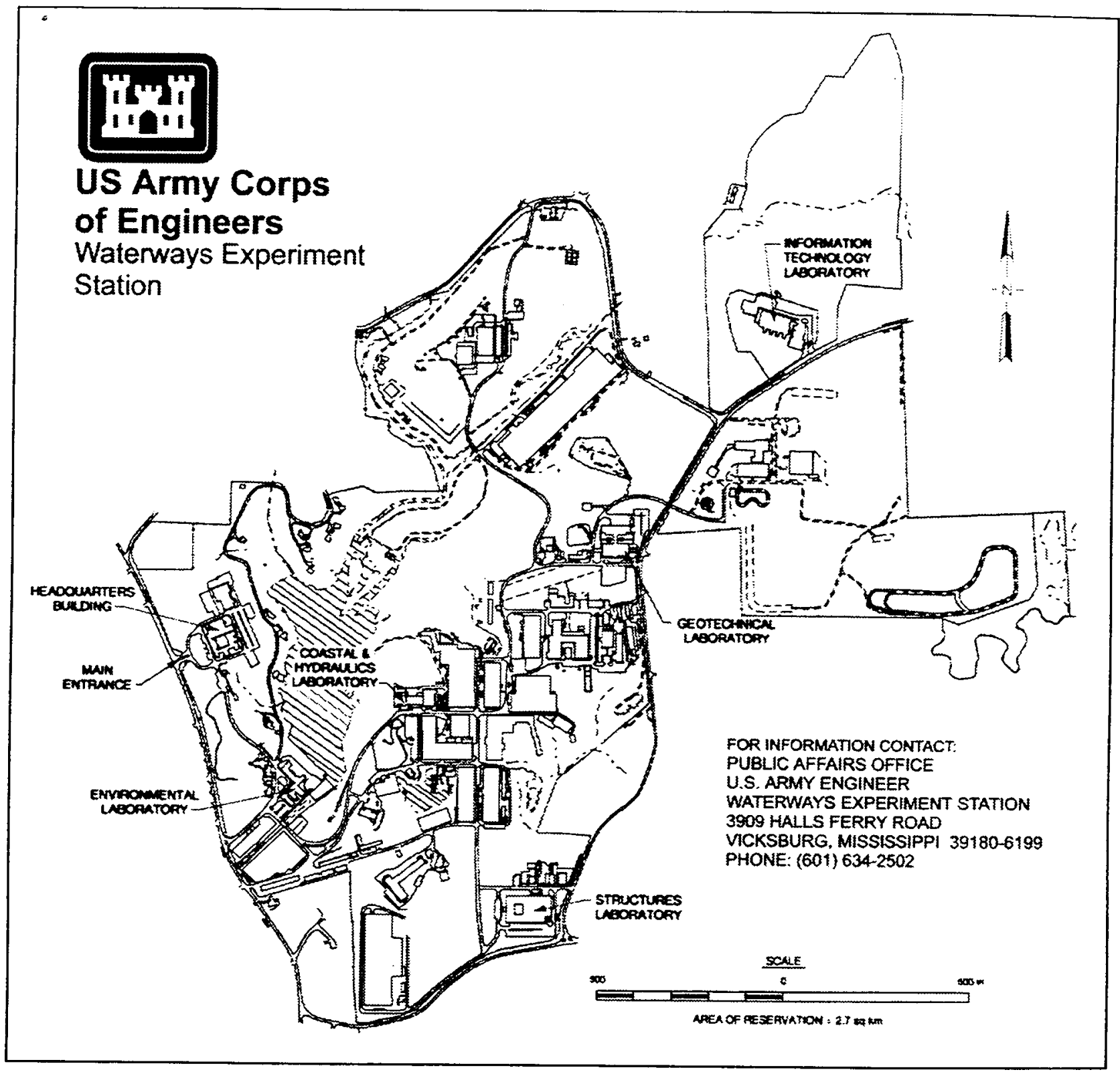

Waterways Experiment Station Cataloging-in-Publication Data

King, David Byron, 1949

Mouth of the Colorado River, Texas, Monitoring Program / by David B. King, Terri L. Prickett ; prepared for U.S. Army Corps of Engineers.

98 p. : ill. ; $28 \mathrm{~cm}$. - (Technical report ; CHL-98-2)

Includes bibliographic references.

1. Colorado River (Tex.) 2. Inland navigation - Colorado River (Tex.) 3. Jetties. 4. Sediment transport - Colorado River (Tex.) I. Prickett, Terri L. II. United States. Army. Corps of Engineers. III. U.S. Army Engineer Waterways Experiment Station. IV. Coastal and Hydraulics Laboratory (U.S. Army Engineer Waterways Experiment Station) V. Title. VI. Series: Technical report (U.S. Army Engineer Waterways Experiment Station) ; CHL-98-2.

TA7 W34 no.CHL-98-2 


\section{Contents}

Preface ............................. vii

Conversion Factors, Non-SI to SI Units of Measurement . . . . . . . . . ix

1--Introduction $\ldots \ldots \ldots \ldots \ldots \ldots \ldots \ldots \ldots \ldots$

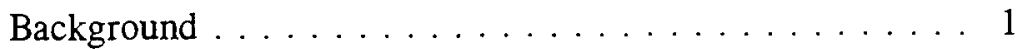

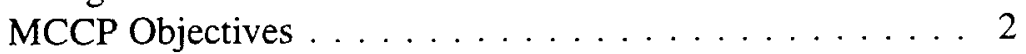

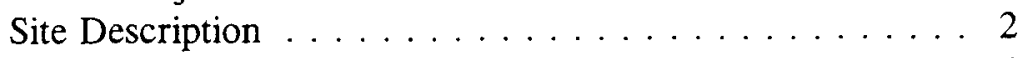

Scope of Report . . . . . . . . . . . . . . 4

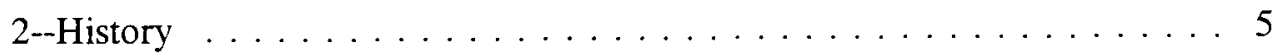

Local Geology . . . . . . . . . . . . . . . 5

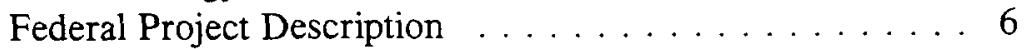

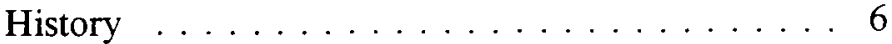

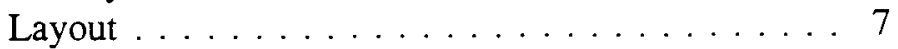

Jetty and entrance channel design $\ldots \ldots \ldots 7$

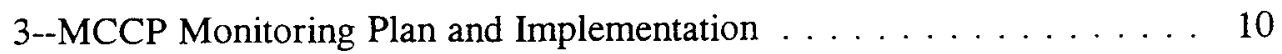

Monitoring Plan Overview . . . . . . . . . . . . 10

Data Collection . . . . . . . . . . . . . . 11

Long-term deployments . . . . . . . . . . 11

Short-term deployments . . . . . . . . . . . 12

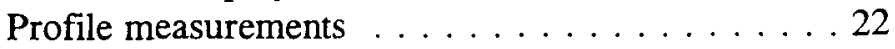

SWG data . . . . . . . . . . . . 27

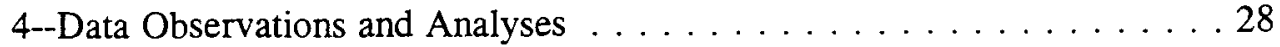

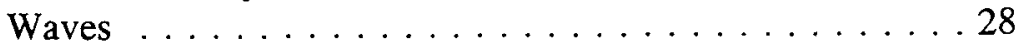

Surf Zone Sediment Transport Measurements . . . . . . . 31

Shoreline and Nearshore Bathymetry Changes ... . . . . . 35

Impoundment Basin Surveys . . . . . . . . . . . . . . . . . . . . . . 36

Sediment Grain Size . . . . . . . . . . . . . . . 37

Tides and Currents . . . . . . . . . . . . 40

5--Prediction of Sediment Transport Rates . . . . . . . . . . 43

Calculations of Longshore Transport Rate . . . . . . . . 43

Methods . . . . . . . . . . . . . . . . 43

SPM Method Calculations . . . . . . . . . . . 44

Surf Zone Measurements . . . . . . . . . . . . . . 46

Impoundment Basin and Dredging Measurements . . . . . 50

Summary . . . . . . . . . . . . . . 51 
6--Evaluation of Project Design $\ldots \ldots \ldots \ldots 3$

General Discussion . . . . . . . . . . . . . 53

Test of Hypotheses . . . . . . . . . . . . . . . . 54

7--Discussion and Recommendations . . . . . . . . . . . . . 56

Management of the Mouth of the Colorado River . . . . . 56

Lessons Learned for Future Weir Jetty Designs . . . . . . . 57

References ........................ 58

Appendix A: Monthly Percent Occurrence of Wave Height and Period . . A1

Appendix B: Summary of All Wave Heights, Periods, and Directions . . . B1

Appendix C: Surf Zone Sediment Transport Rates . . . . . . . . . . . C C1

SF298

\section{List of Figures}

Figure 1. Colorado River location map . . . . . . . . . . . . . . 3

Figure 2. Plan view of the Colorado River project site $\ldots \ldots \ldots \ldots$

Figure 3. Location of instruments deployed at the mouth of the Colorado

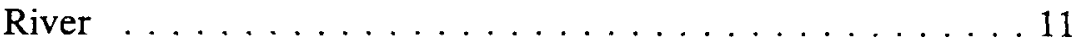

Figure 4. Instrumented platform $\ldots \ldots \ldots \ldots \ldots \ldots \ldots$

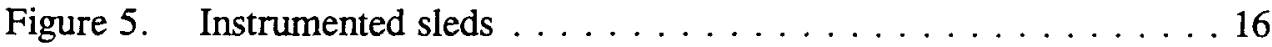

Figure 6. ADCP deployed in equipment mount . . . . . . . . . . . . 19

Figure 7. FOBS-instrumented tripod . . . . . . . . . . . . . . . 19

Figure 8. FOBS-instrumented tripods deployed with WES platform . . . 23

Figure 9. Survey line locations (from Liang (1995)) . . . . . . . . . . 24

Figure 10. Rod setup for offshore geodimeter surveying $\ldots \ldots \ldots$

Figure 11. Mean and median monthly wave heights $\left(H_{m 0}\right)$ at Colorado River, TX . . . . . . . . . . . . . . . . . . 29

Figure 12. Mean and median monthly peak wave periods at Colorado River, TX . . . . . . . . . . . . . . . . . . 29 
Figure 13. Wave rose for the mouth of the Colorado River, TX

Figure 14. Directional distribution of wave energy flux

in kilowatts per meter of crest length

Figure 15. Example of platform OBS output on 16 January $1992 \ldots . . .32$

Figure 16. Example of platform ECM output on 16 January 1992 . . . . 33

Figure 17. Regions of vertical integration of local sediment

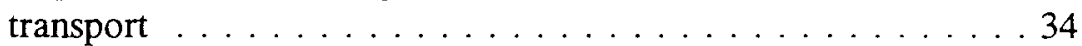

Figure 18. Example of FOBS tripod data on 4 May $1990 . \quad \ldots$. . . . . 34

Figure 19. Shoreline positions northeast of the mouth of the Colorado River

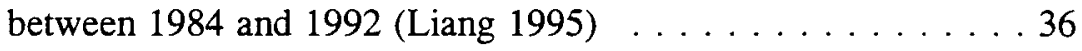

Figure 20. Example of impoundment basin surveys $\ldots \ldots \ldots 38$

Figure 21. Representative grain size distribution curve for the beach . . . 39

Figure 22. Tide curve taken on June 1990 from wave gage successive mean water levels . . . . . . . . . . . . . . . . 41

Figure 23. Example of ADCP-measured current flow at the mouth of the Colorado River, TX . . . . . . . . . . . . . . . . . 41

Figure 24. Example of relative suspended sediment load at the mouth of the Colorado River, TX . . . . . . . . . . . . . . . . 42

Figure 25. Offshore current rose for Colorado River, TX . . . . . . . . 42

Figure 26. Monthly sediment transport rate, in cubic meters per month . . 46

Figure 27. Plot of impoundment basin infilling rates $\ldots \ldots \ldots 50$

\section{List of Tables}

Table 1. Wave Gage Deployment Information . . . . . . . . . 13

Table 2. Wave Data Availability . . . . . . . . . . . . . . 14

Table 3. Platform Deployment Information . . . . . . . . . . 17

Table 4. Sled Locations $\ldots \ldots \ldots \ldots \ldots$ 
Table 5. FOBS Tripod Deployment Information $\ldots \ldots \ldots 21$

Table 6. Nearshore Beach Profiles . . . . . . . . . . . . . . 25

Table 7. Available Impoundment Basin Bathymetric Surveys

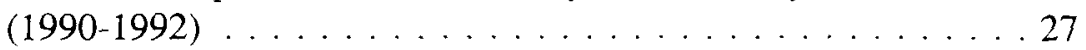

Table 8. Dredging Volumes at the Mouth of the Colorado River . . . . 27

Table 9. Calculated Impoundment Basin Material Volume . . . . . . . 38

Table 10. Surf Zone Sediment Grain-Size Distributions . . . . . . . . 39

Table 11. Selected Texas Longshore Sediment Transport Estimates . . . . 44

Table 12. Average Sediment Transport Rates Calculated by

SPM Method . . . . . . . . . . . . . . . . . 46

Table 13. Regression and Correlation of OBS and SPM Transport Data for July 1991 , from White $(1994) \ldots \ldots$. . . . . . . . 48

Table 14. Regression and correlation of OBS and SPM Transport Data for January 1992, from White (1994) . . . . . . . . . . . 48

Table 15. Regression and Correlation of Breaker Gage Data with OBS and 10-m Gage Data for January 1992 . . . . . . . . . . . . . . . 49 


\section{Preface}

The study described herein was conducted by the U. S. Army Engineer Waterways Experiment Station (WES) Coastal and Hydraulics Laboratory $(\mathrm{CHL})$. The CHL was formed in October 1996 with the merger of the WES Coastal Engineering Research Center and Hydraulics Laboratory. Dr. James R. Houston is the Director of the CHL and Messrs. Richard A. Sager and Charles C. Calhoun, Jr., are Assistant Directors.

The study was performed under Work Unit 22113 "Mouth of the Colorado River, Texas" in the Monitoring Completed Coastal Projects Program which was renamed in October 1996 as the Monitoring Completed Navigation Projects (MCNP) Program. The MCNP Program Manager during the study was Ms. Carolyn Holmes. Technical Monitors of the MCNP Program at Headquarters, U.S. Army Corps of Engineers were Messrs. John H. Lockhart, Barry W. Holliday, and Charles B. Chesnutt.

Dr. Thomas E. White was Principal Investigator (PI) during the data collection and much of the data analysis portion of this program. Dr. David B. King, Jr., was PI for a portion of the data analysis and the report preparation phase of the program. Ms. Terri L. Prickett co-authored and coordinated final report preparation. During the course of this study, Drs. White and King, and Ms. Prickett were supervised by Mr. William L. Preslan, Chief, Prototype Measurement and Analysis Branch (PMAB), and Mr. Thomas W. Richardson, Chief, Coastal Sediments and Engineering Division, CHL.

Other CHL personnel made substantial contributions to the program. The data collection systems were designed by Messrs. Ralph E. Ankeny, William E. Grogg, Gary L. Howell, and James Rosati III of PMAB. Field team members included Messrs. Larry G. Caviness, William M. Kucharski, Douglas C. Lee, Charles J. Mayers, Jeff Sewell, and Mses. Debra Shafer and Rhonda M. Lofton of PMAB, and Messrs. Michael W. Leffler and C. Ray Townsend of the Field Research Facility at Duck, NC. Data analysis was performed by Ms. Rhonda M. Lofton, Mr. James P. McKinney, and Dr. Joon P. Rhee of PMAB. Additional research was performed by Dr. Reginald A. Beach, College of Atmospheric Sciences, Oregon State University under Contract DACW39-90-K-0009, and by Mr. Guoxiong Liang, Scripps Institution of Oceanography (SIO), University of California, San Diego under the supervision of Dr. Richard J. Seymour, SIO, under Contract DACW39-90K-0007. Other data measurements, principally impoundment basin surveys, were supplied by the U.S. Army Engineer District, Galveston. 
Dr. Robert W. Whalin was Director of WES at the time of publication of this report. COL Robin R. Cababa, EN, was WES Commander.

The contents of this report are not to be used for advertising, publication or promotional purposes. Citation of trade names does not constitute an official endorsement or approval of the use of such commercial products. 


\section{Conversion Factors, Non-SI to SI Units of Measurement}

Non-SI units of measurement used in this report can be converted to SI units as follows:

\begin{tabular}{||l|l|l||}
\hline Multiply & By & To Obtain \\
\hline acres & 4.046 .873 & square meters \\
\hline cubic feet & 0.2831685 & cubic meters \\
\hline cubic yards & 0.764559 & cubic meters \\
\hline degrees (angle) & 0.01745329 & radians \\
\hline feet & 0.3048 & meters \\
\hline inches & 2.54 & centimeters \\
\hline knots (international) & 0.51444444 & meters per second \\
\hline miles (U.S. nautical) & 1.852 & kilometers \\
\hline miles (U.S. statute) & 1.609347 & kilometers \\
\hline pounds (mass) & 0.4535924 & kilograms \\
\hline tons (short) & 0.9078 & tons (metric) \\
\hline
\end{tabular}




\section{Introduction}

\section{Background}

The Monitoring Completed Coastal Projects (MCCP) ${ }^{1}$ Program was established in 1981 by Headquarters, U. S. Army Corps of Engineers (HQUSACE) to evaluate the performance of the Corps in planning, design, construction, and operation and maintenance of selected Civil Works coastal projects. The MCCP is funded by the Construction, Operations, and Readiness Division of HQUSACE and managed by the U. S. Army Engineer Waterways Experiment Station (WES) Coastal and Hydraulics Laboratory (CHL), formerly the Coastal Engineering Research Center (CERC) ${ }^{2}$. Oversight and assistance are provided by a Field Review Group (FRG) composed of representatives of Corps Divisions with coastal interests, Technical Monitors from HQUSACE, and the Coastal Engineering Research Board. CERC provides technical advice and direction for program preparation and execution (Headquarters, Department of the Army 1993). The program's objective is to acquire information through intensive monitoring of coastal projects in order to improve the following:

a. Project purpose and attainment.

$b$. Design procedures.

c. Construction methods.

$d$. Operation and maintenance techniques.

Potential projects are nominated by coastal districts and selected for monitoring during an annual Program Review attended by the FRG. Selection is based on the potential for improving general procedures for application at other sites or for solving site-specific problems.

1 The MCCP Program was renamed the Monitoring Completed Navigation Projects (MCNP) Program in October 1996. In this report, however, the program will be referred to as MCCP.

2 The CHL was formed in October 1996 with the merger of the WES Coastal Engineering Research Center (CERC) and Hydraulics Laboratory. For historical purposes, however, any reference to the WES laboratory will be cited as CERC. 
The Colorado River project was nominated for inclusion in the MCCP by the U.S. Army Engineer District, Galveston (SWG) in 1984. It was approved for monitoring in FY90 because it met both generic and site-specific selection criteria. The monitoring effort was conducted by CERC and private contractors in cooperation with SWG.

\section{MCCP Objectives}

The main objectives of the MCCP Monitoring Program at the Colorado River project were as follows:

a. Evaluate the design and efficiency of the weir jetty and adjacent impoundment basin so that project maintenance requirements and costs could be more accurately established.

b. Develop and improve equations for computing longshore sediment transport in the vicinity of Colorado River, Texas.

c. Determine what sediment transport equations work best in the surf zone.

d. Collect data to aid in efforts to improve future designs of similar Corps of Engineers projects.

Conclusions for Objectives $a$ and $d$ are discussed in Chapters 6 and 7 . Conclusions for Objective $b$ are discussed in Chapter 5. Objective $c$ is not addressed in significant detail in this report. The surf zone sediment transport data collected at this site are being used along with similar data collected elsewhere to develop better surf zone sediment transport relationships. That work is primarily funded through other work units.

\section{Site Description}

The mouth of the Colorado River is located on the Texas coastline near the town of Matagorda and runs through the Matagorda Peninsula into the Gulf of Mexico. It is located approximately midway between the ports of Galveston and Corpus Christi. The Colorado River is intersected by the Gulf Intracoastal Waterway (GIWW) approximately $10.5 \mathrm{~km}$ above the mouth. A channel at the GIWW and the Tiger Island Channel, located approximately $2.4 \mathrm{~km}$ above the river mouth, allows the flood flows of the Colorado River to discharge into west Matagorda Bay (U. S. Army Engineer District, Galveston 1977). Figure 1 is a map of the MCCP project area. The mouth of the Colorado River is influenced by tidal flows in the Gulf and is subjected to tropical storms and hurricanes originating in the Gulf of Mexico. The frequency of moderate-magnitude floods in the Colorado River is once every 1.3 years (U. S. Department of Commerce 1987). 


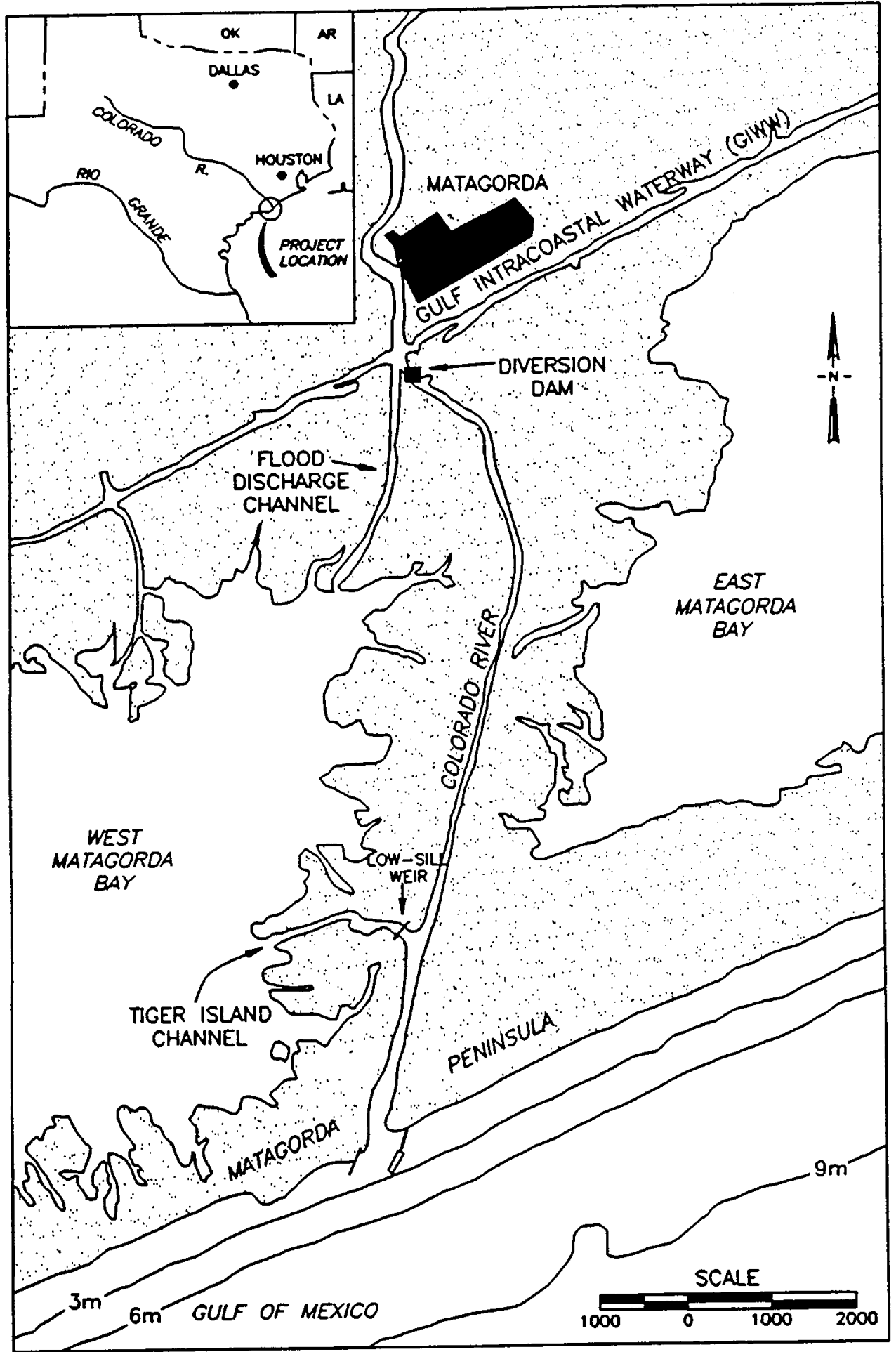

Figure 1. Colorado River location map (scale is in meters) 
Historical shoreline changes in the vicinity of the Colorado River mouth indicate a predominant net southwestward movement of littoral material. Infrequent movement of littoral materials has been observed in the northeasterly direction and is considered of little significance. The Matagorda Peninsula shoreline surrounding the mouth of the Colorado River is composed of terrigenous sand, shell, and rock fragments derived from Pleistocene and Holocene deposits that were eroded from the upland areas along the Colorado River and from the eastern shoreface (McGowen and Brewton 1975).

\section{Scope of Report}

This report provides an overview of the monitoring effort of the Corps project at the mouth of the Colorado River, TX. It includes background information, objectives of the study, the data collection plans and procedures, data analysis, an evaluation of the project, and conclusions and recommendations. The purpose of this report is to synopsize the study, present the collected data, and state important conclusions for the general-interest reader. Chapter 1 of this report is the introduction. Chapter 2 is the history of the area, and planning, design, construction, and operation of the project. Chapter 3 lists the objectives of the study and describes the monitoring plan that evolved in an attempt to address both site-specific and general issues. Chapter 4 presents the monitoring analyses and results. Chapter 5 discusses the calculation of a long-shore sediment transport rate by various methods.

Chapter 6 evaluates the project design using several hypotheses which were tested by this study. Chapter 7 recommends future maintenance efforts at the site. The appendices give the MCCP project objectives, several tables of wave and sediment transport data, and lessons learned during the data collection experiments. 


\section{History}

\section{Local Geology}

Geologic development in the area of the mouth of the Colorado River consisted of alternating deposition and erosion related to the advancement and retreat of continental glaciers, respectively, during the Pleistocene Epoch. Barrier islands and lagoons were produced during the Holocene Epoch (beginning approximately 18,000 years Before Present (BP)) due to several temporary stillstands during sea-level rise. Development of the modern-day shoreline began approximately 3,000 to $2,500 \mathrm{BP}$. Sediment deposition from major fluvial systems in the area including the Colorado River caused the progradation of bayhead deltas, thereby influencing shoreline development in the Matagorda Bay Area and development of the Matagorda Peninsula (McGowen and Brewton 1975).

Approximately 1,000 years ago, the Colorado River began discharging into Matagorda Bay in the vicinity of present-day Matagorda, TX. Historical records show that geologically, the Gulf and mainland shorelines have not changed significantly in the last 140 years.

Local changes occurring within this century have also affected the shorelines of Matagorda Bay Peninsula. Historical records of surveys made in 1908 show that the Colorado River channel was clogged with tangled masses of logs and brush embedded with silt which restricted floodwater outflow. In 1929 the log jam was removed by local conservation and reclamation districts. As a result of the clearance, a substantial volume of sediment was transported into Matagorda Bay, creating a delta that prograded completely across the bay. In 1936 local interests dredged a straight channel through the prograded delta and Matagorda Peninsula that allowed the Colorado River to discharge into the Gulf of Mexico (U. S. Army Engineer District, Galveston 1977).

Human activities caused other local changes along the coastline (McGowen and Brewton 1975). Construction of the Matagorda Ship Channel Jetties in 1965 (located approximately $40 \mathrm{~km}$ southwest of the Colorado River) has resulted in accretion and erosion northeast and southwest of the jetties, respectively. 
Historically, the shoreline along the Matagorda Peninsula of the Texas coast has been erosional in nature (Morton, Peiper, and McGowen 1976; Paine and Morton 1989; Heilman 1995). Comparing topographic charts (dated 1855-1857) and aerial photographs (taken in 1937, 1956, 1965, and 1974), Morton, Peiper and McGowen (1976) found that a 30-km length of shoreline around the mouth of the Colorado River (their stations $12-31$ ) has retreated an average of $91 \mathrm{~m}$ over the time period $1856-1982(0.72 \mathrm{~m} /$ year $)$. Heilman (1995) found that over half of this amount ( $49 \mathrm{~m}$ or $0.39 \mathrm{~m} / \mathrm{year}$ ) could be attributed to sea level rise. The largest erosion rates in this section are just southwest of the river mouth, and the smallest rates are just northeast of it. By comparing changes in the shoreline before the river mouth was opened in 1935 to shoreline changes afterward (1856-1937 changes versus 1937-1982 changes) Heilman (1995) concluded that the Colorado River historically affected the shoreline for a distance $5.4 \mathrm{~km}$ northeast and $18.4 \mathrm{~km}$ southwest of the mouth. Effects may have extended further to the southwest, but were masked by overlapping effects of the Matagorda Ship Channel.

\section{Federal Project Description}

\section{History}

In 1937, Federal authorization was granted to build the GIWW approximately $10.5 \mathrm{~km}$ above the mouth of the Colorado River. Authorization was also provided for maintenance of a flood discharge channel (the 10.5-km reach of the Colorado River located between the GIWW and the channel mouth). Maintenance dredging of the channel was conducted in 1941 and 1953. The Tiger Island Channel, which serves as an outflow from the Colorado River to west Matagorda Bay, was dredged in the early 1950's (see Figure 1).

The Mouth of the Colorado River (MOCR) project was authorized by Section 101 of the River and Harbor Act of 1968, and included improvement to navigation features, construction of related recreational areas, and diversion of Colorado River flows into Matagorda Bay. Initiation of the MOCR project was delayed for several years as a result of interagency conflicts involving HQUSACE, natural resource agencies, local interests, and members of Congress. Eventually, the project was allowed to proceed and funding was appropriated in 1979 .

Construction of the jetty structures at the MOCR was completed in 1985 . Dredging the impoundment basin located between the jetties, the final step in this portion of the MOCR project, was completed in 1990. Material removed from the impoundment basin was discharged by pipeline dredge in the surf zone approximately $600 \mathrm{~m}$ southwest of the southwest jetty. 


\section{Layout}

The Colorado River navigation channel between its mouth and the GIWW is $10.5 \mathrm{~km}$ in length, $4 \mathrm{~m}$ deep and $300 \mathrm{~m}$ wide. The channel entrance to the Gulf of Mexico, which is protected by a pair of rubble-mound jetties, is $5 \mathrm{~m}$ deep and $60 \mathrm{~m}$ wide. All elevations, unless otherwise noted, refer to U.S. Army Corps of Engineers mean low tide datum, which is $0.43 \mathrm{~m}$ below National Geodetic Vertical Datum (NGVD). The jetty system includes a 300 -m-long weir on the northeast side of the entrance channel and an impoundment basin adjacent to the weir to trap southwesterly moving littoral material. The impoundment basin was constructed to allow for subsequent sand bypassing to the downdrift beaches of Matagorda Peninsula. Figure 2 is a plan view of the jetty system and impoundment basin.

Other inland features included in the MOCR federal project were not monitored by the MCCP. Diversion features include a channel and dam located just south of the GIWW and Colorado River intersection which are used to divert the flow of the Colorado river into Matagorda Bay, and a low-sill weir across the Tiger Island Channel to prevent increased saltwater intrusion in Matagorda Bay (see Figure 1). In May 1991, a dam was constructed across Tiger Island cut that closed communication between the Colorado River and West Matagorda Bay. The diversion canal which shunted the entire flow of the Colorado River into West Matagorda Bay was completed in July 1992. The diversion features were primarily built to provide for a separate flood discharge channel to reduce flood damages along the lower Colorado River channel. Additionally, these features were constructed to introduce fresh water and nutrients into Matagorda Bay to increase the commercial seafood catch from the bay system. Other features of the MOCR federal project at the river's intersection with the GIWW include a harbor, a turning basin, and two recreation areas.

\section{Jetty and entrance channel design}

The entrance channel and rubble-mound jetties were designed as a straight extension of the existing river channel into the Gulf. The seaward ends of the jetties are spaced about $400 \mathrm{~m}$ apart for adequate protection of the entrance channel and accommodation of any future channel enlargement. The northeast jetty extends about $120 \mathrm{~m}$ from the dune line to the shoreline and has a crown elevation of $+2.4 \mathrm{~m}$. At the shoreline, the jetty crown elevation drops to $+0 \mathrm{~m}$, to form a weir section, which extends $300 \mathrm{~m}$ into the Gulf. At the seaward end of the weir, the jetty crown is again at $+2.4 \mathrm{~m}$ to provide an emergent end to the jetty. This outer section of the jetty extends to about the 3.7-m depth contour and is slightly angled to act as a breakwater for the impoundment basin and entrance channel. Cover stone on the northeast jetty ranges in size from 3.6 to $5.5 \mathrm{mt}$ at the landward end to 14.5 to $16.3 \mathrm{mt}$ on the outer section. The southwest jetty was built based on a conventional design to prevent northeasterly moving littoral material from entering the navigation channel and provide a protected entrance for small craft during infrequent periods when waves approach from the southwest. The southwest jetty has a 


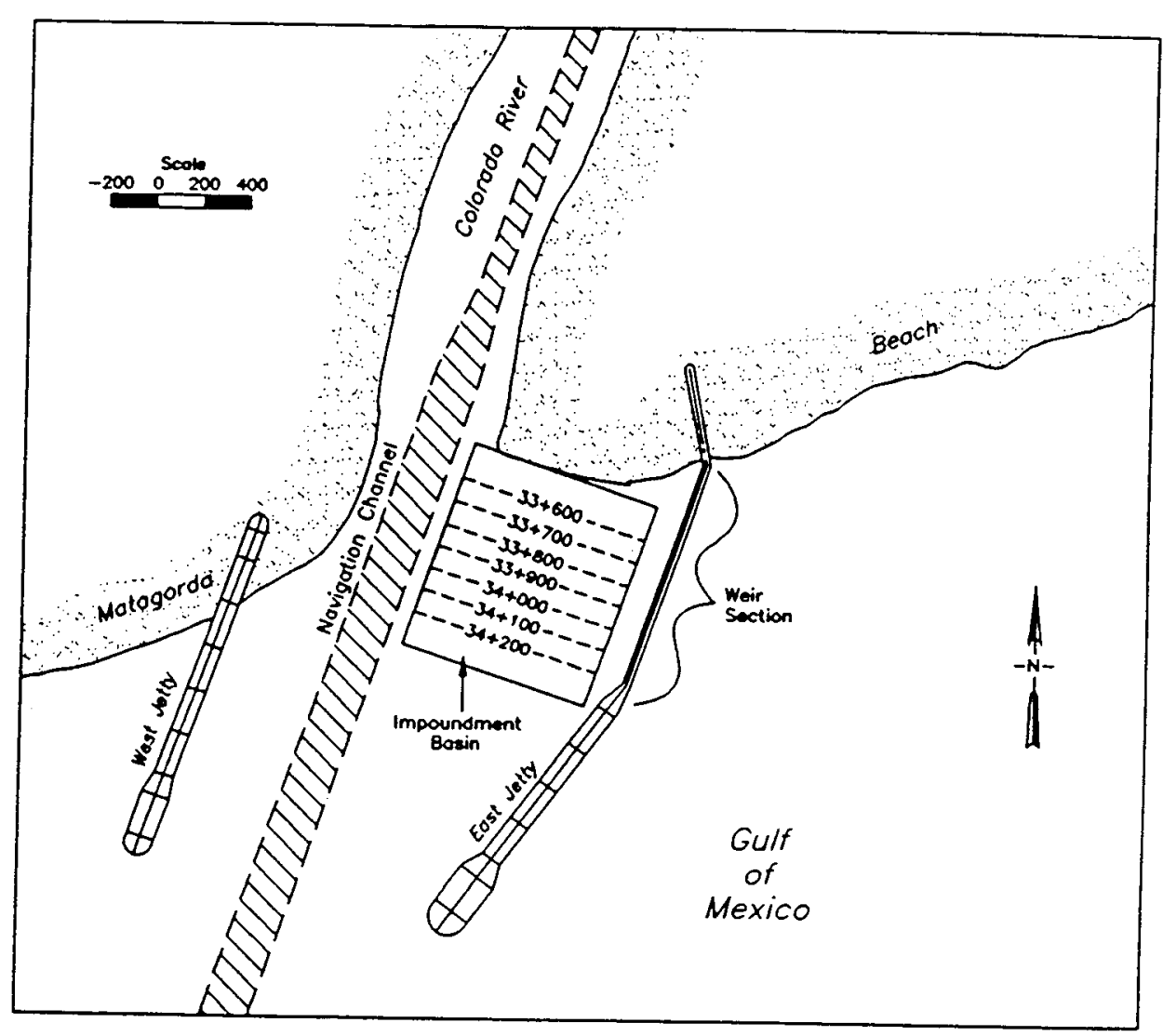

Figure 2. Plan view of the Colorado River project site

crown elevation of $+2.4 \mathrm{~m}$ and extends seaward to about the $1.5-\mathrm{m}$ depth contour. Cover stone on the southwest jetty ranges from 3.6 to $5.5 \mathrm{mt}$ at the landward end to 9 to $11 \mathrm{mt}$ on the outer section.

The impoundment basin is a rectangular area situated between the weir section of the northeast jetty and the entrance channel. It is positioned to trap the littoral material carried across the weir by the longshore currents. Prior to jetty construction, littoral drift estimates at the mouth of the Colorado River were obtained from two sources. A 7-year (1964-1971) sediment accumulation on the updrift jetties at the Matagorda Ship Channel ( $-40 \mathrm{~km}$ southwest of the Colorado River mouth) indicated that there was a southwesterly littoral drift in excess of 153,000 cubic meters/year. Also, a 14-month accumulation (1953-1954) in the mouth of the Colorado River between two dredging events was found to be 200,000 cubic meters. Based upon these data, the littoral drift was estimated to be 230,000 cubic meters/year, and the impoundment basin was designed to hold a 2-year supply of sediment, 460,000 cubic meters 
(U.S. Army Engineer District, Galveston 1977). The basin is roughly square (about $250 \mathrm{~m}$ on a side), and has a depth of $9 \mathrm{~m}$ with side slopes of 1:5.

Since initial construction, the impoundment basin has filled substantially more rapidly than expected, and, on occasion, the entrance channel has shoaled badly. This has led to SWG having to dredge more frequently and in greater volumes than expected. The post-completion dredging history is discussed in greater detail in Chapter 3. 


\section{MCCP Monitoring Plan and Implementation}

\section{Monitoring Plan Overview}

In the 1984 nomination of the MOCR for inclusion in the MCCP, a strong interest was expressed in evaluating the design and performance of the planned weir jetty system and establishing a database for future planning of similar jetty systems. Six hypotheses were developed to address the objectives. The hypotheses are as follows:

1. The weir-jetty system has minimal impact on adjacent beaches.

2. The weir should be on the northeast side of the inlet.

3. The weir is in proper cross-shore location, is at the correct elevation, and is the appropriate length.

4. The impoundment area is large enough and the anticipated dredging frequency is correct.

5. The impoundment basin trapping efficiency is high.

6. The northeast jetty length should extend $460 \mathrm{~m}$ past the end of the weir section (to the -3.7-m contour).

The Colorado River data collection effort, which was designed to address these hypotheses, was divided into three main components. First, offshore directional wave sensors were deployed at the site for the life of the data collection phase to obtain long-term, continuous wave, current, and water level information. The second component consisted of a series of intense, short-term field experiments that principally collected sediment transport data in the surf zone. Figure 3 shows the general location where instruments for both the long- and short-term measurements were deployed. Bathymetry surveys (beach 
profiles) of the adjacent shorelines were made by CERC during the short-term experiments and at other times, and were considered the third component of the data collection effort.

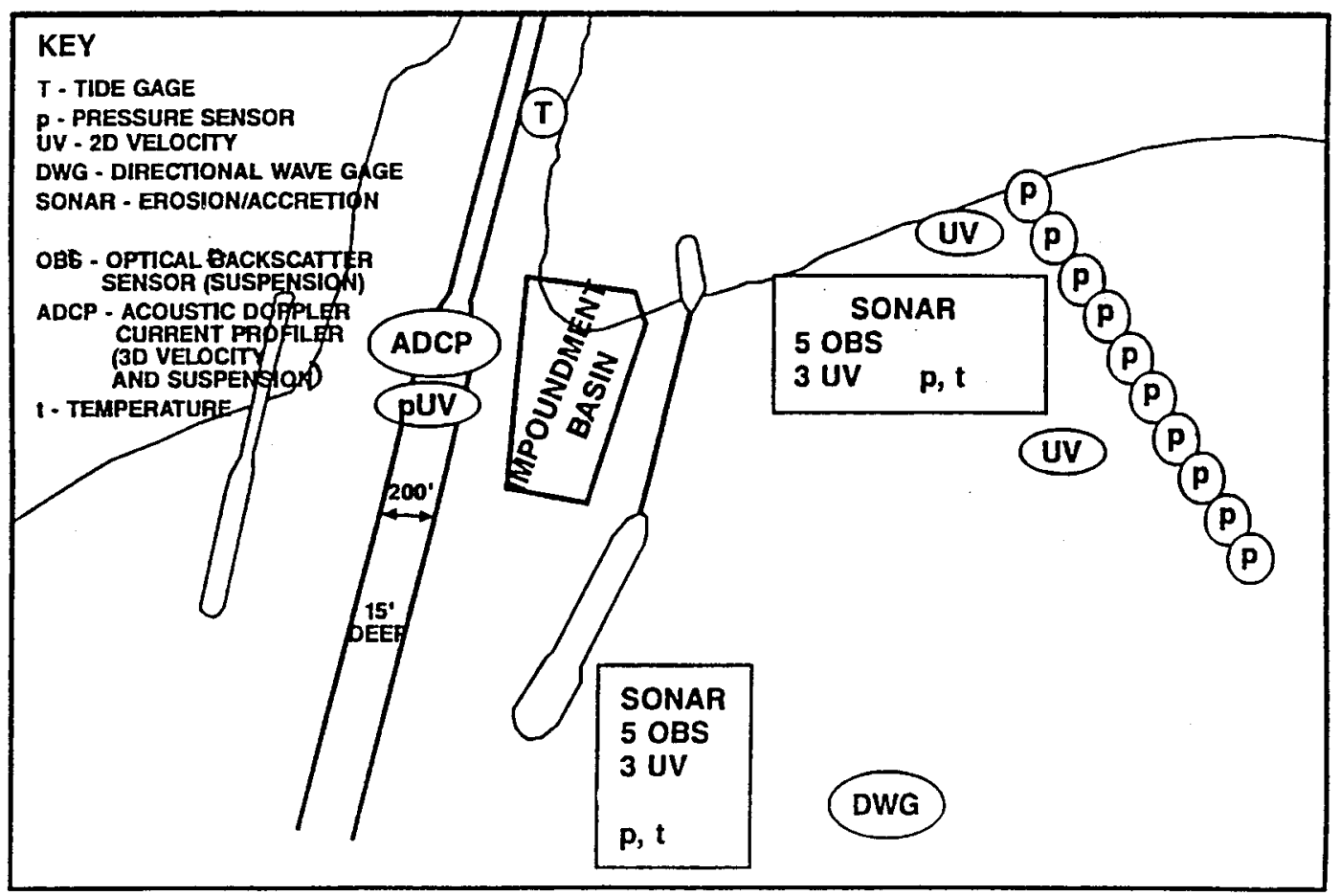

Figure 3. Location of instruments deployed at the mouth of the Colorado River (from White 1994)

Other important data were obtained from SWG. These data primarily included numerous bathymetric surveys of the impoundment basin and dredging records from the impoundment basin and mouth of the river.

\section{Data collection}

\section{Long-term deployments}

Continuous, long-term measurements of waves and water levels were conducted at the project site from 1990 to 1994 using two types of self-recording sensor packages, deployed in 10-m water depths approximately $3.2 \mathrm{~km}$ offshore of the northeast jetty. The first wave gage type was a combination of a strain gage pressure sensor $(\mathrm{P})$ and a co-located electromagnetic current meter (ECM) to measure the two components of horizontal water velocity $(u, v)$, known as a Puv gage. The Puvs were contained on a bottom-mounted, trawler-resistant steel pod. 
The second wave gage type was a newly developed directional wave gage, a DWG. This sensor package consisted of three Paros Scientific piezoelectric pressure sensors also mounted on a trawler-resistant seafloor pod in an equilateral triangle distribution. This instrument is further described in Howell (1992). Like the Puvs, the DWGs were self-recording.

In all cases, pod orientation (necessary to determine wave direction) was determined by divers following deployment and checked during retrieval. The pod also contained a power source, data storage components, and an acoustic transponder. Datasonic acoustic releasing transponders were used to assist in locating the equipment pods for data retrieval and gage changeouts.

The Puv's were programmed to collect hourly water level data (pressure and temperature) and current data (velocity and direction) in 300-sec (5-min) bursts at a $1-\mathrm{Hz}$ sampling rate. Wave data (height and period) were collected every $3 \mathrm{hr}$ in 2,048-sec bursts (approximately $34 \mathrm{~min}$ ) at a $1-\mathrm{Hz}$ sampling rate. Puv data were recorded onto a magnetic cassette with a storage capacity that permitted a deployment interval of about 6 months. When the instruments were retrieved, the data tapes were removed.

The DWG sampled output of the quartz pressure transducers at $1 \mathrm{~Hz}$ for 1,000-sec bursts (approximately $17 \mathrm{~min}$ ) hourly. Recorded data from both the Puv's and DWG were later downloaded to the CERC mainframe computer for subsequent analysis.

Initially, two Puv-instrumented pods were deployed in May 1990. Approximately every 6 months, the pods were retrieved and the sensors changed out. A total of six deployments were conducted, with the final retrieval occurring in April 1994. Table 1 provides gage and deployment information and Table 2 lists the wave data available by month.

Two SEADATA Thermal Data Recorders (TDR's) were deployed in the Colorado River near its mouth in May 1990 to collect tidal (water level) data. The TDR's were programmed to collect data by averaging $1-\mathrm{Hz}$ samples continuously over a 450-sec (7.5-min) interval. Attempts to locate the TDR's during the second deployment in December 1990 were unsuccessful. It is believed that the instruments were buried by sediments. No additional TDR's were deployed in the river for the rest of the monitoring period.

\section{Short-term deployments}

Three intensive, short-term field experiments were conducted in May 1990 , July 1991, and January 1992 to obtain a comprehensive data set of current, wave, and sediment transport measurements at the area of the jetty structures and impoundment basin. This section provides an overview of the equipment and procedures used during those experiments.

Data collection during the short-term experiments consisted of simultaneous field measurements of currents, sediment transport, and bathymetry to provide 


\begin{tabular}{|c|c|c|c|}
\hline No. & Date & Equipment & Comments \\
\hline \multirow[t]{2}{*}{1} & \multirow[t]{2}{*}{$\begin{array}{l}05 / 07 / 90 \text { to } \\
12 / 06 / 90\end{array}$} & $\begin{array}{l}2 \text { pods, with Puv's and } \\
\text { acoustic releases }\end{array}$ & $\begin{array}{l}\text { First pod damaged (by shrimp } \\
\text { trawler), good data. Second pod } \\
\text { not located, no data }\end{array}$ \\
\hline & & $\begin{array}{l}2 \text { thermal depth recorders } \\
\text { (TDR's) }\end{array}$ & $\begin{array}{l}\text { Not located, presumably buried, } \\
\text { no data }\end{array}$ \\
\hline 2 & $\begin{array}{l}12 / 06 / 90 \text { to } \\
07 / 17 / 91\end{array}$ & $\begin{array}{l}1 \text { pod, with Puv and } \\
\text { acoustic release }\end{array}$ & $\begin{array}{l}\text { Pod shifted (by shrimp trawler?), } \\
\text { data quality poor }\end{array}$ \\
\hline 3 & $\begin{array}{l}07 / 17 / 91 \text { to } \\
01 / 15 / 92\end{array}$ & $\begin{array}{l}1 \text { pod, with Puv and } \\
\text { acoustic release }\end{array}$ & $\begin{array}{l}\text { Puv storage disk crashed, no data } \\
\text { collected }\end{array}$ \\
\hline \multirow[t]{2}{*}{4} & \multirow[t]{2}{*}{$\begin{array}{l}01 / 15 / 92 \text { to } \\
05 / 14 / 92\end{array}$} & $\begin{array}{l}1 \text { pod, with Puv and } \\
\text { acoustic release }\end{array}$ & $\begin{array}{l}\text { Pressure data good, current meter } \\
\text { failure }\end{array}$ \\
\hline & & $\begin{array}{l}1 \text { pod, with DWG and } \\
\text { acoustic release }\end{array}$ & Data good \\
\hline \multirow[t]{2}{*}{5} & \multirow[t]{2}{*}{$\begin{array}{l}05 / 14 / 92 \text { to } \\
12 / 16 / 92\end{array}$} & $\begin{array}{l}1 \text { pod, with Puv and } \\
\text { acoustic release }\end{array}$ & $\begin{array}{l}\text { Data good through early } \\
\text { September }\end{array}$ \\
\hline & & $\begin{array}{l}1 \text { pod, with DWG and } \\
\text { acoustic release }\end{array}$ & Instrument failure, no data \\
\hline \multirow[t]{2}{*}{6} & \multirow[t]{2}{*}{$\begin{array}{l}12 / 16 / 92 \text { to } \\
04 / 20 / 94\end{array}$} & $\begin{array}{l}1 \text { pod, with Puv and } \\
\text { acoustic release }\end{array}$ & Battery failure, no data \\
\hline & & $\begin{array}{l}1 \text { pod, with DWG and } \\
\text { acoustic release }\end{array}$ & Not located, no data \\
\hline
\end{tabular}

complete coverage of the project area. Field equipment to take those measurements consisted of the following:

a. An instrumented platform and two sleds deployed in the surf zone to measure currents and sediment concentration.

b. An Acoustic Doppler Current Profiler (ADCP), and a Puv-mounted ECM to measure current velocities and sediment flux in the mouth of the Colorado River.

c. Standard and newly developed fiber optic backscatter sensors (FOBS) to measure suspended sediment concentrations close to the seabed in the surf zone.

Platform and sleds. One platform and two sleds containing similar sensors were designed to take sediment transport rate measurements. The platform was designed for shallower water (maximum depth of about $1 \mathrm{~m}$ ), and was carried to its deployment location by the field team. The sleds were designed for deeper depths, though still within (or near) the surf zone, and were moved into position using a cable attached to an anchor/pulley system. This allowed a truck on the beach to move them to either shallower or deeper locations. 


\begin{tabular}{|c|c|c|c|}
\hline \multicolumn{4}{|c|}{$\begin{array}{l}\text { Table } 2 \\
\text { Wave Data Availability }\end{array}$} \\
\hline \multirow{2}{*}{ Month } & \multicolumn{3}{|c|}{ Number of Data Records } \\
\hline & 1990 & 1991 & 1992 \\
\hline January & & $248^{2}$ & $485^{4}$ \\
\hline February & & $224^{2}$ & $696^{4}$ \\
\hline March & & $248^{2}$ & $744^{4}$ \\
\hline April & & $240^{2}$ & $720^{4}$ \\
\hline \multirow[t]{2}{*}{ May } & \multirow[t]{2}{*}{$194^{\prime}$} & \multirow[t]{2}{*}{$248^{2}$} & $307^{4}$ \\
\hline & & & $139^{5}$ \\
\hline June & $237^{1}$ & $240^{2}$ & $240^{5}$ \\
\hline July & $245^{1}$ & $171^{2}$ & $248^{5}$ \\
\hline August & $243^{1}$ & & $248^{5}$ \\
\hline September & $237^{1}$ & & $53^{5}$ \\
\hline October & $248^{1}$ & & \\
\hline November & $240^{\prime}$ & & \\
\hline \multirow[t]{2}{*}{ December } & $46^{\prime}$ & & \\
\hline & $207^{2}$ & & \\
\hline \multicolumn{4}{|c|}{$\begin{array}{l}1 \text { Deployment No. 1, Puv, 3-hr records. } \\
2 \text { Deployment No. 2, Puv, 3-hr records, lower quality data. } \\
4 \text { Deployment No. 4, DWG, } 1 \text {-hr records. } \\
5 \text { Deployment No. 5, Puv, 3-hr records. }\end{array}$} \\
\hline
\end{tabular}

During the first short-term experiment in May 1990, one platform was deployed, containing the following instrumentation (Figure 4):

a. Vertical stack of optical backscatter sensors (OBS's) to measure the vertical distribution of sediment concentration.

$b$. Vertical stack of ECM's to measure the vertical distribution of cross-shore and long-shore water velocities.

c. Acoustic sonar altimeter to measure the distance to the seabed.

d. SETRA strain-gage-type pressure sensor to measure the water level elevations.

e. Electronic compass to determine the platform orientation.

$f$. Temperature sensor used in calibration of other instruments.

g. Serial asynchronous unit (SAU) data collection system.

The OBS's measure sediment concentration in the immediate vicinity of the sensor head by measuring the backscatter intensity of an optical signal. Each OBS was calibrated at CERC in a flowtank both prior to and following each 


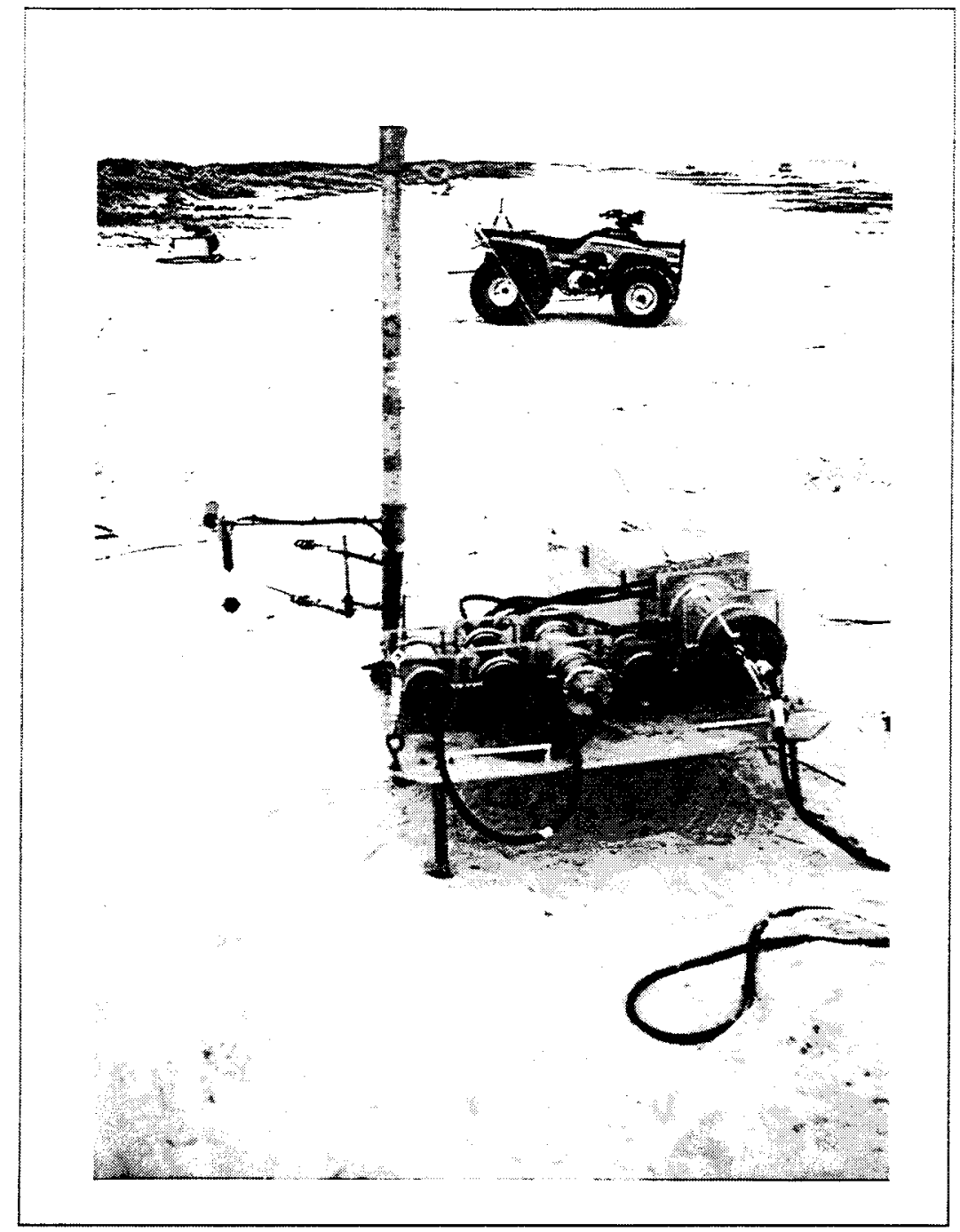

Figure 4. Instrumented platform (photo by T. E. White)

experiment. The calibrations covered a wide range of flow conditions and used sediment obtained from the Colorado River project site. These calibrations provided gain, offset, and trend information to convert the sensor output to sediment concentrations. For a discussion of the OBS, see Downing, Sternberg, and Lister (1981). The ECM's were 2.54-cm-diameter Marsh-McBirney electromagnetic current meters that measured two components of horizontal velocity. Each ECM was calibrated prior to each experiment, and the sled compass was used to rectify the ECM output into long-shore and cross-shore components of velocity. The SAU on the platform was attached to a shore cable enabling data transmission to an instrument van located on the beach. Initially, data were logged and saved onto an onsite Vax station. In later experiments, a PC-based system was used for data collection.

Following the May 1990 experiment, it was determined that one instrumented platform did not provide the coverage desired for the project site. 
So for the July 1991 and January 1992 experiments, two sleds (referred to as Sleds 1 and 2), instrumented with equipment similar to that of the platform, were added to the monitoring program (Figure 5). The platform was deployed at various locations in the surf zone on a daily basis throughout each of the three experiments. Table 3 provides platform deployment information (i.e. dates and locations) for the 1991 and 1992 experiments. The longshore locations in Table 3 are defined later in this chapter. Sleds 1 and 2 were continuously deployed in deeper water locations for periods ranging from 3 to 6 days. Table 4 provides deployment information for Sleds 1 and 2 . Figure 2 shows the reference lines for positions within the impoundment basin.

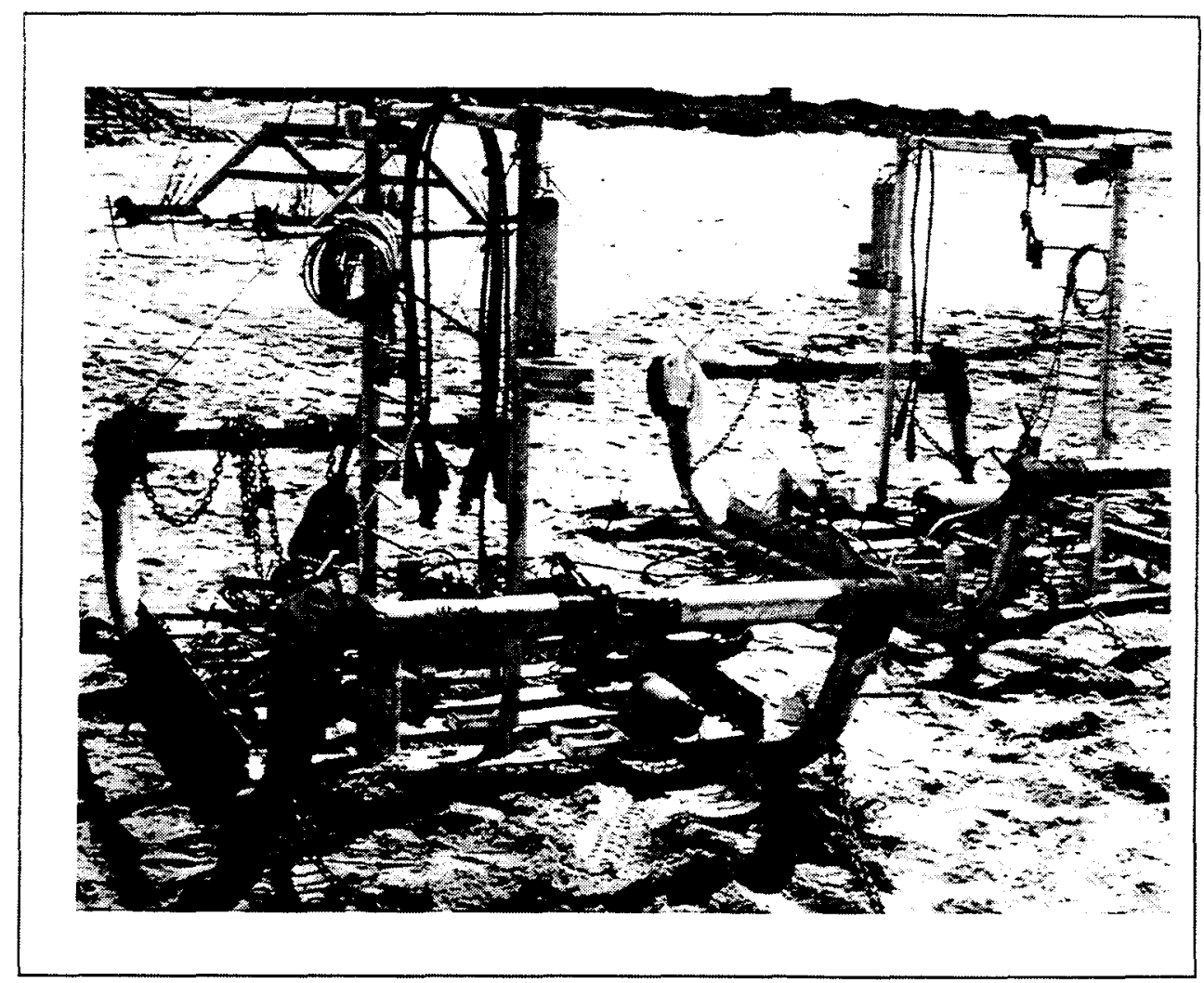

Figure 5 . Instrumented sleds (photo by T. E. White)

Acoustic Doppler Current Profiler. During the first short-term experiment, a 1,200-kHz narrow-band ADCP was deployed in the Colorado River mouth (see Figure 3). The ADCP consists of four transducers arranged on one sensor. The transducers were oriented $30 \mathrm{deg}$ relative to the vertical, at 90-deg azimuth intervals and when deployed, transmitted short acoustic pulses along narrow beams at a fixed frequency. Sound was returned (backscatter) to the transducers along the beams from small particles (scatterers) such as 


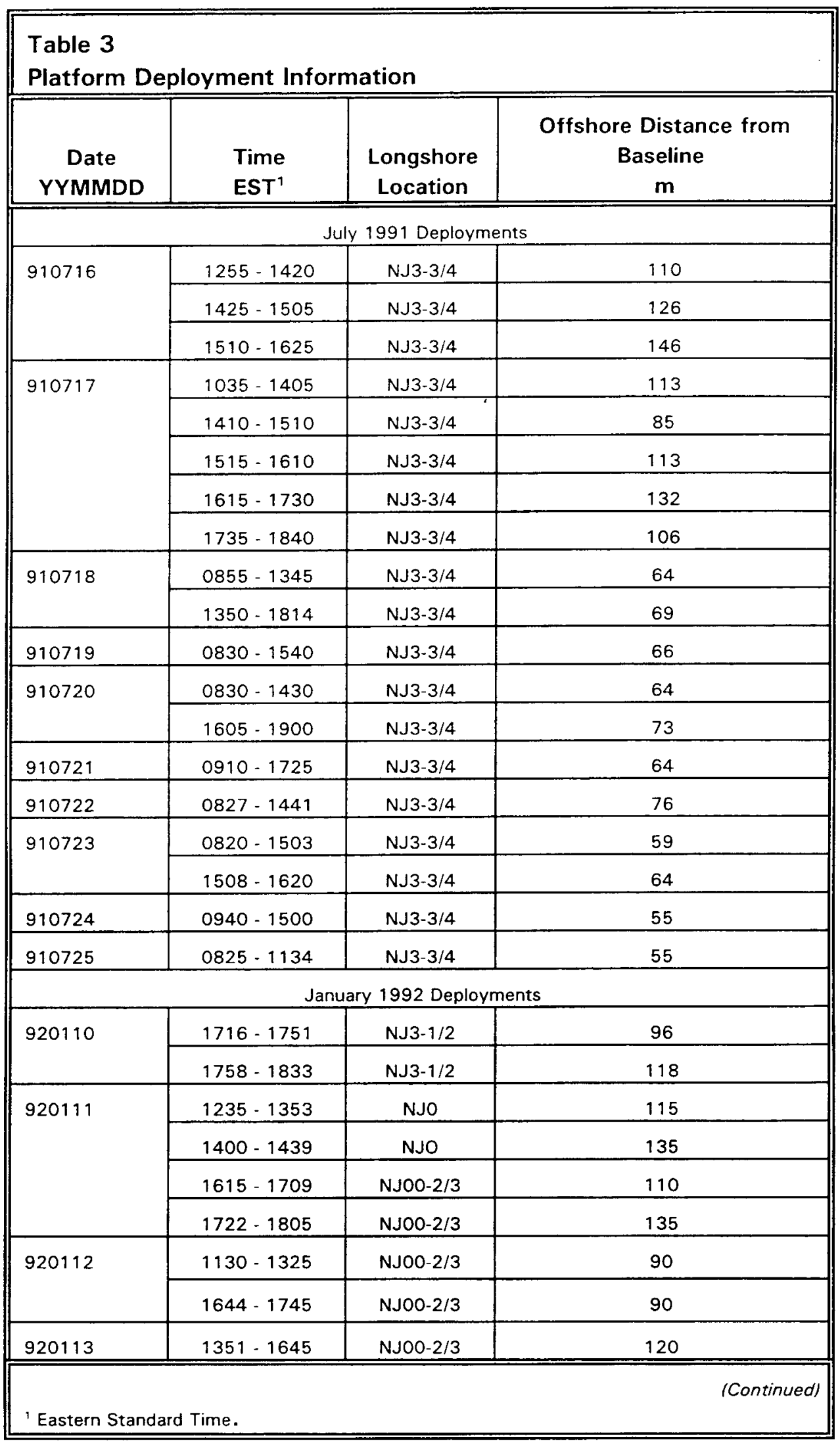




\begin{tabular}{|c|c|c|c|}
\hline $\begin{array}{c}\text { Date } \\
\text { YYMMDD }\end{array}$ & $\begin{array}{l}\text { Time } \\
\text { EST }^{1}\end{array}$ & $\begin{array}{c}\text { Longshore } \\
\text { Location }\end{array}$ & $\begin{array}{c}\text { Offshore Distance from } \\
\text { Baseline } \\
m\end{array}$ \\
\hline 920116 & $1450-1821$ & $\mathrm{NJOO}-2 / 3$ & 110 \\
\hline \multirow[t]{6}{*}{920117} & $1206-1228$ & \multirow[t]{6}{*}{ NJOO-2/3 } & 120 \\
\hline & $1229-1255$ & & 120 \\
\hline & $1256-1312$ & & 120 \\
\hline & $1322-1540$ & & 90 \\
\hline & $1545-1610$ & & 90 \\
\hline & $1625-1651$ & & 90 \\
\hline \multirow[t]{2}{*}{920118} & $0955-1030$ & NJoO-2/3 & \\
\hline & $1037-1117$ & NJOO-2/3 & \\
\hline
\end{tabular}

\begin{tabular}{|c|c|c|}
\hline \multicolumn{3}{|c|}{$\begin{array}{l}\text { Table } 4 \\
\text { Sled Locations }\end{array}$} \\
\hline Sled Number & Deployment Dates & Location \\
\hline \multirow[t]{2}{*}{1 Breaker line } & July $20-25,1991$ & $87 \mathrm{~m}$ from $\mathrm{NJO}$ \\
\hline & January $13-18,1992$ & $140 \mathrm{~m}$ from NJO \\
\hline \multirow{2}{*}{$\begin{array}{l}2 \text { Impoundment } \\
\text { Basin }\end{array}$} & July $21-25,1991$ & $134 \mathrm{~m}$ from $33+900$ \\
\hline & January $16-18,1992$ & $171 \mathrm{~m}$ from $34+000$ \\
\hline
\end{tabular}

suspended sediment or biological matter. The return signals were processed to yield three-dimensional (3-D) velocities for the scatterers, which have been shown to be an excellent approximation to the current velocity.

The ADCP was deployed in a mount on the river bottom in approximately $5 \mathrm{~m}$ of water. The transducers were placed pointing upward to continuously collect 3-D velocity vectors and backscatter intensities to obtain current profiles in the water column and estimate sediment flux in the river mouth, respectively. Figure 6 is a photograph of the ADCP in the mount prior to deployment. An ECM on a pod was also deployed to obtain current information within the bottom meter of the water column. 


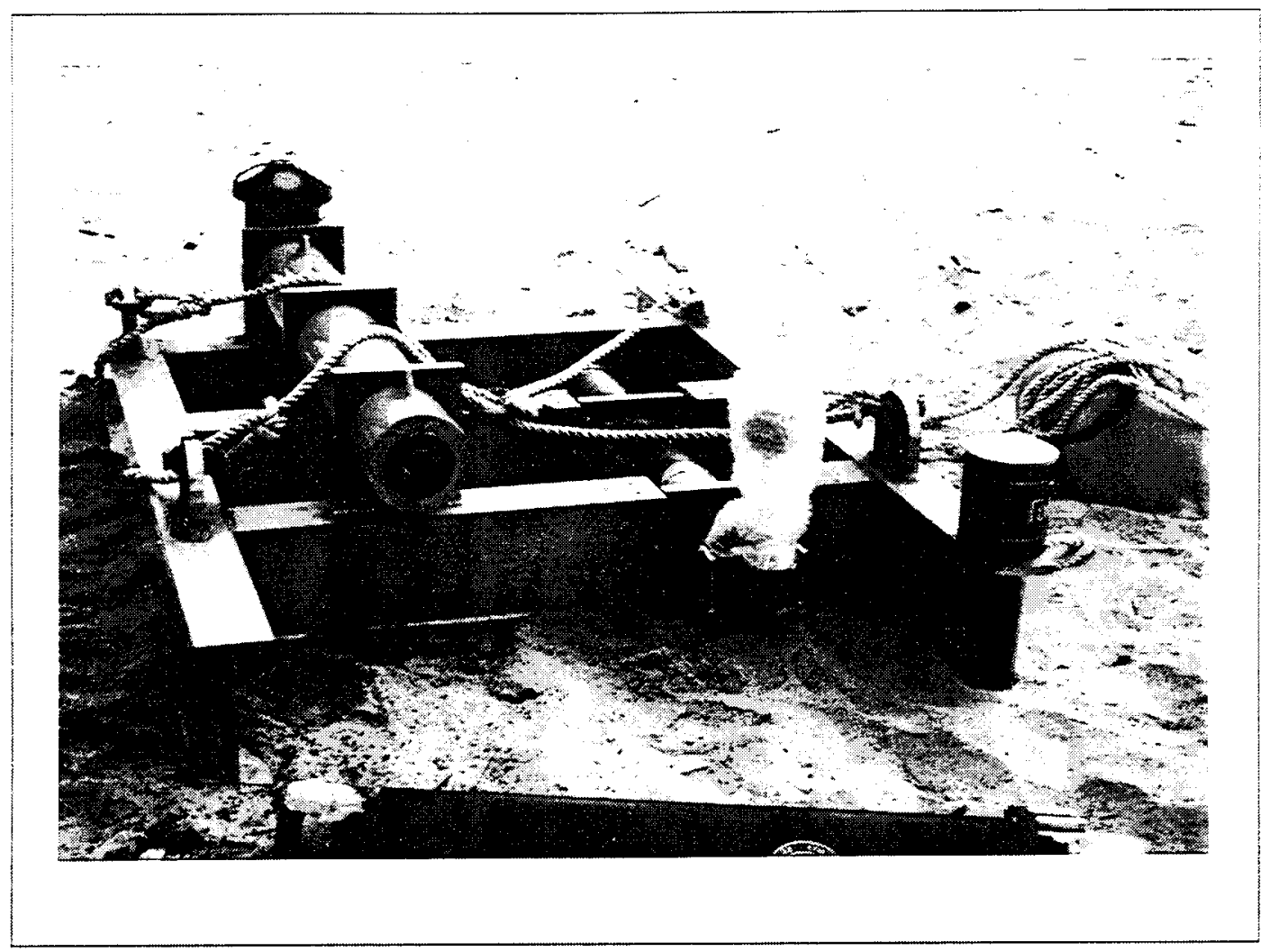

Figure 6. ADCP deployed in equipment mount (photo by T. E. White)

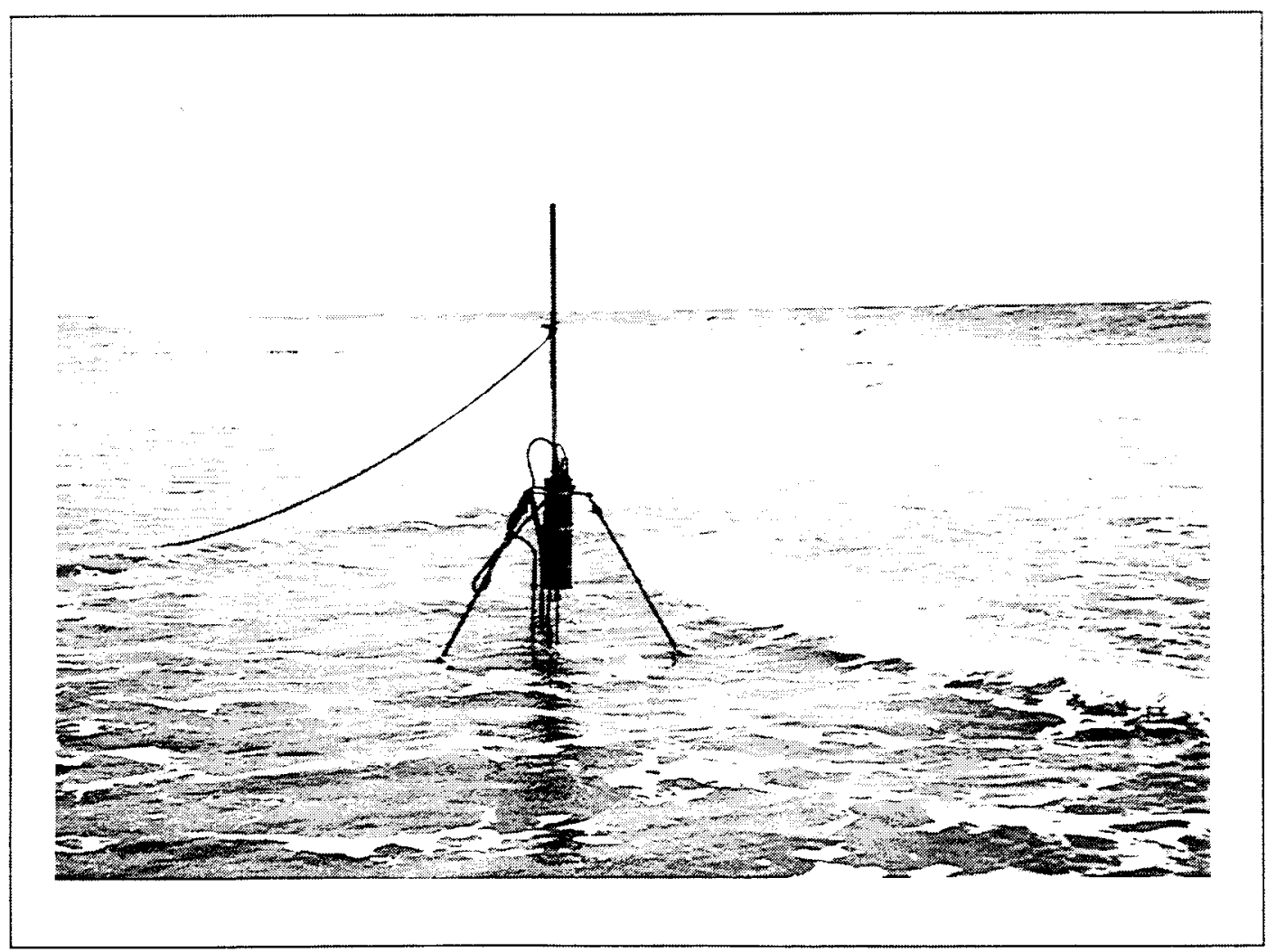

Figure 7. FOBS-instrumented tripod (photo by T. E. White) 
Suspended sediment measurements near the seabed. A newly developed FOBS was also deployed at Colorado River during the three short-term experiments, as shown in Figure 7. This sensor package contained a stack of miniaturized OBS's which could be deployed at the seabed level to measure bedload or near-bedload sediment concentrations, as described in Beach, Sternberg, and Johnson (1992). The sensors measured sediment concentrations at five elevations within the bottom $6 \mathrm{~cm}$ of the water column, and were deployed on each of two small, mobile tripods (Kraus, Gingerich, and Rosati 1989). These tripods also held a standard OBS higher in the water column, a 4-cm near-bed ducted-impeller current meter, and one tripod also had a strain gage pressure transducer.

Prior to deployment, the sensors on the tripod were tested for functionality. The tripods were carried out to the designated position in the surf and the legs were forced into the sand to anchor the tripod. Sensor output was transmitted through a shore cable to a data logger located inside the WES instrument van, and was recorded on a hard disk for periods up to $130 \mathrm{~min}$ duration. The shore cable was attached to a vertical pole located approximately $5 \mathrm{~m}$ inshore as a strain relief. The tripods were frequently inspected to confirm and maintain proper sensor orientations and elevation above the bed. Data runs coincided with WES sled and platform runs. Figure 8 shows the deployed tripods along with the WES platform (which is mostly underwater) in the surf zone. Typically, tripod locations were not changed during a day. More information on the deployment of this instrumentation is found in Beach (1995).

Table 5 gives deployment dates and locations. The depth column gives the depth of the bottom of the FOBS sensor, which was essentially the sediment depth below the mean water surface, as determined by the pressure transducer. Since only tripod A had a pressure transducer, only some estimated depth values are given for tripod B. Each tripod also held only one ducted-impeller current meter; thus each could only measure one component (cross-shore or longshore) of velocity.

Other measurements. Sediment samples (grab samples) were obtained at the site on October 18, 1989 and February 11, 1994. Aerial photographs were obtained during the first experiment on 3 and 5 May, 1990. Other aerial photographs were obtained from SWG files and from the National Aeronautic and Space Administration. During the first experiment, a surf zone pressure cable was deployed, as shown in Figure 3. This new instrument consisted of 10 strain gage pressure sensors imbedded within an approximately 23 -m-long cable which was stretched across the surf zone. The instrumented cable performed satisfactorily when transmitting power and collecting data. However, it was determined that pressure sensors mounted on the platform and sleds supplied sufficient surf zone wave information to satisfy the mission requirements, so the cable was not used during the later experiments. 


\begin{tabular}{|c|c|c|c|c|}
\hline \multicolumn{5}{|c|}{$\begin{array}{l}\text { Table } 5 \\
\text { FOBS Tripod Deployment Information } \\
\text { (from Beach 1995) }\end{array}$} \\
\hline $\begin{array}{l}\text { Date } \\
\text { YYMMDD } \\
\end{array}$ & $\begin{array}{l}\text { Time of } \\
\text { Deployment }\end{array}$ & Tripod & $\begin{array}{l}\text { Offshore } \\
\text { Location }\end{array}$ & $\begin{array}{c}\text { Depth } \\
\mathbf{c m} \\
\end{array}$ \\
\hline 900502 & 1420 & $\mathrm{~B}$ & $M^{1}$ & $(75)^{2}$ \\
\hline 900504 & 1310 & $B$ & $M$ & (75) \\
\hline 900504 & 1455 & $B$ & $s$ & (15) \\
\hline 900504 & 1624 & B & $s$ & (15) \\
\hline 900505 & 1130 & B & 1 & (55) \\
\hline 900505 & 1300 & B & $M$ & (75) \\
\hline 910719 & 1243 & B & 0 & $(100)$ \\
\hline 910720 & 1345 & A & 1 & 25.8 \\
\hline 910720 & 1345 & B & 1 & (15) \\
\hline 910720 & 1610 & $\mathrm{~A}$ & 0 & 52.6 \\
\hline 910720 & 1610 & $B$ & $M$ & \\
\hline 910720 & 1758 & A & $M$ & 44.5 \\
\hline 910720 & 1758 & B & 1 & \\
\hline 910721 & 0955 & A & 1 & 24.0 \\
\hline 910721 & 0955 & $B$ & $M$ & \\
\hline 910721 & 1330 & A & 1 & 23.2 \\
\hline 910721 & 1330 & B & $M$ & \\
\hline 910721 & 1555 & A & 1 & 22.0 \\
\hline 910721 & 1555 & B & $M$ & \\
\hline 910722 & 0915 & A & 1 & 31.0 \\
\hline 910722 & 0915 & B & $M$ & \\
\hline 910722 & 1120 & A & 1 & 31.3 \\
\hline 910722 & 1120 & B & $M$ & \\
\hline 910723 & 1100 & A & $\mathrm{M}$ & 35.5 \\
\hline 910723 & 1100 & $\mathrm{~B}$ & 1 & \\
\hline \multicolumn{5}{|r|}{ (Continued) } \\
\hline \multicolumn{5}{|c|}{$\begin{array}{l}\text { 'Deployments made in the outer, inner, and mid-surf zones are designated as } O, 1 \text {, } \\
\text { and } M \text {, respectively. Other sites are designated as the swash zone (S), longshore } \\
\text { trough }(T) \text {, and bar crest (B). } \\
2 \text { Depths listed in parentheses are estimated. }\end{array}$} \\
\hline
\end{tabular}




\begin{tabular}{|c|c|c|c|c|}
\hline $\begin{array}{c}\text { Date } \\
\text { YYMMDD }\end{array}$ & $\begin{array}{c}\text { Time of } \\
\text { Deployment }\end{array}$ & Tripod & Location & $\begin{array}{c}\text { Depth } \\
\mathrm{cm}\end{array}$ \\
\hline 910723 & 1340 & $A$ & $M$ & 37.0 \\
\hline 910723 & 1340 & $B$ & 1 & 37.0 \\
\hline 910724 & 1025 & $\mathrm{~A}$ & $M$ & 34.9 \\
\hline 910724 & 1025 & B & 1 & \\
\hline 910724 & 1130 & A & $\mathrm{M}$ & 32.8 \\
\hline 910724 & 1130 & B & 1 & \\
\hline 910724 & 1347 & $\mathrm{~A}$ & M & 25.9 \\
\hline 910724 & 1347 & $B$ & $M$ & \\
\hline 910725 & 0850 & $A$ & $\mathrm{M}$ & 42.2 \\
\hline 910725 & 0850 & B & 1 & \\
\hline 910725 & 1058 & $A$ & $\mathrm{M}$ & 39.0 \\
\hline 910725 & 1058 & B & 1 & \\
\hline 920112 & 1611 & A & $T$ & 159.2 \\
\hline 920112 & 1611 & $\mathrm{~B}$ & B & \\
\hline 920113 & 1351 & A & B & 78.8 \\
\hline 920113 & 1351 & B & $T$ & \\
\hline 920113 & 1556 & A & B & 86.5 \\
\hline 920113 & 1556 & B & $T$ & \\
\hline 920116 & 1255 & $\mathrm{~A}$ & $\mathrm{~B}$ & 140.9 \\
\hline 920116 & 1255 & B & $T$ & \\
\hline
\end{tabular}

\section{Profile measurements}

Nearshore beach profiles. Beach profiles at the mouth of the Colorado River were initially surveyed by SWG in 1984 . Surveying was conducted during May and December 1990 by this monitoring program to reestablish the earlier benchmarks, and to survey baseline and vertical and horizontal control lines along the beach northeast and southwest of the jetties. The survey baselines and benchmarks were reestablished using an Omni-1 Total Station equipped with an electronic measuring device to measure distance, angles, and elevations. 


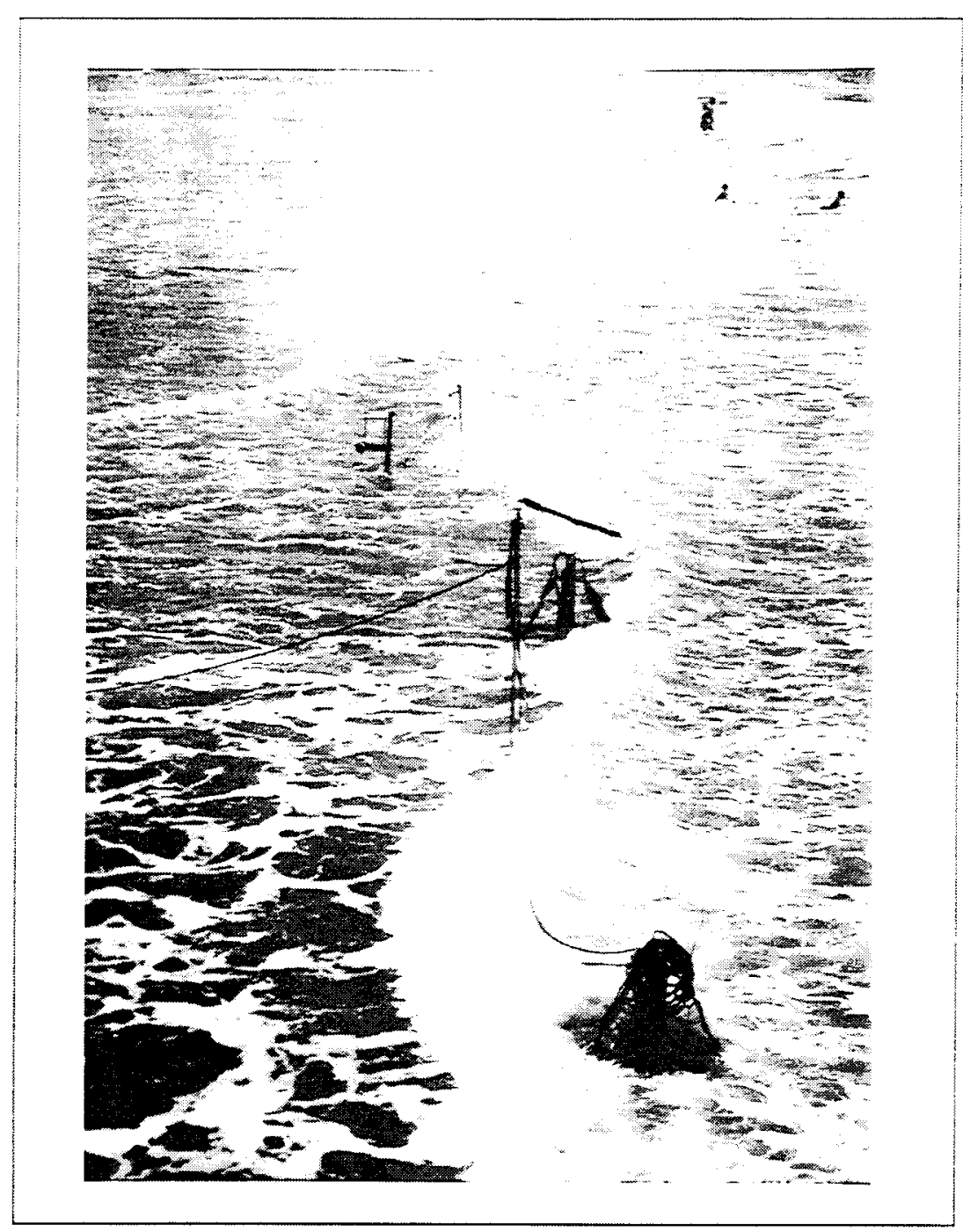

Figure 8. FOBS-instrumented tripods deployed with WES platform (located in upper left) (photo by T. E. White)

Survey profiles both northeast and southwest of the jetties were taken during the December 1990 profiling trip, and the July 1991 and January 1992 experiments for subsequent calculation of volumetric change (erosion and accretion) along the beach. Locations of the survey lines are provided in Figure 9. During the January 1992 experiment, daily surveys were conducted on profile lines $\mathrm{NJ} 00-2 / 3, \mathrm{NJO}-1 / 3$, and $\mathrm{NJ} 0$. Table 6 provides the survey lines and data availability.

Survey lines followed those established by SWG in 1984. North and south of the inlet, the baseline corresponded approximately to the line of the dune crest, which was approximately $100 \mathrm{~m}$ landward of the shoreline. Most range 


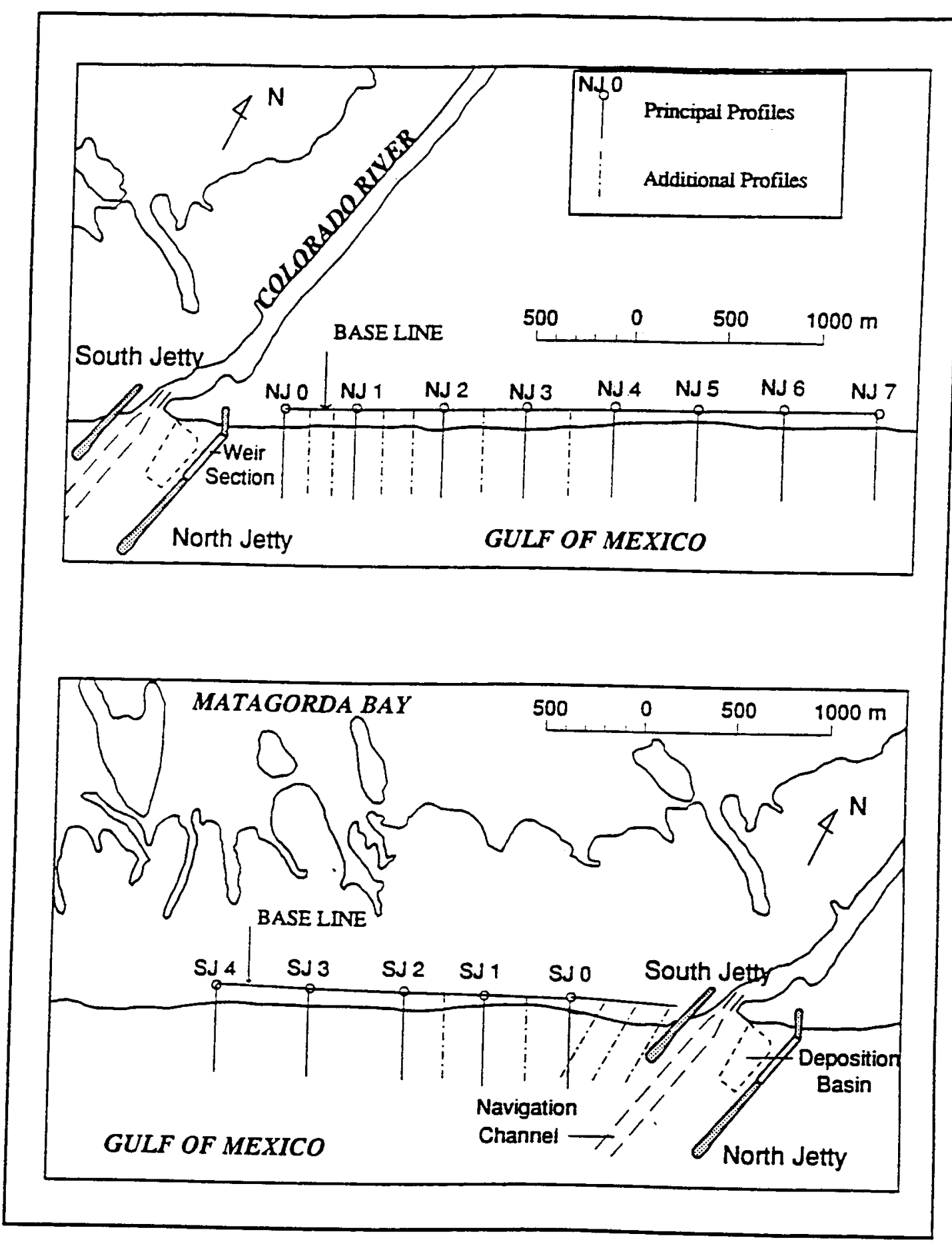

Figure 9. Survey line locations (from Liang 1995) 


\begin{tabular}{|c|c|c|c|c|}
\hline \multicolumn{5}{|c|}{$\begin{array}{l}\text { Table } 6 \\
\text { Nearshore Beach Profiles (from Liang 1995) }\end{array}$} \\
\hline $\begin{array}{l}\text { Profile } \\
\text { Number }\end{array}$ & $\begin{array}{c}\text { Location } \\
\mathrm{m}^{1}\end{array}$ & $\begin{array}{c}\text { December } \\
1990\end{array}$ & $\begin{array}{c}\text { July } \\
1991 \\
\end{array}$ & $\begin{array}{c}\text { January } \\
1992 \\
\end{array}$ \\
\hline \multicolumn{5}{|c|}{ North of Jetties } \\
\hline NJO & $0.0^{2}$ & $35-770^{4}$ & $0-425$ & 0.160 \\
\hline $\mathrm{NJO}+1 / 3$ & 117.9 & $90-780$ & $10-390$ & $10-150$ \\
\hline $\mathrm{NJO}+2 / 3$ & 235.7 & $90-765$ & $40-450$ & $10 \cdot 150$ \\
\hline NJ1 & 353.6 & $90-760$ & $15-400$ & 0.840 \\
\hline $\mathrm{NJ} 1+1 / 3$ & 506.0 & $5-700$ & $15-90$ & $5-850$ \\
\hline $\mathrm{NJ1}+2 / 3$ & 658.4 & $0-665$ & $10-85$ & $10-840$ \\
\hline NJ2 & 810.8 & 0.665 & 0.85 & $10-870$ \\
\hline $\mathrm{NJ} 2+1 / 2$ & $1,139.9$ & $20-650$ & $25-75$ & $0-840$ \\
\hline NJ3 & $1,268.0$ & 0.730 & 0.90 & $0-865$ \\
\hline $\mathrm{NJ} 3+1 / 2$ & $1,497.1$ & $75 \cdot 710$ & $15-85$ & $40-820$ \\
\hline NJ4 & $1,725.2$ & 0.690 & $0-75$ & $10-865$ \\
\hline NJ5 & $2,182.4$ & $70-740$ & $0-70$ & 0.795 \\
\hline NJ6 & $2,639.6$ & $\ldots$ & $25 \cdot 75$ & $30-840$ \\
\hline N.7 & $3,096.8$ & $15 \cdot 775$ & $0-90$ & 0.795 \\
\hline \multicolumn{5}{|c|}{ South of Jetties } \\
\hline SJOO & $-457.2^{3}$ & --- & $175-240$ & 0.260 \\
\hline $\mathrm{SJOO}+1 / 3$ & -304.8 & $\cdots$ & $50-230$ & $45-250$ \\
\hline $5100+2 / 3$ & -152.4 & $\cdots$ & $80-225$ & $80-225$ \\
\hline SJO & 0.0 & --- & $75-200$ & $0-160$ \\
\hline $\mathrm{SJO}+1 / 2$ & +228.6 & $-\cdots$ & $75-220$ & $0-160$ \\
\hline SJ1 & +457.2 & $\cdots$ & $40-210$ & 0.160 \\
\hline $\mathrm{SJ} 2$ & +914.4 & $\ldots$ & $50-200$ & --- \\
\hline $\mathrm{SJ} 3$ & $+1,371.6$ & $\ldots$ & $0-180$ & -- \\
\hline SJ4 & $+1,828.8$ & $\ldots$ & $40-160$ & $\ldots$ \\
\hline \multicolumn{5}{|c|}{$\begin{array}{l}\text { All units are in meters. } \\
2 \text { Longshore distance (northeastward) from NJO profile line. } \\
3 \text { Longshore distance from SJO profile line; negative values are closer to the jetties than } \\
\text { SJO. } \\
4 \text { Survey range, first number is distance from the baseline to the inland end and the second } \\
\text { number is the distance of the offshore end of a profile line. }\end{array}$} \\
\hline
\end{tabular}


lines were perpendicular to this baseline except $\mathrm{SJ} 00, \mathrm{SJ} 00+1 / 3$, and SJ00 $+2 / 3$, which were at $60-\mathrm{deg}$ angles from the baseline. Range line NJ00 was at the northeast jetty. NJ0 was $308 \mathrm{~m}$ from NJ00, and NJ1 was $353.2 \mathrm{~m}$ from NJ0. The other northern principal range lines (NJ1-NJ7) were $457.2 \mathrm{~m}$ apart. Range line SJ00 was near the southwest jetty. All of the southern principal range lines (SJ00-SJ4) were $457.2 \mathrm{~m}$ apart. Intermediate range lines were labeled as $x J y+1 / 4, x J y+1 / 3, x J y+1 / 2, x J y+2 / 3$, or $x J y+3 / 4$ (where $x$ was $\mathrm{N}$ or $\mathrm{S}$, and $\mathrm{y}$ was 00 through 7) and were that fractional distance between the principal range lines. Longshore distances in this report are the distances from $\mathrm{NJO}$ and $\mathrm{SJO}$, with positive values heading away from the jetties.

The nearshore beach surveys were accomplished using a commercially available auto-tracking infrared geodimeter. The geodimeter targeted a prism hand-carried by a rod carrier on the beach who waded into shallower water depths. For measurements further offshore in deeper water, the prism was attached to the top of a survey rod (approximately $6 \mathrm{~m}$ in height) mounted on a sled. Figure 10 shows the rod setup. The survey sled was attached to a cable, dragged offshore by a boat along the survey line and pulled inland with 4-wheel-drive vehicles. Sled surveying was limited to low-wave conditions.

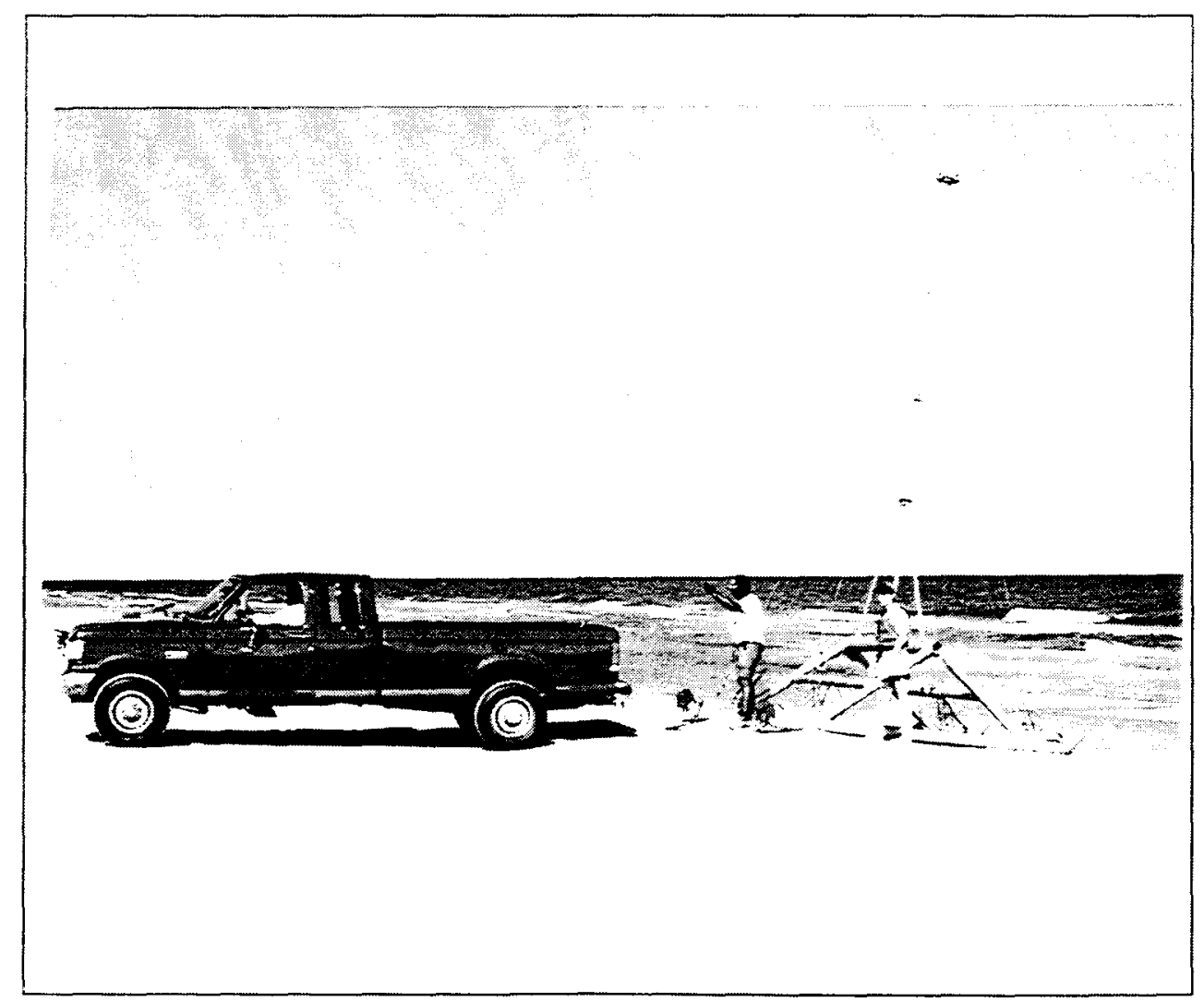

Figure 10. Rod setup for offshore geodimeter surveying (photo by T. E. White) 


\section{SWG data}

The Galveston District did extensive surveys of the impoundment basin in the time period 1990 to 1992 . Available impoundment basin surveys are given in Table 7 and their locations are shown in Figure 2. In addition, SWG supplied volumes of material dredged from the mouth of the river and the impoundment basin during the monitoring effort. These volumes are shown in Table 8. They also supplied sediment samples taken on August 18, 1994.

\begin{tabular}{|l|l|l|l|l|l|l||}
\hline \hline $\begin{array}{l}\text { Table } 7 \\
\text { Available Impoundment Basin Bathymetric Surveys (1990-1992) }\end{array}$ \\
\hline \hline \multirow{7}{*}{$\begin{array}{l}\text { Survey } \\
\text { Line } \\
\text { Number }\end{array}$} & $3 / 90$ & $5 / 90$ & $8 / 90$ & $4 / 91$ & $4 / 92$ & $9 / 92$ \\
\cline { 2 - 8 } & \multicolumn{7}{|c||}{ Survey Dates (month/year) } \\
\hline \hline $33+600$ & $x x x$ & & $x x x$ & $x x x$ & & $x x x$ \\
\hline $33+700$ & $x x x$ & & $x x x$ & & $x x x$ & \\
\hline $33+800$ & $x x x$ & & $x x x$ & $x x x$ & $x x x$ & $x x x$ \\
\hline $33+900$ & $x x x$ & $x x x$ & $x x x$ & & $x x x$ & \\
\hline $34+000$ & & $x x x$ & $x x x$ & & $x x x$ & $x x x$ \\
\hline $34+100$ & & $x x x$ & $x x x$ & & $x x x$ & \\
\hline $34+200$ & & $x x x$ & $x x x$ & $x x x$ & & $x x x$ \\
\hline
\end{tabular}

\begin{tabular}{||c|r|r|r||}
\hline \hline \multicolumn{4}{|c||}{$\begin{array}{l}\text { Table } 8 \\
\text { Dredging Volumes at the Mouth of the Colorado River }\end{array}$} \\
\hline \hline Date & $\begin{array}{c}\text { Impoundment } \\
\text { Basin } \\
\text { cubic meters }\end{array}$ & $\begin{array}{c}\text { Entrance } \\
\text { Channel } \\
\text { cubic meters }\end{array}$ & $\begin{array}{c}\text { Total } \\
\text { cubic meters }\end{array}$ \\
\hline \hline $9 / 89-3 / 90$ & 480,827 & 837,211 & $1,318,038$ \\
\hline $4 / 91-5 / 91$ & 0 & 47,464 & 47,464 \\
\hline $9 / 92-2 / 93$ & 518,547 & 536,886 & $1,055,433$ \\
\hline $12 / 93-2 / 94$ & 618,745 & 51,303 & 670,048 \\
\hline $12 / 94-2 / 95$ & 176,049 & 203,542 & 379,591 \\
\hline
\end{tabular}




\section{Data Observations and Analyses}

\section{Waves}

Seventeen months of high quality directional wave data were collected with Puv and DWG gages as described in Chapter 3, plus an additional seven months of lower quality data. Unless specifically stated, the lower quality data are not included in the discussion below. The measured wave data obtained from both sensor types were first transformed to fluctuations in sea surface elevation using a $\cosh k(z+d) / \cosh k d$ factor (where $k$ is the wave number ( $=2 \pi$ /wave length), $z$ is the (negative) sensor depth, and $d$ is the water depth). Secondly, energy-frequency-direction spectra were computed for each sampling interval using the standard methods of Longuet-Higgins, Cartwright, and Smith (1963). All wave heights in this report refer to $H_{m 0}$, calculated as four times the square root of the variance of the record. This value is essentially equivalent to the significant wave height. The peak period $\left(T_{p}\right)$ and direction $\left(D_{p}\right)$ refer to the period and direction of the maximum energy band of the spectrum. Direction is the direction the waves are coming from.

The mean (average) wave height for the entire measurement interval was $0.6 \mathrm{~m}$, and the mean peak period was $5.9 \mathrm{sec}$. Though some scatter was observed in the monthly wave data, there was a trend toward lower height and shorter period waves in the late summer and fall (August-October), as shown in Figures 11 and 12. Monthly percent occurrence of wave heights and periods are given in Appendix A, and the monthly height, period, and direction summaries of the wave data are given in Appendix B.

The highest $H_{m 0}$ in the record is $2.42 \mathrm{~m}$ on 27 November 1990 . Over the 17 -month interval of data collection, only six storms produced wave heights in excess of $2 \mathrm{~m}$. The duration of those maximum storm events was usually less than a day. This is comparable to the WES's Wave Information Study (WIS) wave hindcast information (Hubertz and Brooks 1989) from station 9 in the Gulf of Mexico. The WIS significant wave height that is exceeded $12 \mathrm{hr} /$ year is determined to be $2.5 \mathrm{~m}$, with a corresponding period of approximately $9.1 \mathrm{sec}$. 


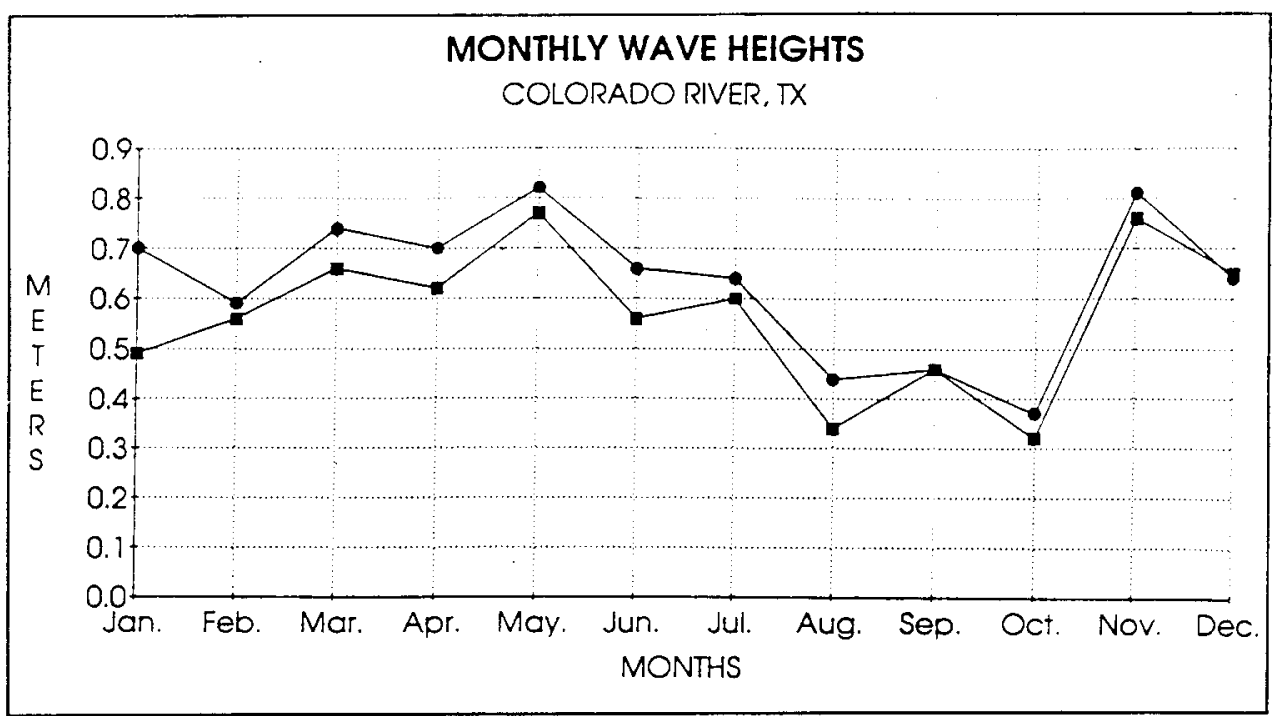

Figure 11. Mean (circles) and median (squares) monthly wave heights $\left(H_{\text {mo }}\right)$ at Colorado River, TX

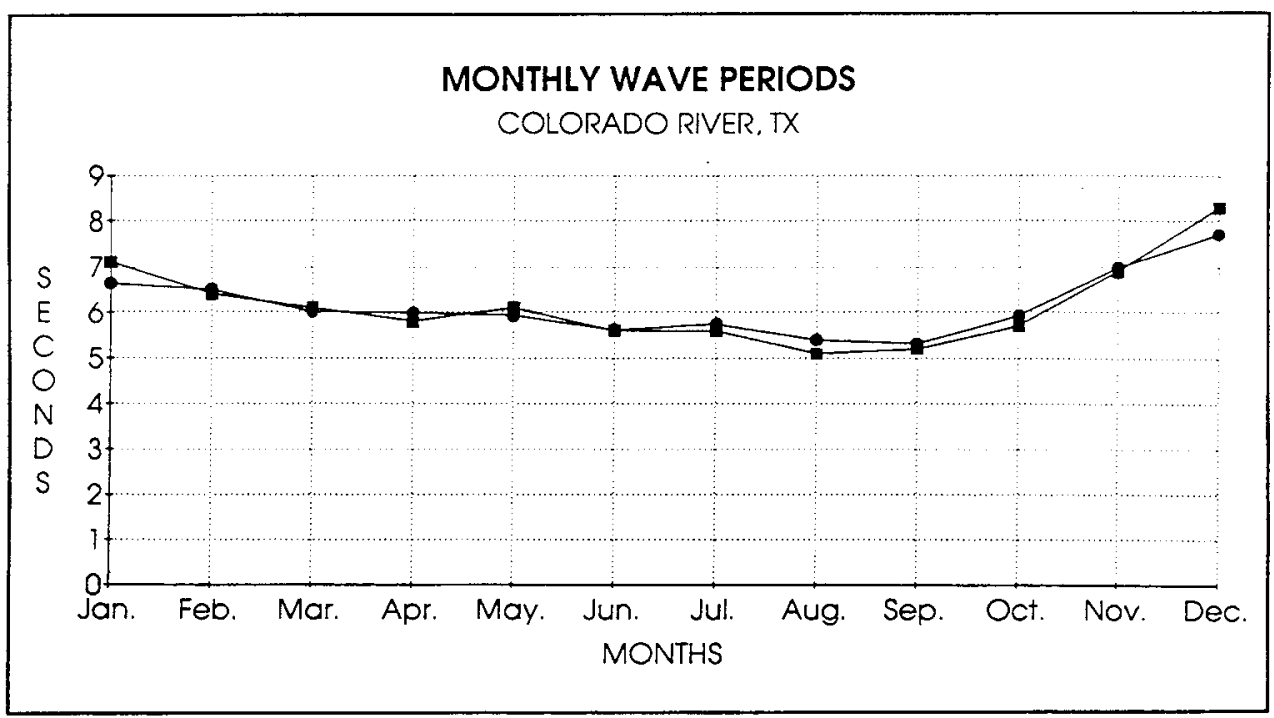

Figure 12. Mean (circles) and median (squares) monthly peak wave periods at Colorado River, TX

No hurricanes struck the Texas coast in either 1990 or 1992. The largest storms in the Gulf of Mexico those two years were: Hurricane Diana, a minimal storm, which crossed Yucatan and struck the Mexican mainland on August 8, 1990; Tropical Storm Marco, which skirted the west coast of Florida and made landfall on October 12, 1990; and Hurricane Andrew, a major storm, which struck the Louisiana coast (about $500 \mathrm{~km}$ east-northeast of Colorado River, TX) on August 26, 1992. The wave data show long-period $(14+\mathrm{sec})$ swell associated with Hurricane Andrew (the longest periods in the data set), 
but relatively low amplitude (maximum is $0.87 \mathrm{~m}$ ). Signatures of the other two hurricanes are not observable in the data set. On average, major hurricanes can be expected to strike this portion of the Texas coast about four times every 100 years (Bodine 1969). A total of about 25 major and minor hurricanes have made landfall on the Matagorda Peninsula (about $100 \mathrm{~km}$ long) in the last 150 years. Thus, occasionally, wave conditions will be substantially more extreme than are reflected in this data set.

The shore-normal direction along the coastline at the mouth of the Colorado River is approximately $155 \mathrm{deg}$. A substantially greater portion of the waves approach the coastline from the 65- to155-deg quadrant (from the left for someone standing on the beach looking offshore) than from the 155- to 245-deg quadrant, as is shown in the wave rose in Figure 13.

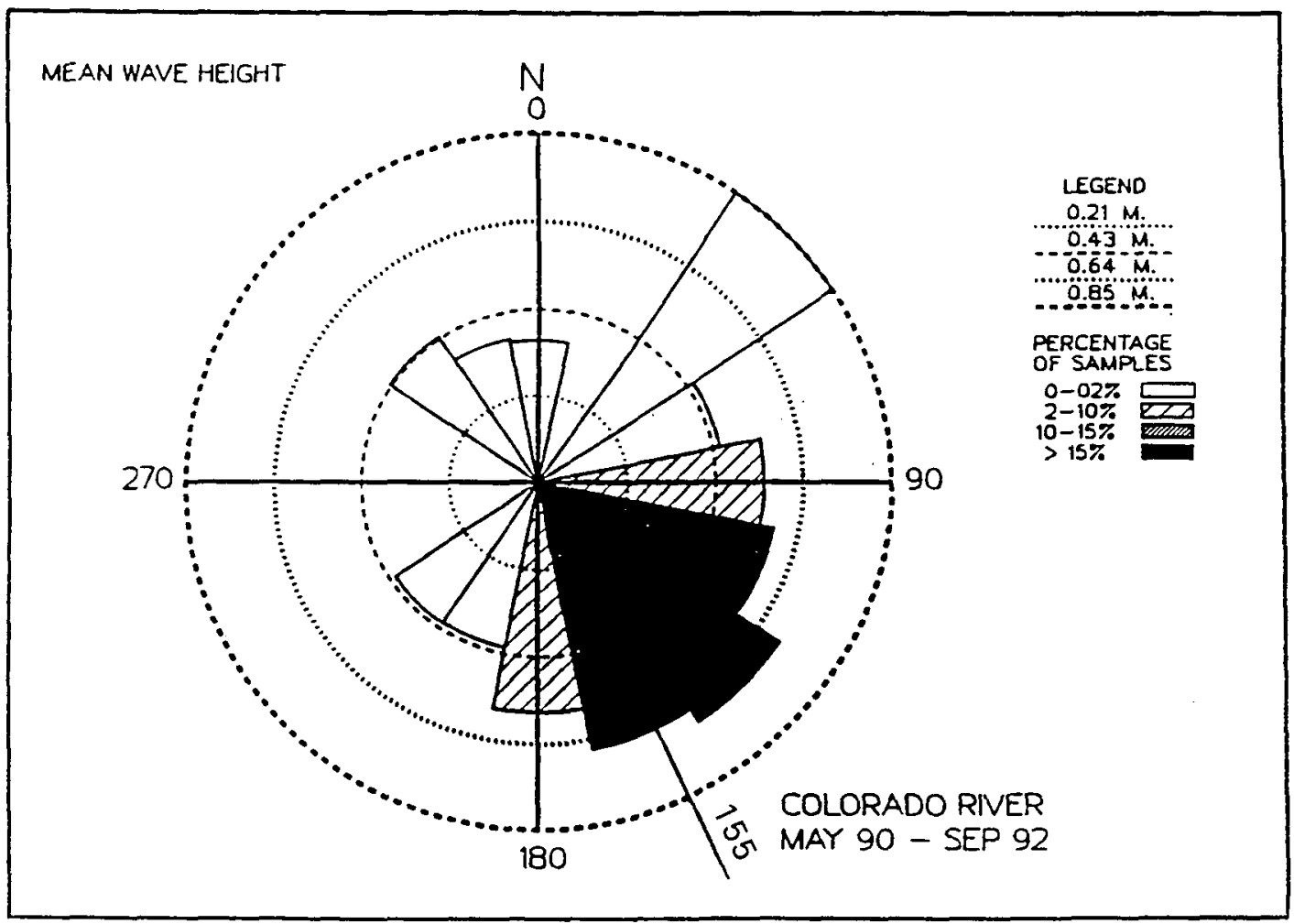

Figure 13. Wave rose for the mouth of the Colorado River, TX. The shorenormal direction is approximately $155 \mathrm{deg}$

This predominant wave direction is also seen in the angular distribution of the deepwater wave energy flux (wave power), a parameter related to the longshore sediment transport. Wave power is the energy transmitted across a vertical plane perpendicular to the direction of wave advance per unit length of wave crest. The formula, from the Shore Protection Manual (SPM 1984), is: 


$$
P=\frac{\rho g H_{0}{ }^{2} n C}{8}
$$

where:

$$
\begin{aligned}
& P=\text { wave power } \\
& \rho=\text { water density } \\
& g=\text { acceleration of gravity } \\
& H_{0}=\text { deepwater wave height } \\
& n=0.5 \\
& C=\text { wave phase speed }
\end{aligned}
$$

The directional spread of this flux calculated from the 17-month wave data record at Colorado River is shown in Figure 14. The energy flux has been divided into 15 -deg bins relative to the shore-normal direction (155 deg). Negative angles show the energy coming from easterly directions (Louisiana) and positive angles show the energy coming from southerly directions (Mexico). Clearly a large majority of the wave energy approaches the coast from an easterly direction, which makes the net longshore sediment transport to the southwest (toward Mexico).

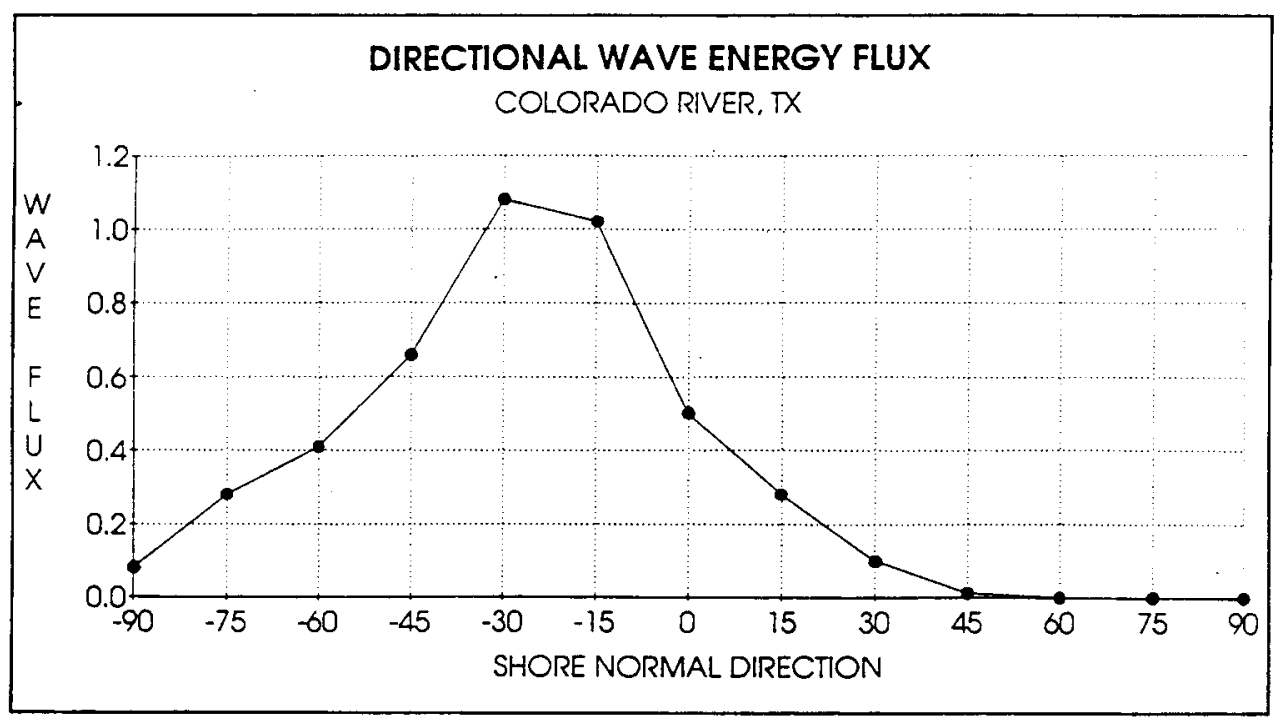

Figure 14. Directional distribution of wave energy flux in kilowatts per meter of crest length

\section{Surf Zone Sediment Transport Measurements}

Sediment concentrations at points within the surf zone were measured using stacks of OBS's and ECM's mounted on a platform and two sleds during the surf zone experiments as described in Chapter 3. Examples of the OBS 
sediment concentration and ECM velocity data are shown in Figures 15 and 16, respectively, for a run starting at 1504 hours on 16 January 1992. In Figure 16 the $\mathrm{V}$ velocity (upper plot) is in the longshore direction; $\mathrm{U}$ velocity is cross-shore. This sensor was at an elevation of $17.5 \mathrm{~cm}$ above the bed.

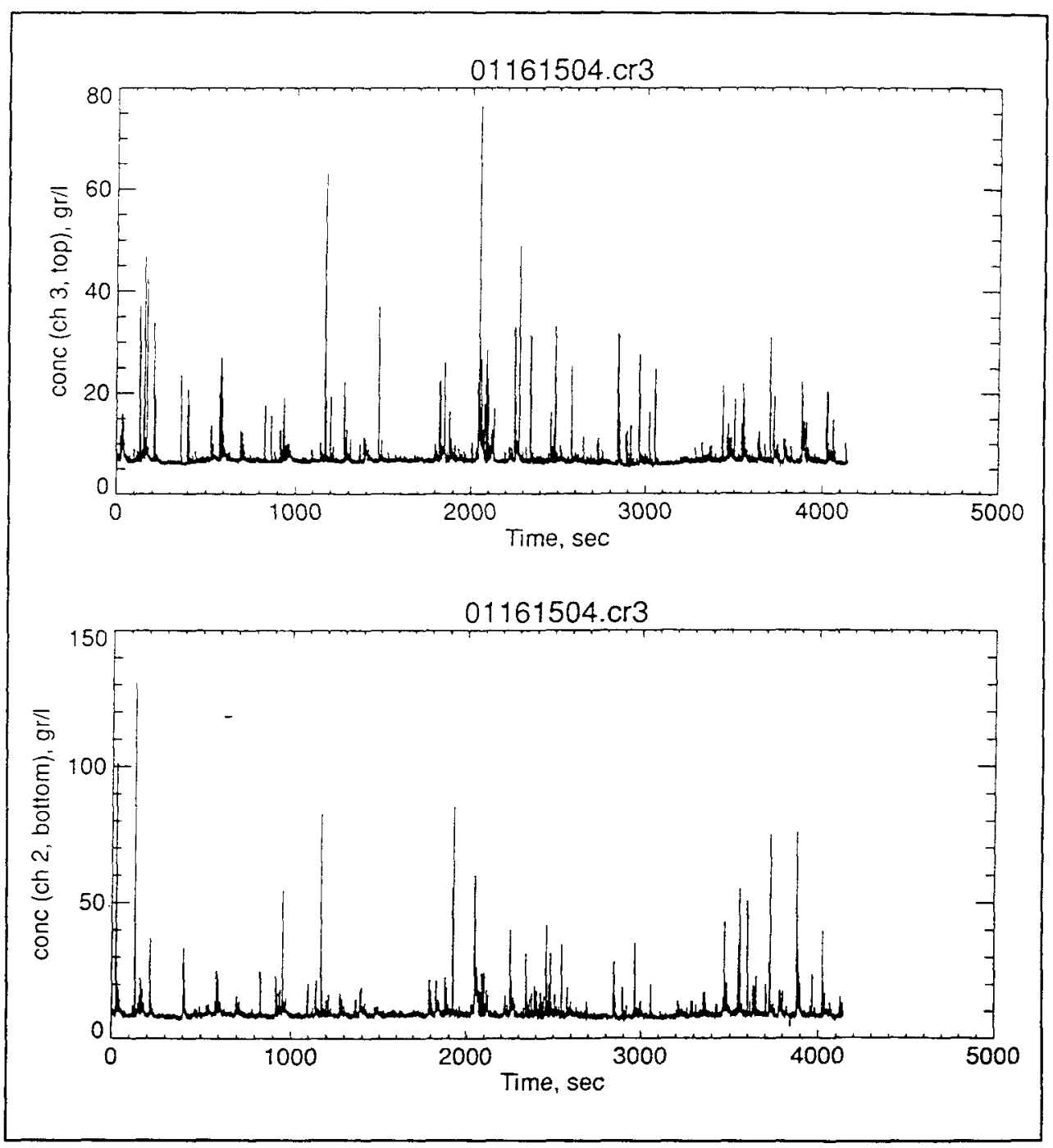

Figure 15. Example of platform OBS output on 16 January 1992. Top and bottom sensors are 27.5 and $12.5 \mathrm{~cm}$ above the bed, respectively (from White1992)

The concentrations, velocities, bottom location, and surface location data were combined, as shown in Figure 17, to produce a vertically integrated sediment transport rate value for each 0.2 -sec time-step in the data record. In Figure $17, c=$ concentration, $v=$ long-shore velocity, and $z=$ vertical distance. These values were then averaged to produce transport rate values provided in Appendix C, Table C1. 


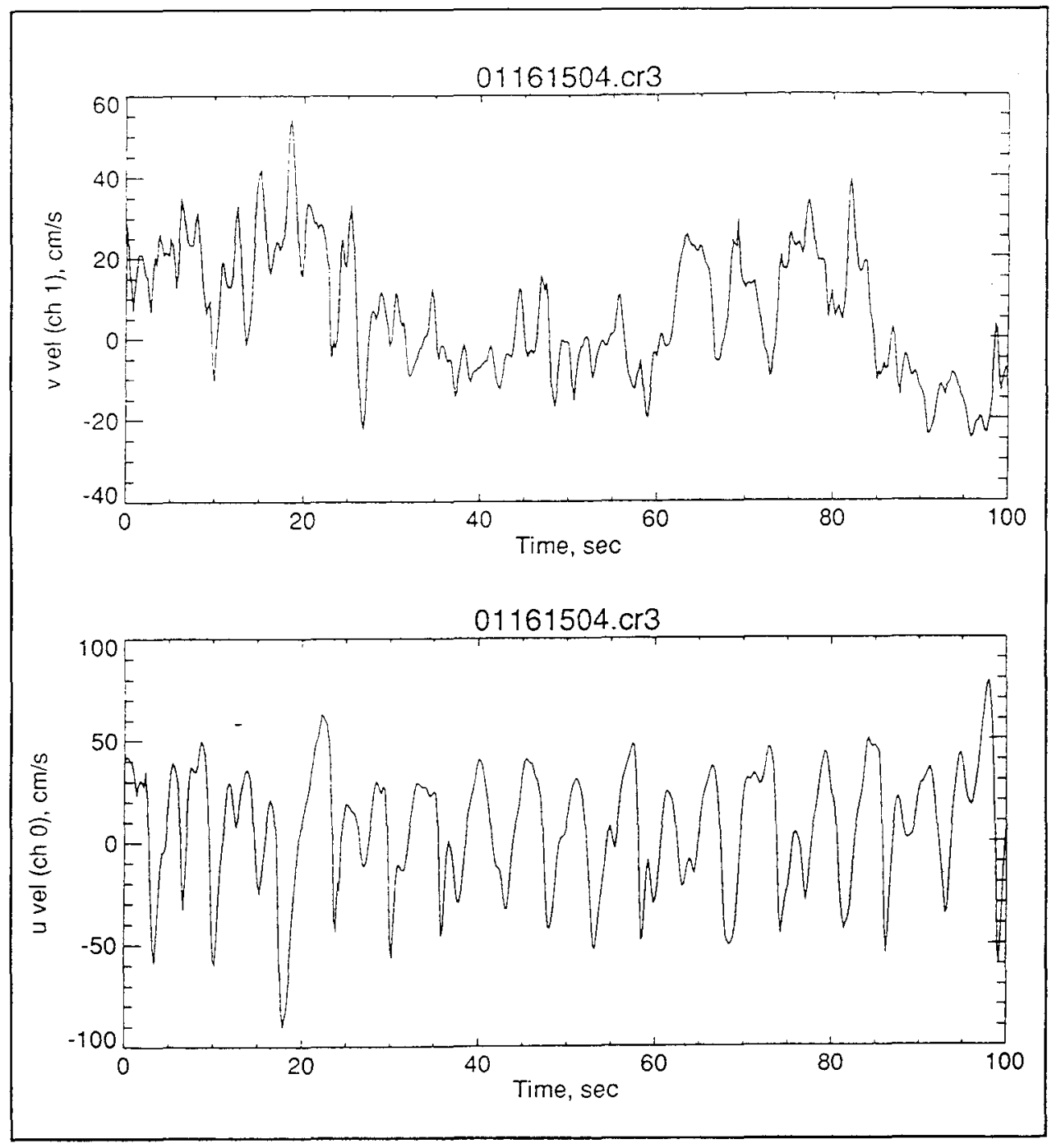

Figure 16. Example of platform ECM output on 16 January 1992 (from White 1992)

FOBS's were also deployed at the Colorado River as described in Chapter 3. Calibration and data handling were similar to that for the sled and platform data. Example FOBS output plots of the concentration and velocity are shown in Figure 18. The bottom panel in Figure 18 is ducted impeller cross-shore current meter data $(5 \mathrm{~cm}$ above bottom) in $\mathrm{cm} / \mathrm{s}$. Above it are sediment concentrations in grams per liter at elevations from 1 to $4.5 \mathrm{~cm}$ above the bed. The values of the vertically integrated long-shore transport rate are given in Appendix C, Table $\mathrm{C} 2$. This portion of the monitoring program is discussed further in Beach (1995). 


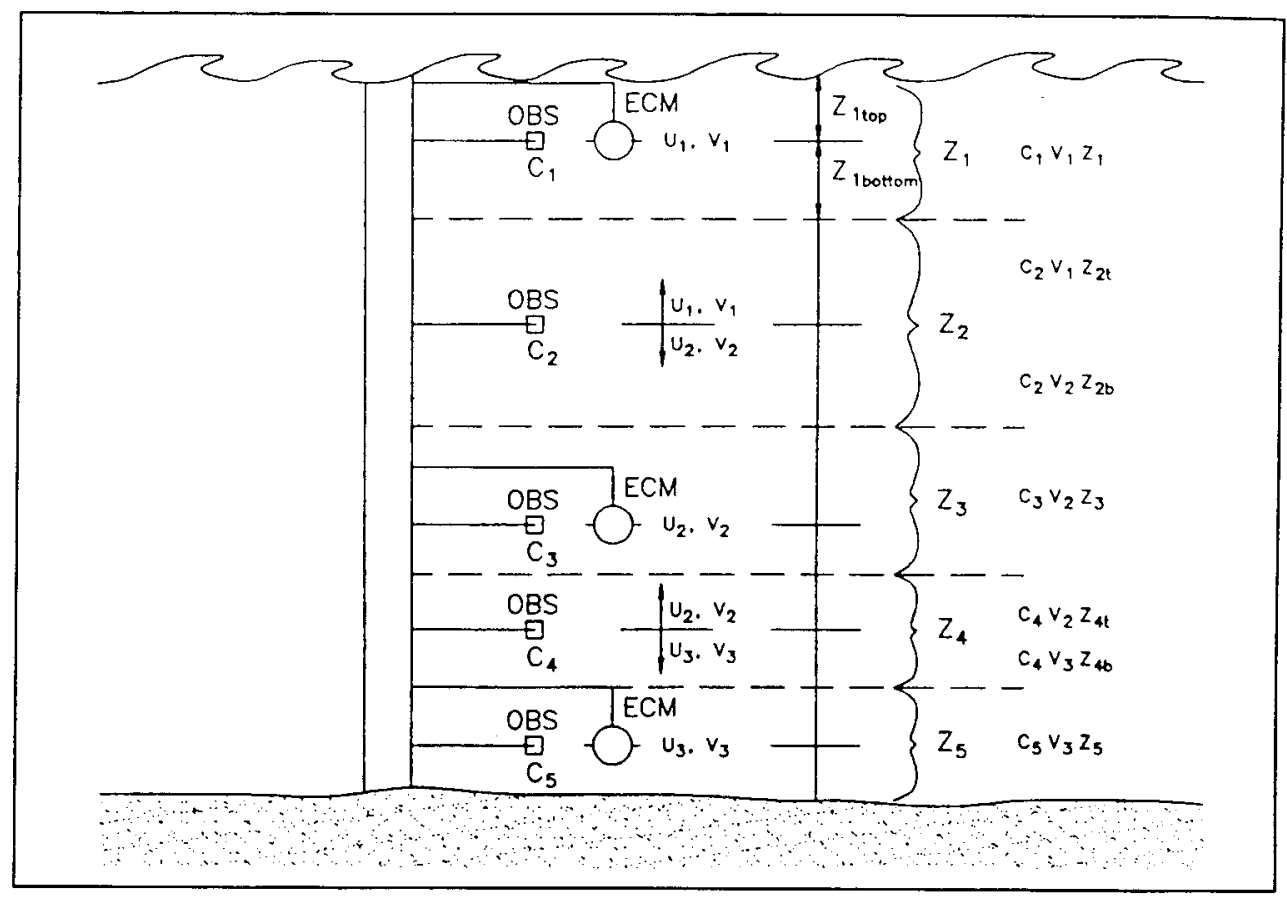

Figure 17. Regions of vertical integration of local sediment transport. Mid-points (dashed lines) between each type of gage (ECM and OBS) separate each region (from White 1994)

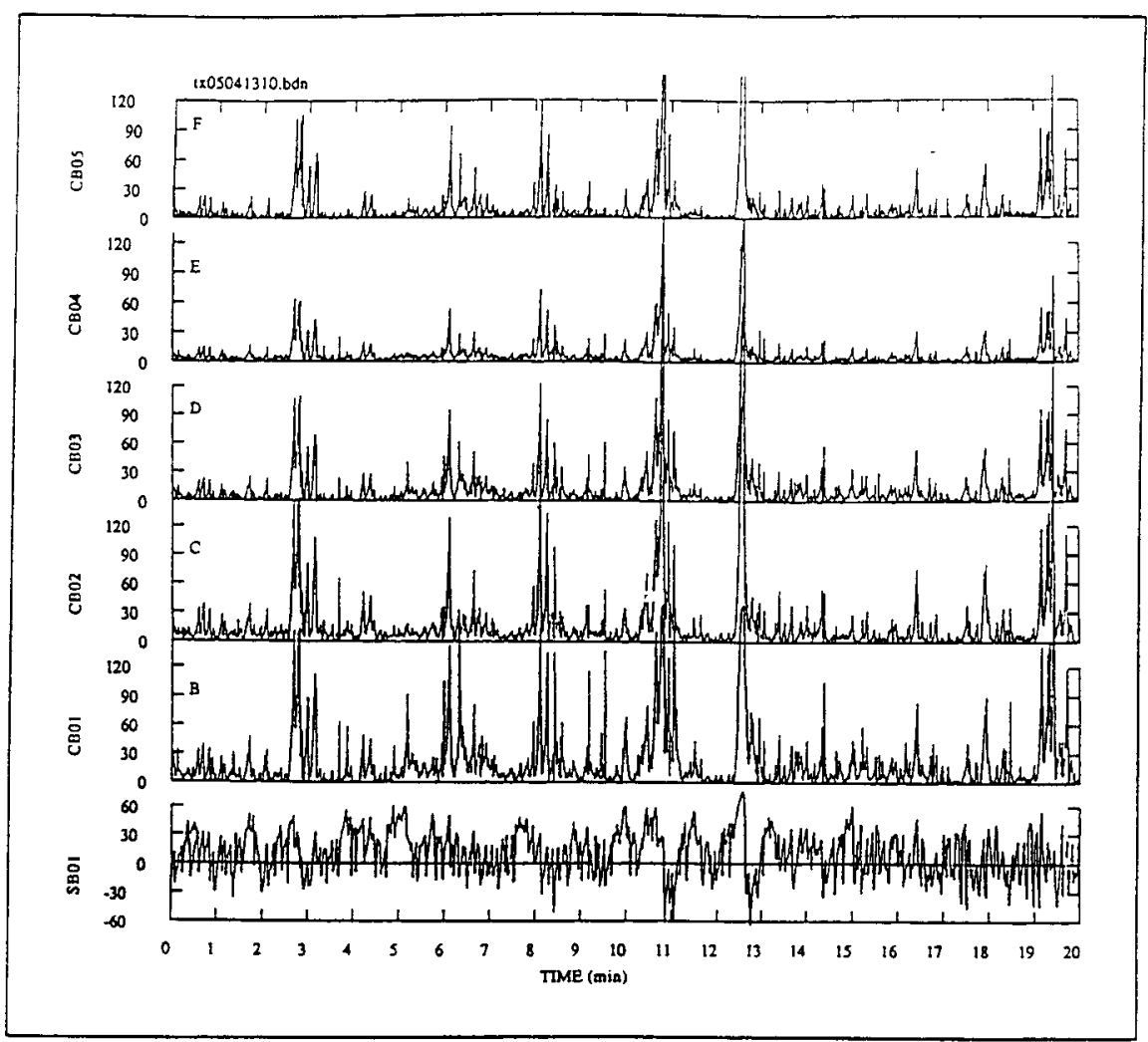

Figure 18. Example of FOBS tripod data on 4 May 1990 (from Beach 1995) 


\section{Shoreline and Nearshore Bathymetry Changes}

Beach profiles were taken northeast and southwest of the inlet in 1984 by SWG and in 1990, 1991, and 1992 by this monitoring effort on the range lines shown in Figure 9. Profile data are available in Liang (1995). Several problems with the surveys limited their usefulness in making quantitative assessments of beach change volumes. The 1984 data extended only $125 \mathrm{~m}$ offshore. Later data sets showed that the depth of closure was substantially seaward of this distance.

Because access to the southwestern side of the inlet was limited, no surveys were taken there in 1990, and later surveys were somewhat abbreviated. This beach was used as the deposition site for the material dredged from the impoundment basin in 1990 and 1992. Unfortunately, as a result of the dredged material deposition, several principal 1984 benchmarks southwest of the inlet were lost, resulting in a poor match in range locations and reference elevations between the 1984 survey and later surveys. The later surveys also either did not extend far offshore or did not cover all the range lines.

An analysis by Liang (1995) showed that the beach northeast of the inlet accreted between 1984 and 1990, and then lost some of that amount by 1992 . Between 1984 and 1990, the average accretion was $19.2 \mathrm{~m}$ or $3.2 \mathrm{~m} /$ year, while the 1984 to 1992 average accretion was $8.8 \mathrm{~m}$ or $1.1 \mathrm{~m} /$ year. Figure 19 shows the changes in shoreline position during this time interval. Out to a distance of $125 \mathrm{~m}$, the 3-km-long section northeast of the river mouth gained about 135,000 cubic meters between 1984 and 1990. From 1990 to 1992, the same section lost about 19,000 cubic meters out to the $125-\mathrm{m}$ line. However, using the entire set of 1990 and 1992 profiles (extending about $700 \mathrm{~m}$ offshore) the total volume loss in the $3-\mathrm{km}$-long beach section was about 85,000 cubic meters, roughly four times the loss to $125 \mathrm{~m}$.

Limited analysis could be made from the data collected southwest of the inlet because surveys were not well-timed to monitor the beach nourishment events. However, general trends were similar to that on the northeast beach. The shoreline prograded between the 1984 and 1992 surveys. This was probably principally due to the fact that large amounts of fill $\left(1.36 \times 10^{6}\right.$ cubic meters, see Table 8) were placed on this beach during that time. In the 6 months between the 1991 and 1992 surveys, the first $900-\mathrm{m}$ section southwest of the inlet lost a total volume of about 22,100 cubic meters indicating that this beach is still erosional in nature.

The Matagorda Peninsula shoreline in the vicinity of the mouth of the Colorado River was modeled by Heilman (1995) (see also Heilman and Edge 1996) using a GENESIS type numerical model. For an overview of the GENESIS modeling program, see Hanson and Kraus (1989). This numerical modeling effort used the wave and profile data collected as part of this 


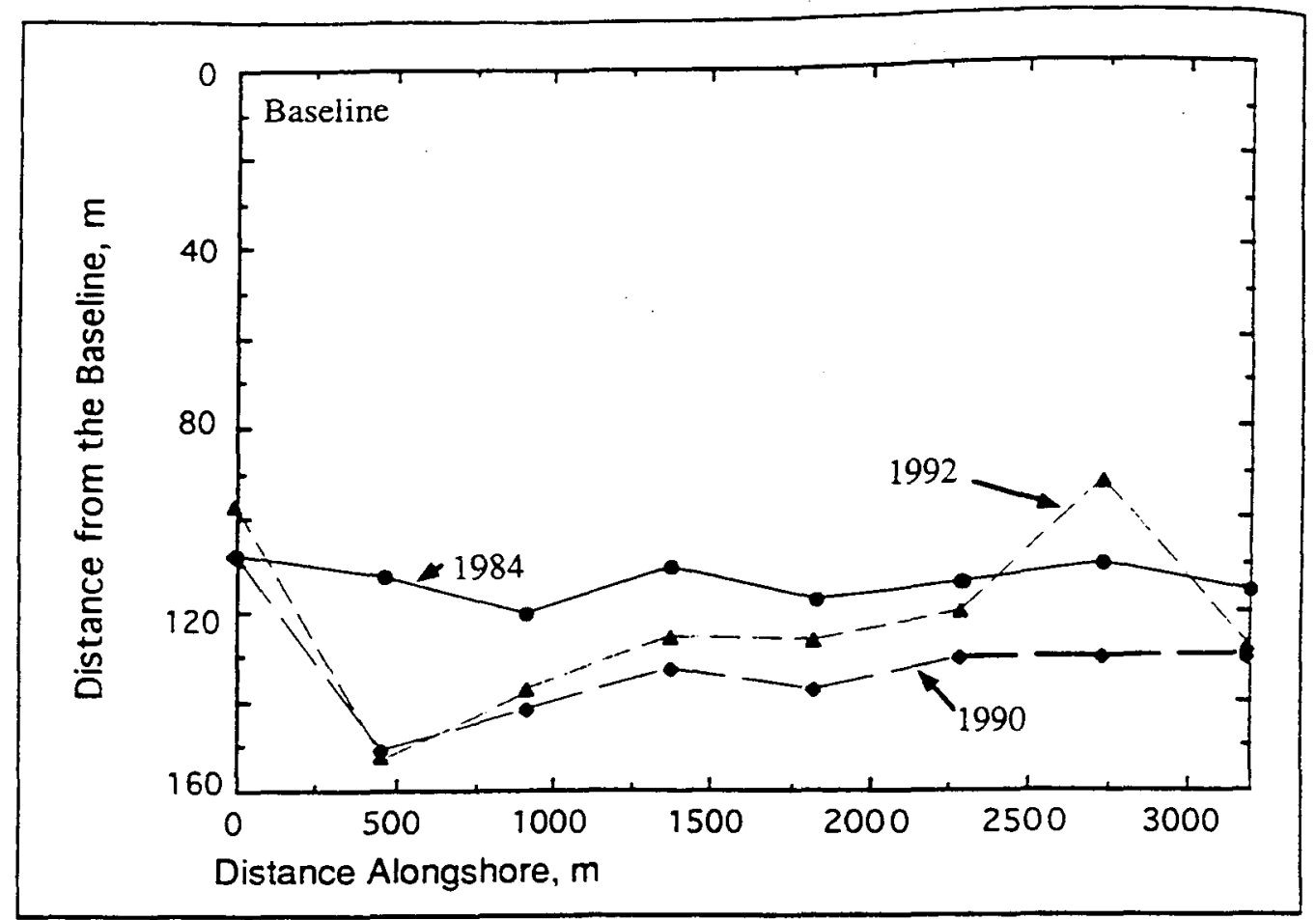

Figure 19. Shoreline positions northeast of the mouth of the Colorado River between 1984 and 1992. Longshore distances are from NJO. (from Liang 1995)

monitoring program. The results indicate a net sediment transport rate of 310,000 cubic meters to the southwest and a gross transport rate of 580,000 cubic meters. These results are discussed further in Chapter 5.

\section{Impoundment Basin Surveys}

In addition to the beach profiles, other bathymetry surveys were made across the impoundment basin and navigation channel by CERC and SWG personnel. Because of more complete coverage, the SWG surveys were used for analysis. Locations of the SWG impoundment basin survey range lines are shown in Figure 2, a plan view of the project site, and Table 7 provides survey data availability.

Initial SWG impoundment basin surveys were taken in March 1990, just after the basin had been dredged. Subsequent surveys analyzed in this report continued until September 1992, when new dredging operations in the impoundment basin began. Dredging volumes are shown in Table 8 .

The survey data were input into the Interactive Survey Reduction Program (ISRP) for processing (Birkemeier 1984). To calculate volume changes along 
each survey line, the ISRP-formatted data were used in the Beach Morphology Analysis Package (BMAP), a program developed by CERC to inspect and analyze two-dimensional beach profiles and beach profile changes (Sommerfeld et al. 1994). Although the impoundment basin profiles do not resemble typical beach profiles, BMAP was able to calculate volumetric change in successive surveys along the range lines. Example survey data are plotted in Figure 20. Figure 20 shows successive surveys along range line 33600 as the basin infilled. From bottom to top, the four surveys were taken in March 1990, August 1990, April 1991, and September 1992. Northeast is on the left-hand side of the plot, southwest on the right. The large flat depression and V-shaped depression are the impoundment basin and navigation channel, respectively. Volume changes along each range line are given in Table 9.

\section{Sediment Grain Size}

Sediment grab samples were taken on the beach, in the surf zone, and in the impoundment basin at the mouth of the Colorado River on October 18, 1989, and February 11, 1994. The samples were sieved using standard techniques to characterize the sediments in this area. The results are shown in Table 10. An example distribution curve is shown in Figure 21. These sediments are fine sands with median sizes in the range $0.17-0.22 \mathrm{~mm}$, and contained a small percentage of silts and clays.

The samples are much coarser than the material carried to the sea by the Colorado River. The results of a 1965 analysis of 113 sediment samples taken from the river in the vicinity of the GIWW show that 63 percent of the river-borne sediments are finer than $0.002 \mathrm{~mm}$. Thus, the majority of the material consists of clay-sized particles. Only about the coarsest 1 percent are fine sands or coarser (U.S. Army Engineer District, Galveston 1977). Additional sediment samples were taken by SWG on August 16,1994, in the river at and near the mouth and in the impoundment basin. All of these samples showed greater fractions of silt and clay than any of the monitoring effort samples discussed above. Five samples in the entrance channel at the mouth had median grain sizes of 0.10 to $0.18 \mathrm{~mm}$ and silt and clay fractions of 12 to 34 percent. River samples 427 and $731 \mathrm{~m}$ inland from the mouth showed a mixture of beach and river sediments. These samples had mean grain diameters of $0.04 \mathrm{~mm}$ and contained 60 - to 80 -percent silt and clay fractions. The one impoundment basin sample had a mean grain diameter of $0.04 \mathrm{~mm}$ and contained 88-percent silt and clay. This shows that riverine sediments were reaching the mouth even after the river was diverted into Matagorda Bay and is consistent with casual observations that the impoundment basin sediments contained a patchy mix of river- and beach-derived sediments. 


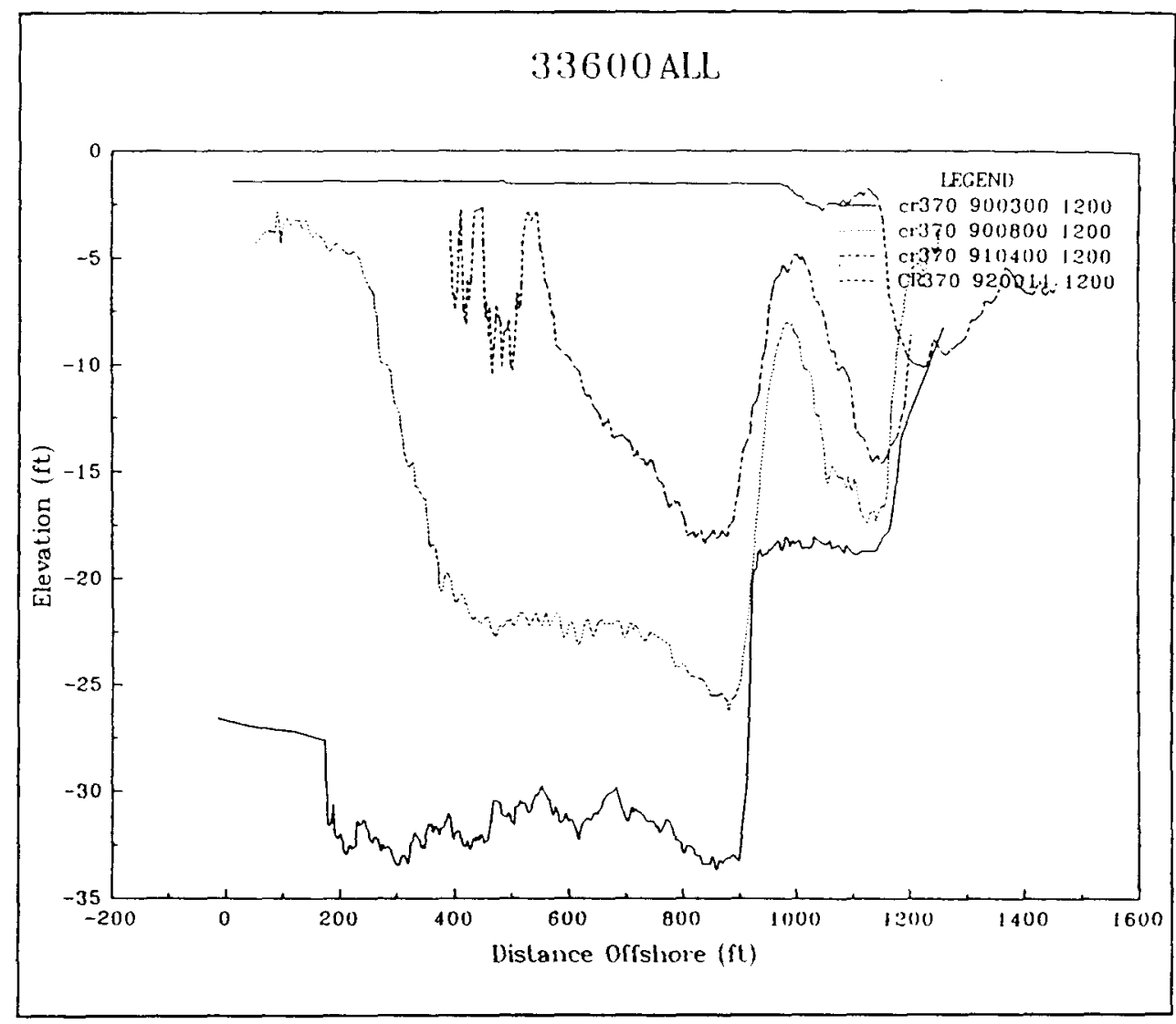

Figure 20. Example of impoundment basin surveys

\begin{tabular}{|c|c|c|c|c|c|c|c|c|}
\hline \multicolumn{9}{|c|}{$\begin{array}{l}\text { Table } 9 \\
\text { Calculated Impoundment Basin Material Volume }\end{array}$} \\
\hline \multirow[b]{2}{*}{$\begin{array}{l}\text { Survey } \\
\text { Line }\end{array}$} & \multirow[b]{2}{*}{$\begin{array}{l}\text { Start-End } \\
\mathrm{ft}\end{array}$} & \multirow[b]{2}{*}{ O EL } & \multicolumn{6}{|c|}{$\begin{array}{c}\text { Calculated Volumes per Survey } \\
\mathrm{yd}^{3} / \mathrm{ft}\end{array}$} \\
\hline & & & 9003 & 9005 & 9008 & 9104 & 9204 & 9209 \\
\hline 34200 & $185-1133$ & -30.0 & & 225 & 464 & 634 & & 1039 \\
\hline 34100 & $96-1204$ & -32.5 & & 292 & 499 & & 1152 & \\
\hline 34000 & $54-1168$ & -32.5 & & 285 & 443 & & 1212 & 1222 \\
\hline 33900 & $93-1154$ & -32.5 & $171^{\prime}$ & 236 & 420 & & 1155 & \\
\hline 33800 & $168-1183$ & -32.5 & 185 & & 402 & 730 & 1117 & 1125 \\
\hline 33700 & $96-1208$ & -32.5 & 128 & & 555 & & 1240 & \\
\hline 33600 & $51-1202$ & -33.0 & 196 & & 699 & 979 & & 1304 \\
\hline
\end{tabular}




\begin{tabular}{|c|c|c|c|c|c|c|}
\hline \multicolumn{7}{|c|}{$\begin{array}{l}\text { Table } 10 \\
\text { Surf Zone Sediment Grain-Size Distributions }\end{array}$} \\
\hline $\begin{array}{c}\text { Sample } \\
\text { Location }\end{array}$ & $\begin{array}{c}\text { Median } \\
\mathrm{mm}\end{array}$ & $\begin{array}{c}\text { Median } \\
\phi \\
\end{array}$ & Mean & Dev. & Skew & Kurt. \\
\hline Inner Surf Zone' & 0.17 & 2.58 & 2.58 & 0.36 & -0.45 & 5.52 \\
\hline Storm Flat Beach & 0.18 & 2.47 & 2.50 & 0.31 & 0.08 & 4.28 \\
\hline Berm & 0.22 & 2.18 & 2.03 & 0.72 & -1.96 & 9.94 \\
\hline Dunes & 0.17 & 2.59 & 2.6 & 0.28 & -0.39 & 14.26 \\
\hline Inner Surf Zone & 0.17 & 2.55 & 2.45 & 0.69 & -4.02 & 23.98 \\
\hline Outer Surf Zone & 0.17 & 2.56 & 2.31 & 0.99 & -2.43 & 9.04 \\
\hline $\begin{array}{l}\text { Impoundment } \\
\text { Basin }\end{array}$ & 0.18 & 2.51 & 2.53 & 0.29 & -1.08 & 24.36 \\
\hline
\end{tabular}

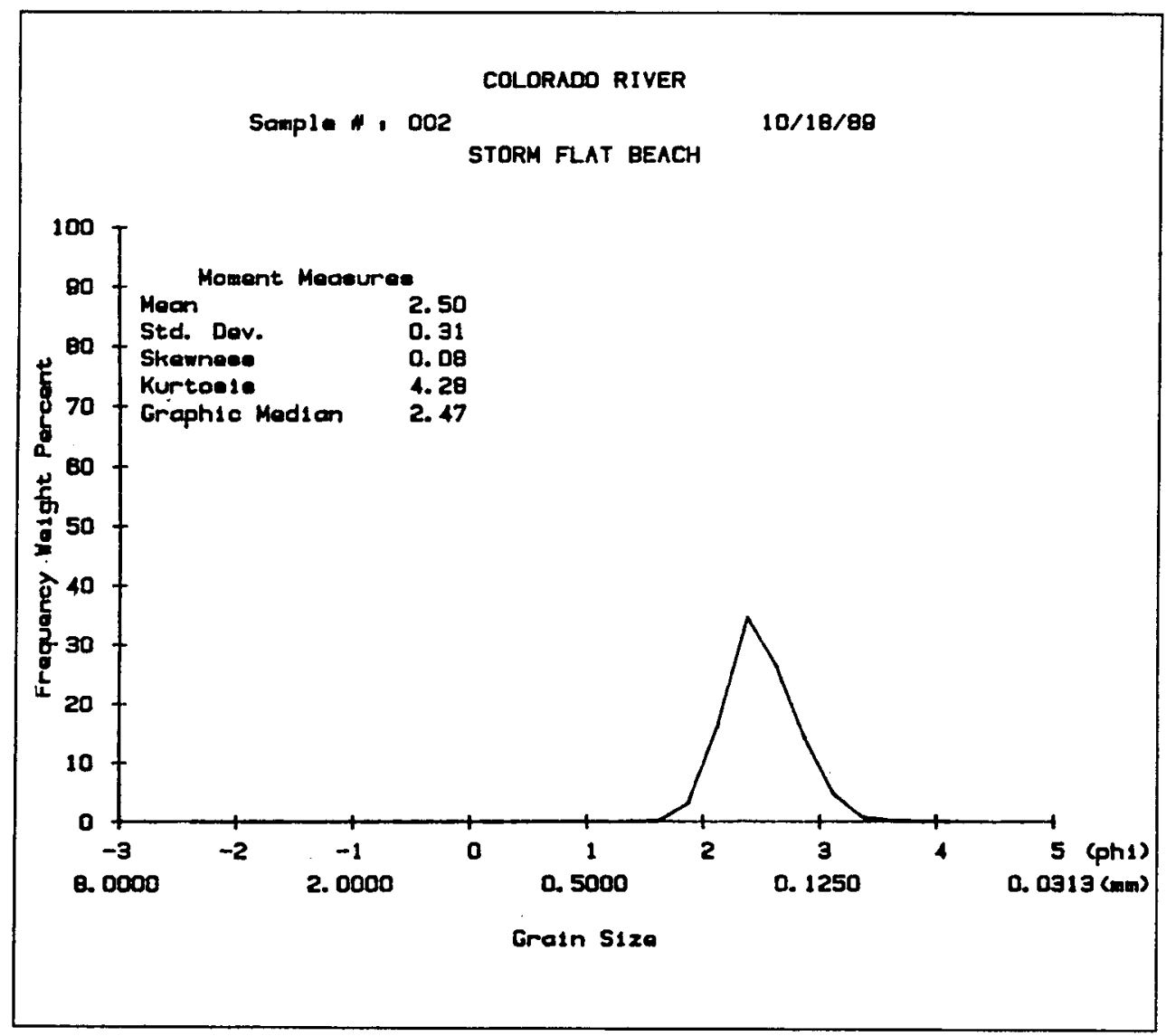

Figure 21. Representative grain size distribution curve for the beach 


\section{Tides and Currents}

Tide gages deployed at the mouth of the river in May 1990 were not relocated during a scheduled retrieval in December 1990, and are presumed to have been buried by sediment. Additional gages were not deployed at that location, because tidal fluctuation information was available from the offshore wave gages. These data showed that the Colorado River area has a mainly diurnal tide with a spring range of approximately $0.9 \mathrm{~m}$. During neap tides a semidiurnal component becomes evident. This is in agreement with other published values (e.g. Aronow and Kaczorowski 1985). Tidal data are shown in Figure 22.

Currents were measured at the mouth of the river during the first surf zone experiment using an upward-looking, narrow-band ADCP. A Puv gage was deployed adjacent to the ADCP to measure currents in the bottom meter of the water column. The data were combined and processed by Scientific Services as described in Lacey (1990).

For times of low rainfall within the Colorado River watershed, currents in the Colorado River mouth are mainly tidal driven. An example is shown in Figure 23 for the period May 4-7, 1990. This sample corresponds to a period of neap tide range. The maximum ebb and flood currents of 2.5 to $3 \mathrm{~m} / \mathrm{sec}$ shown in Figure 23 are substantially greater than at most tidal inlets. Spring tides produce substantially greater tidal amplitudes, but because spring tides are diurnal, the currents are not correspondingly stronger. A comparison of these data with published current data predictions for Galveston bay entrance (U.S. Department of Commerce 1990) indicates that astronomically driven tidal currents at the mouth of the Colorado River may occasionally reach up to $6 \mathrm{~m} / \mathrm{sec}$. However, periods of high rainfall could greatly strengthen ebb flows and decrease flood currents.

The ADCP was also used to make a qualitative assessment of the suspended sediment load in the river by plotting the backscatter intensity. An example of this is shown in Figure 24. However, no attempt was made to extract quantitative suspended transport rates from these data.

Mean coastal current information in water depths of about $10 \mathrm{~m}$ was also obtained from the offshore Puv (but not DWG) wave gages. These mean currents, shown in a current rose, Figure 25, are 300-sec averages of data obtained hourly. Figure 25 shows the direction that the currents were coming from. These coastal currents were generally parallel to shore, with a plurality being from the southwest. Speeds were generally less than $0.5 \mathrm{~m} / \mathrm{sec}$. 


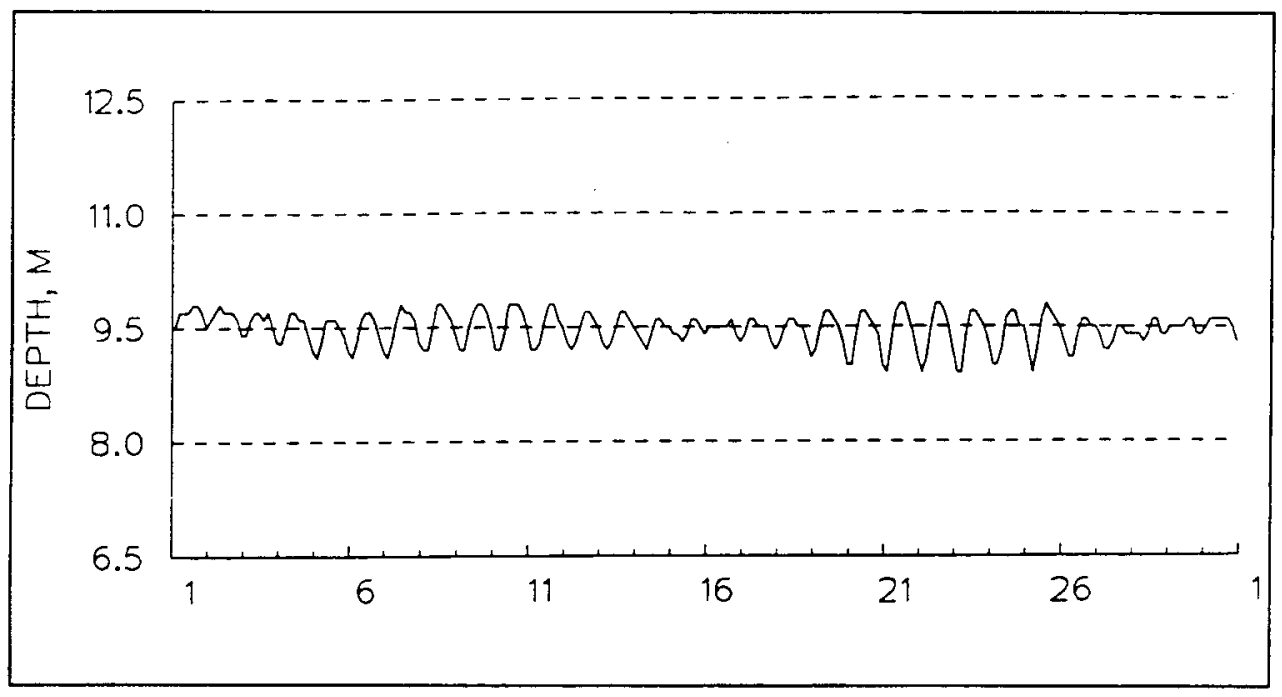

Figure 22. Tide curve taken on June 1990 from wave gage successive mean water levels

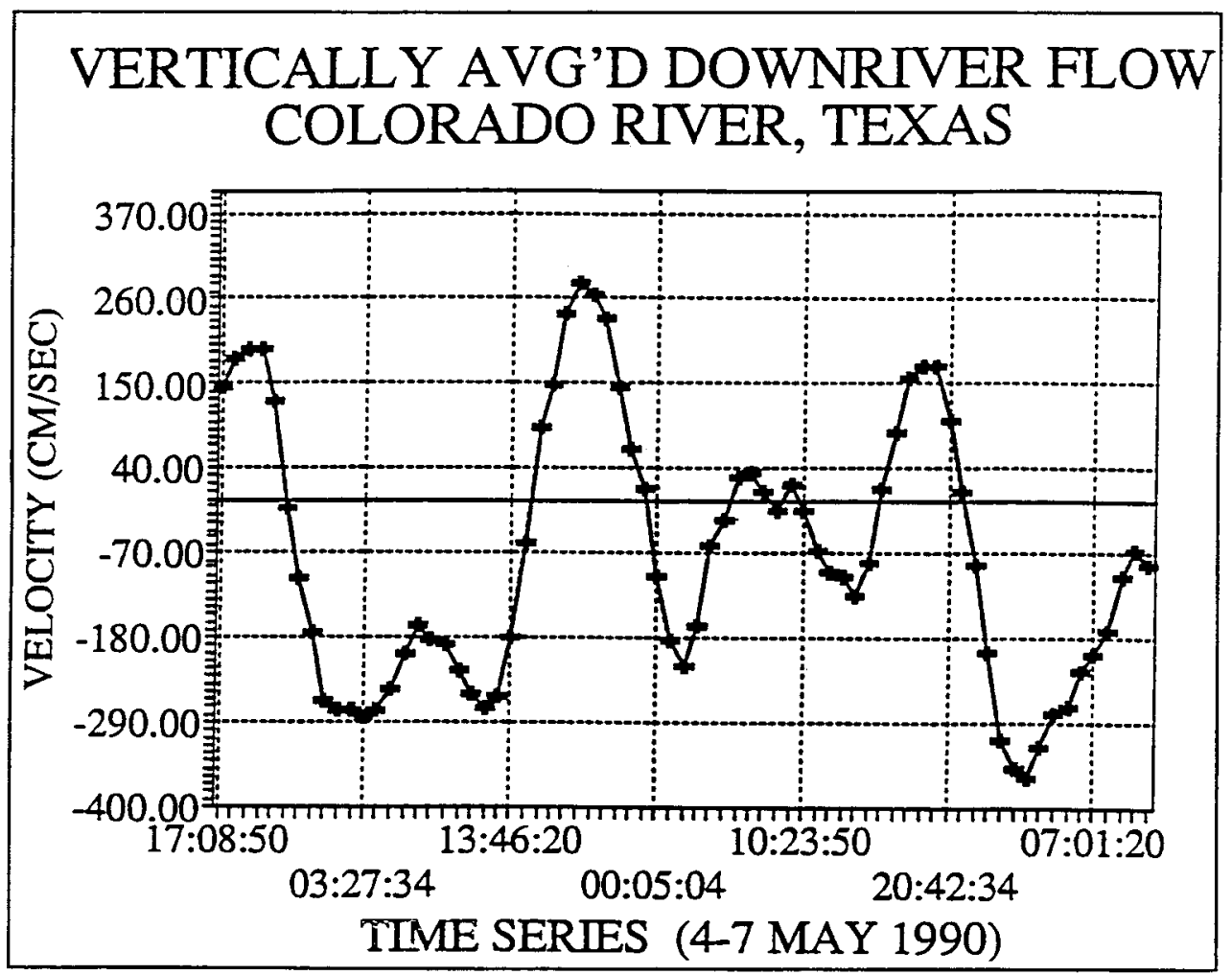

Figure 23. Example of ADCP-measured current flow at the mouth of the Colorado River, TX. Downriver (ebb) flow is positive (from Lacey1990) 


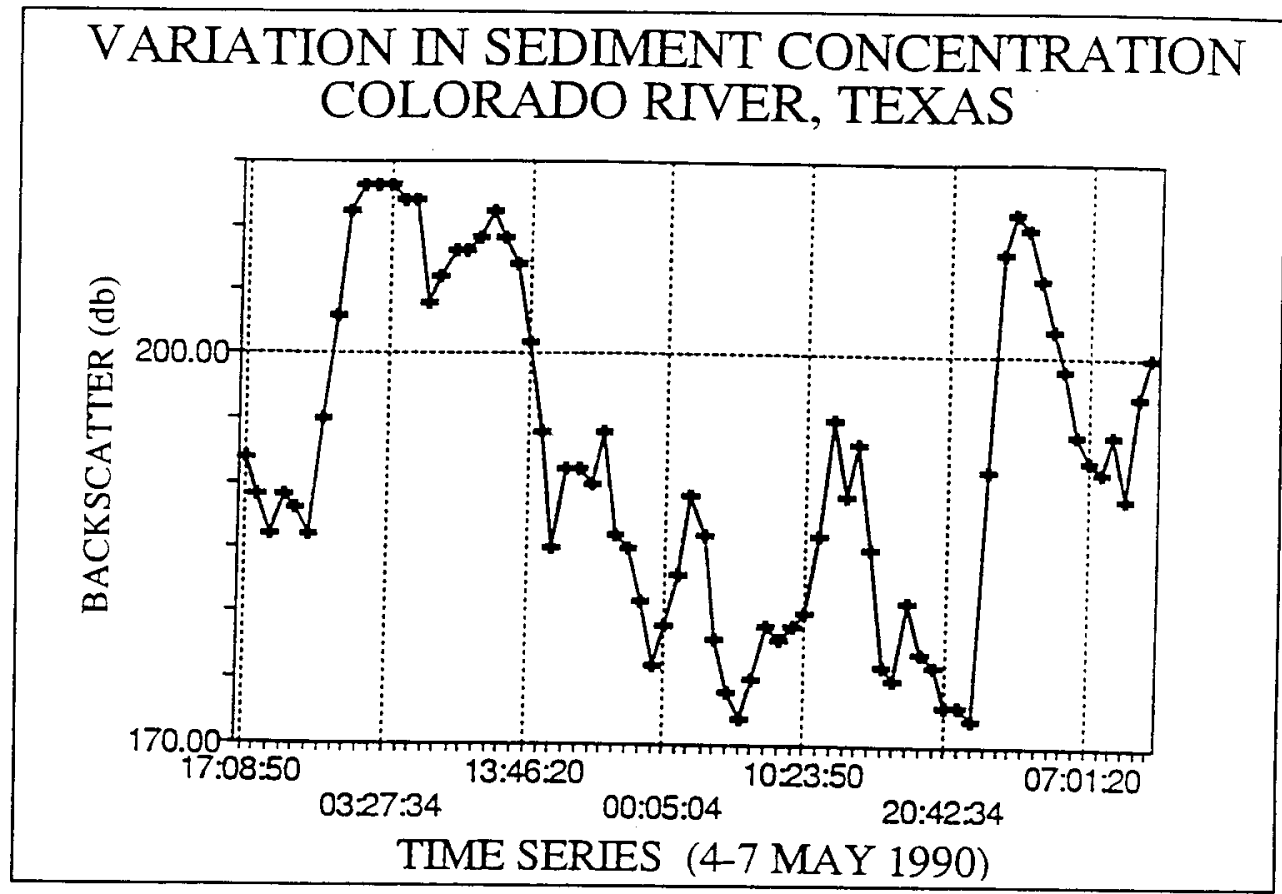

Figure 24. Example of relative suspended sediment load at the mouth of the Colorado River, TX. Vertical scale represents the vertically averaged backscatter intensity, a qualitative measure of the suspended load (Lacey 1990)

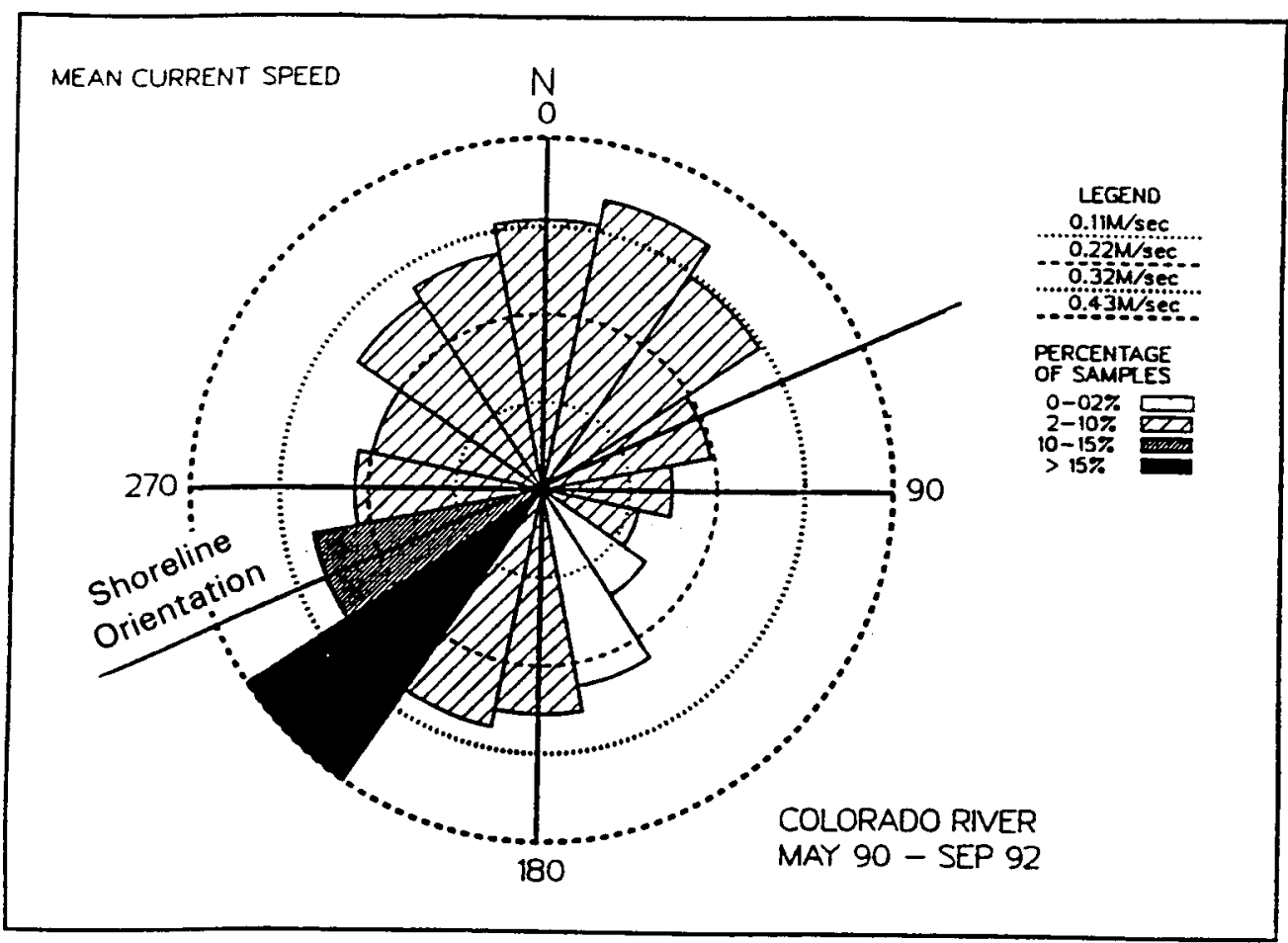

Figure 25. Offshore current rose for Colorado River, TX, May 1990 to September 1992. Note: shoreline runs on a $65-$ to 245 -degree bearing; $1 \mathrm{~m} / \mathrm{sec}=1.94$ knots 


\section{Prediction of Sediment Transport Rates}

\section{Calculations of Longshore Transport Rate}

Previously, numerous calculations have been made of the longshore transport rate along the Texas coast. These calculations have varied in their methods and reliability, and unfortunately, they have also varied considerably in their results. Table 11 lists a representative sample of published estimates made between Galveston and Corpus Christi. It is not meant to be inclusive, but rather to show that the range of transport rate predictions in this area is rather large. In the "Method" column in Table 11, Littoral Environmental Observations (LEO) refers to data collected by standardized visual surf zone observations. For further information on this procedure and the data see Schneider (1981) or Thomas (1994). "SPM" refers to obtaining longshore transport rates from wave data using some form of the SPM (1984) formula discussed below. Gages refers to data collected by this monitoring program, and "GENESIS" refers to the numerical model discussed in Chapter 4.

\section{Methods}

One of the main thrusts of this research project was to determine the average yearly sediment transport rate along this section of coastline. Attempts were made to estimate this value by three methods. The first method was to apply the standard SPM formula to the wave data. The second was to make short-term measurements of the transport at points within the surf zone and compare these rates with the measured offshore waves to produce an improved transport model calibrated for this site. Then, this new model could be applied to the entire wave record to obtain a yearly average transport rate. The third method was to measure the infilling rate of the impoundment basin to obtain an average yearly transport rate. Each of these methods is discussed in detail below. 


\begin{tabular}{|c|c|c|c|c|c|c|}
\hline \multicolumn{7}{|c|}{$\begin{array}{l}\text { Table } 11 \\
\text { Selected Texas Longshore Sediment Transport Estimates }\end{array}$} \\
\hline Author & $\begin{array}{c}\text { Net } \\
\mathrm{m}^{3} / \mathrm{yr} \\
\text { and } \\
\text { direction }\end{array}$ & $\begin{array}{l}\text { Gross } \\
\mathrm{m}^{3} / \mathrm{yr}\end{array}$ & Location & $\begin{array}{l}\text { Dist. } \\
\text { from } \\
\text { C. R. }\end{array}$ & $\begin{array}{l}\text { Data } \\
\text { Years }\end{array}$ & Method \\
\hline $\begin{array}{c}\text { Mason } \\
1981\end{array}$ & $\begin{array}{c}304,000 \\
\text { to } s w\end{array}$ & - & Galveston & $\begin{array}{l}130 \\
\mathrm{~km} \\
\mathrm{nw}\end{array}$ & 1975 & $\begin{array}{l}\text { LEO, } \\
\text { SPM }\end{array}$ \\
\hline $\begin{array}{l}\text { Mason } \\
1981\end{array}$ & $\begin{array}{l}178,000 \\
\text { to sw }\end{array}$ & - & $\begin{array}{l}\text { San Luis } \\
\text { Pass }\end{array}$ & $\begin{array}{l}100 \\
\mathrm{~km} \\
\mathrm{nw}\end{array}$ & 1975 & $\begin{array}{l}\text { LEO, } \\
\text { SPM }\end{array}$ \\
\hline $\begin{array}{l}\text { Mason } \\
1981\end{array}$ & $\begin{array}{l}67,000 \\
\text { to sw }\end{array}$ & . & Freeport & $\begin{array}{l}80 \mathrm{~km} \\
\mathrm{nW}\end{array}$ & 1975 & $\begin{array}{l}\text { LEO, } \\
\text { SPM }\end{array}$ \\
\hline $\begin{array}{c}\text { Mason \& } \\
\text { Sorenson } \\
1971\end{array}$ & $\begin{array}{c}15,000 \text { to } \\
69,000 \\
\text { to sw }\end{array}$ & $\begin{array}{c}229,000 \\
\text { to } \\
765,000\end{array}$ & $\begin{array}{l}\text { Brown } \\
\text { Cedar Cut }\end{array}$ & $\begin{array}{c}30 \mathrm{~km} \\
\mathrm{nw}\end{array}$ & & Various \\
\hline $\begin{array}{c}\text { USAED } \\
\text { Galveston } \\
1977\end{array}$ & - & 172,000 & $\begin{array}{l}\text { Colorado } \\
\text { River }\end{array}$ & 0 & $\begin{array}{c}1953- \\
1954\end{array}$ & $\begin{array}{c}\text { Bathymetry } \\
\text { changes }\end{array}$ \\
\hline $\begin{array}{l}\text { Heilman } \\
1995\end{array}$ & $\begin{array}{c}152,000 \\
\text { to sw }\end{array}$ & - & $\begin{array}{l}\text { Colorado } \\
\text { River }\end{array}$ & 0 & $\begin{array}{c}1935- \\
1982\end{array}$ & $\begin{array}{c}\text { Bathymetry } \\
\text { changes }\end{array}$ \\
\hline $\begin{array}{c}\text { Heilman } \\
1995\end{array}$ & $\begin{array}{c}214,000 \\
\text { to sw }\end{array}$ & - & $\begin{array}{l}\text { Colorado } \\
\text { River }\end{array}$ & 0 & $\begin{array}{c}1984- \\
1992\end{array}$ & $\begin{array}{c}\text { Bathymetry } \\
\text { changes }\end{array}$ \\
\hline $\begin{array}{c}\text { Heilman } \\
1995\end{array}$ & $\begin{array}{c}310,000 \\
\text { to sw }\end{array}$ & 580,000 & $\begin{array}{l}\text { Colorado } \\
\text { River }\end{array}$ & 0 & $\begin{array}{c}1990- \\
1992\end{array}$ & $\begin{array}{l}\text { Gauges, } \\
\text { GENESIS }\end{array}$ \\
\hline $\begin{array}{c}\text { USAED } \\
\text { Galveston } \\
1977\end{array}$ & - & $153,000+$ & $\begin{array}{l}\text { Matagorda } \\
\text { Ship } \\
\text { Channel }\end{array}$ & $\begin{array}{c}40 \mathrm{~km} \\
\mathrm{sw}\end{array}$ & $\begin{array}{c}1964- \\
1971\end{array}$ & $\begin{array}{c}\text { Bathymetry } \\
\text { changes }\end{array}$ \\
\hline $\begin{array}{c}\text { Watson \& } \\
\text { Behrens } \\
1976\end{array}$ & $\begin{array}{c}67,000 \\
\text { to sw }\end{array}$ & 555,000 & $\begin{array}{l}\text { Corpus } \\
\text { Christi }\end{array}$ & $\begin{array}{c}160 \\
\mathrm{~km} \text { sw }\end{array}$ & $\begin{array}{c}1972- \\
1975\end{array}$ & $\begin{array}{l}\text { LEO, } \\
\text { SPM }\end{array}$ \\
\hline
\end{tabular}

\section{SPM Method Calculations}

The wave data were used to calculate the longshore sediment transport rate using the radiation-stress equation given in the SPM (1984) Equation 4-49 as:

$$
Q=\frac{K P_{\ell s}}{\left(\rho_{s}-\rho\right) g a^{\prime}}
$$


where:

$Q=$ sediment volume transport

$K=$ empirical coefficient

$P_{\ell s}=$ longshore energy flux

$\rho_{\mathrm{s}}=$ density of sand

$a^{\prime}=$ volume concentration $(0.6)$

Also see Galvin (1979) and Galvin and Schweppe (1980).

Since the wave measurements were in deep water or nearly so, small-amplitude wave theory approximations were used to obtain the breaker line $\mathrm{P}_{\mathrm{ts}}$ value from deepwater values using SPM (1984) Equation 4-45:

$$
P_{\ell s}=0.05 \rho g^{3 / 2} H_{0}^{S / 2}\left(\cos \alpha_{0}\right)^{1 / 4} \sin 2 \alpha_{0}
$$

where $H_{0}$ is the deepwater significant wave height and $\alpha_{0}$ is the deepwater wave angle. A deepwater depth $\left(d_{0}\right)$ was calculated from the peak period $\left(T_{\mathrm{p}}\right)$ as:

$$
d_{0}=0.78 T_{p}^{2}
$$

If this depth was greater than the gage depth, the wave height and angle were back-shoaled to obtain deepwater values for Equation 3.

Then the transport rate for each wave record was calculated from Equation 2 as:

$$
Q=0.13 P_{\text {es }}
$$

in cubic meters per hour for the DWG records or as:

$$
Q=0.40 P_{l s}
$$

in cubic meters per 3-hour period for the Puv wave records. Equations 5a and $5 \mathrm{~b}$ use a value of $\mathrm{K}=0.35$, since the significant wave height is being used. No attempt was made to alter this coefficient to adjust the results.

These values were then summed to produce transport rates per month. Since the wave data record had some gaps and also multiple years of data for some months, this monthly rate was multiplied by the number of possible data points in a month and divided by the number of actual data points that month. This produced the comparable monthly values shown in Figure 26. These rates were then summed to produce the yearly averages shown in Table 12 for the vicinity of Colorado River, TX. This method meant that months with fewer data points were more heavily weighted than months with more data. It was felt that this gave a more representative value of longshore transport than an equal weighting scheme, given the seasonal variation in wave climate shown in Figures 11 and 12. The values are fairly similar to that of Heilman (1995) (see Table 11, line 8 ) because the same data set and a similar procedure were used. 


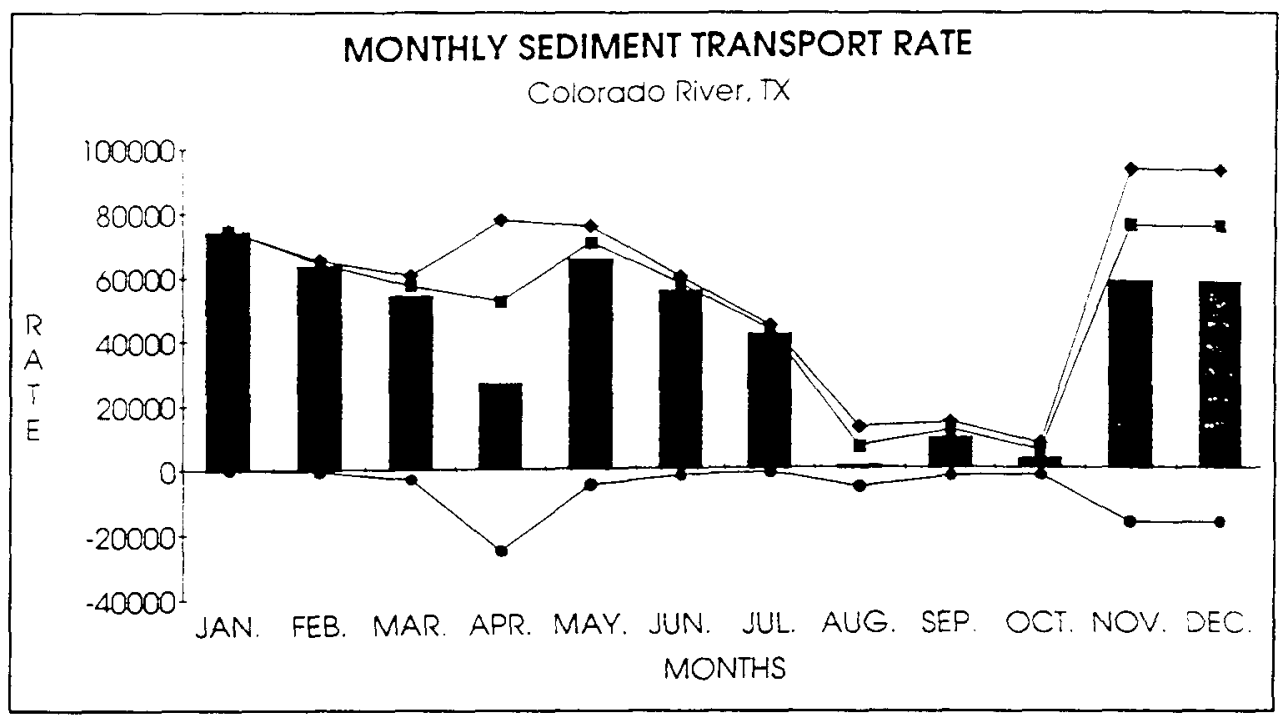

Figure 26. Monthly sediment transport rate, in cubic meters per month. Squares are the gross transport to the southwest, circles are the gross transport to the northeast, diamonds are total gross transport, and bars are the net transport. Calculated by SPM method

\begin{tabular}{||l|c||}
\hline $\begin{array}{l}\text { Table } 12 \\
\text { Average Sediment Transport Rates Calculated by SPM Method }\end{array}$ \\
\hline Direction & $\begin{array}{c}\text { Cubic meters } \\
\text { per year }\end{array}$ \\
\hline Gross rate to the southwest & 590,000 \\
\hline Gross rate to the northeast & 80,000 \\
\hline Net rate to the southwest & 510,000 \\
\hline Total gross transport & 670,000 \\
\hline
\end{tabular}

\section{Surf Zone Measurements}

As described in Chapter 4, the data from the stacked OBS and ECM's were vertically integrated to give sediment transport rates at sled locations in the surf zone. These local transport rates, listed in Appendix C, were then integrated across the surf zone to obtain total longshore sediment transport rates using visual estimates of the surf zone width taken from the field notes.

The procedure, as discussed in more detail in White (1994), was to compare these measured transport rates with the transport values predicted from the 
10-m wave gage using the SPM formula during the short-term experiments when both measurements could be obtained. This would allow the SPM formula to be calibrated with measured values. Then the calibrated formula could be applied to the entire wave data set to obtain a refined estimate of the annual longshore transport rate.

The SPM (1984) lists several similar formulas to calculate $P_{t s}$, the longshore energy flux, depending upon the wave data available. To test these formulas, the wave data were shoaled over the relatively simple nearshore topography off the mouth of the Colorado River to the breaker point using Snell's Law and linear shoaling (i.e., assuming that all the spectral energy occurs at the peak frequency). New direction angles were calculated at $3-\mathrm{m}$ intervals from the wave gage to the breakpoint. In addition to the use of Equation 3 discussed above, having both deepwater and breaker values for wave height, length, and direction allowed computation of the longshore energy flux in four additional ways corresponding to SPM (1984) Equations 4-40 (the most exact of the various equations), 4-44, 4-46, and 4-47. These four equations are:

$$
\begin{gathered}
S P M(4-40) \quad P_{\ell s}=\frac{\rho g}{16} H_{b}^{2} C_{g b} \sin 2 \alpha_{b} \\
S P M(4-44) \quad P_{\ell s}=0.0884 \rho g^{3 / 2} H_{b}^{5 / 2} \sin 2 \alpha_{b} \\
S P M(4-46) \quad P_{\ell s}=0.00996 \rho g^{2} T_{p} H_{0}^{2} \sin \alpha_{b} \cos \alpha_{0} \\
S P M(4-47) \quad P_{\ell s}=1.572 \rho g \frac{H_{b}^{3}}{T_{p}} \sin \alpha_{0}
\end{gathered}
$$

where the subscript $O$ means deep water and the subscript $b$ means the breaker line. $C_{g b}$ is the wave group speed at the breaker line, a function of the wave period and water depth. Then values of $Q$ were calculated using Equation 5a or $5 \mathrm{~b}$.

Then the OBS-derived transport rates were compared to the various wave gage-derived transport rates using simple linear regression of the form:

$$
y=m x+b
$$

where $y$ is the OBS data set and $x$ is the SPM data set. The slope of the regression is $m$, and $b$ is the offset. Correlation coefficients were also calculated. These values could be used to produce a transport formula of the form $Q_{\text {new }}=m^{*} Q_{o k i}+b$. The results are shown in Tables 13 and 14 . 


\begin{tabular}{|c|c|c|c|c|c|}
\hline \multicolumn{6}{|c|}{$\begin{array}{l}\text { Table } 13 \\
\text { Regression and Correlation of OBS and SPM Transport Data for } \\
\text { July 1991, from White (1994) }\end{array}$} \\
\hline $\begin{array}{c}\text { Data } \\
\text { Source }\end{array}$ & $\begin{array}{l}\text { Mean } \\
\text { Value } \\
(\mathrm{N} / \text { sec })^{9}\end{array}$ & $\begin{array}{l}\text { Standard } \\
\text { Deviation }\end{array}$ & $\begin{array}{l}m \\
\text { Slope of } \\
\text { Regression }\end{array}$ & $\begin{array}{l}b \\
\text { Intercept } \\
\text { (N/sec) }\end{array}$ & $\begin{array}{l}r \\
\text { Correlation } \\
\text { Coefficient }\end{array}$ \\
\hline $\begin{array}{l}\text { OBS } \\
\text { Calculations }\end{array}$ & 21.2 & 136. & & & \\
\hline $\begin{array}{l}\text { SPM } \\
\text { Eq. }(4-40)\end{array}$ & 156. & 815. & -0.00647 & 22.2 & -0.0388 \\
\hline $\begin{array}{l}\text { SPM } \\
\text { Eq. (4-44) }\end{array}$ & -4590 & 27600 . & 0.000181 & 22.0 & 0.0367 \\
\hline $\begin{array}{l}\text { SPM } \\
\text { Eq. }(4-45)\end{array}$ & 638. & 3270. & -0.001959 & 22.4 & -0.0470 \\
\hline $\begin{array}{l}\text { SPM } \\
\text { Eq. }(4-46)\end{array}$ & 721. & 3740. & -0.00136 & 22.1 & -0.0372 \\
\hline $\begin{array}{l}\text { SPM } \\
\text { Eq. (4-47) }\end{array}$ & 10300 & 52700 & -0.000113 & 22.3 & -0.0437 \\
\hline
\end{tabular}

\begin{tabular}{|c|c|c|c|c|c|}
\hline \multicolumn{6}{|c|}{$\begin{array}{l}\text { Table } 14 \\
\text { Regression and Correlation of OBS and SPM Transport Data for } \\
\text { January 1992, from White (1994) }\end{array}$} \\
\hline $\begin{array}{c}\text { Data } \\
\text { Source }\end{array}$ & $\begin{array}{l}\text { Mean } \\
\text { Value } \\
\left(\mathbf{N} / \text { sec }^{1}\right.\end{array}$ & $\begin{array}{l}\text { Standard } \\
\text { Deviation }\end{array}$ & $\begin{array}{c}m \\
\text { Slope of } \\
\text { Regression }\end{array}$ & $\begin{array}{c}b \\
\text { Intercept } \\
\text { (N/sec) }\end{array}$ & $\begin{array}{l}r \\
\text { Correlation } \\
\text { Coefficient }\end{array}$ \\
\hline $\begin{array}{l}\text { OBS } \\
\text { Calculations }\end{array}$ & -1200. & 2620. & & & \\
\hline $\begin{array}{l}\text { SPM } \\
\text { Eq. (4-40) }\end{array}$ & 131. & 291. & -8.44 & -95.9 & -0.936 \\
\hline $\begin{array}{l}\text { SPM } \\
\text { Eq. }(4-44)\end{array}$ & 936. & 3190. & -0.805 & -452 & -0.980 \\
\hline $\begin{array}{l}S P M \\
\text { Eq. (4-45) }\end{array}$ & 91.0 & 264. & 0.169 & -1220 & 0.0170 \\
\hline $\begin{array}{l}\text { SPM } \\
\text { Eq. (4-46) }\end{array}$ & 597. & 1310. & -1.86 & -93.5 & -0.932 \\
\hline $\begin{array}{l}\text { SPM } \\
\text { Eq. (4-47) }\end{array}$ & -745 & 3690. & 0.667 & -706 & 0.933 \\
\hline
\end{tabular}


Unfortunately, correlations between the two methods were not consistently high. All correlation values for the July 1991 experiment were quite low $(<0.002)$. Some correlation values for the January 1992 experiment were high (near 1.0), but many of these predicted transport in the wrong direction (thus, they had high anti-correlations). White (1994) discusses these problems in more detail and suggests several possible explanations. White (1994) also notes a disturbing lack of agreement between the various SPM (1984) formula (Equations 6-9) predictions. These issues are the subject of ongoing research. However, because of the disagreement in these results, the OBS data were not used further to determine the average yearly longshore transport rate at the Colorado River.

Research was conducted to investigate one possible reason for the poor correlations between the two procedures. Sled 1 was usually positioned just outside the breaker line. This sled contained a pressure sensor and three current meters. Though not designed for this purpose, the gages were combined to form a directional wave gage (a Puv gage). Adjustments were made in the data processing because the sensors were not co-located and thus contained small phase shifts in their signals, and realistic directional spectra were obtained for the January 1992 data. These data were then considered to be measured wave values at the breaker line. Equation 6 was used to obtain an additional set of transport rate values. These data were compared with the OBS transport data and with the shoaled 10-m-deep wave gage data using the linear regression method discussed above. The results are shown in Table 15.

\section{Table 15 \\ Regression and Correlation of Breaker Gage Data with OBS and 10-m Gage Data for January 1992}

\begin{tabular}{|c|c|c|c|}
\hline \hline Data Sources & $\begin{array}{c}\boldsymbol{m} \\
\text { Slope of } \\
\text { Regression }\end{array}$ & $\begin{array}{c}\boldsymbol{b} \\
\text { Intercept } \\
\left(\mathbf{m}^{3} / \mathbf{h o u r}\right)\end{array}$ & $\begin{array}{c}\boldsymbol{r} \\
\text { Correlation } \\
\text { Coefficient }\end{array}$ \\
\hline \hline $\begin{array}{c}\mathrm{x} \text { is the breaker gage data } \\
\mathrm{y} \text { is the OBS data }\end{array}$ & -1.9268 & -38.7602 & -0.9397 \\
\hline $\begin{array}{c}\mathrm{x} \text { is the breaker gage data } \\
\mathrm{y} \text { is the shoaled } 10 \mathrm{~m} \text { data }\end{array}$ & 0.5869 & 11.5309 & 0.8735 \\
\hline Number of Spectra, $\mathrm{n}=14$. & & & \\
\hline
\end{tabular}

While both correlations are high, the correlation between the OBS data and the breaker line wave gage is negative. These results suggest that the problem is not a result of shoaling the wave data. However, there are insufficient data to draw firm conclusions. 


\section{Impoundment Basin and Dredging Measurements}

The initial dredging of the impoundment basin was completed in March 1990. Bathymetric surveys show that by the time of the second dredging in the fall of 1992 , the impoundment basin had almost completely filled and the channel was badly shoaling (see Figure 20). The survey data shown in Table 9 were used to establish the volumes of material within the impoundment basin at different times. Pairs of volumes and times were used to determine shoaling rates for the basin. The results are shown graphically in Figure 27; the infilling rate over various time intervals between the two dredging events. While every survey was done on several (or all) range lines, a few pairs of surveys had only a single overlapping range line. Since the basin did not fill completely uniformly, these survey pairs were not considered as reliable and were not plotted in Figure 27.

Figure 27 shows a series of horizontal lines that represent the average infilling rate over the time span indicated, as determined by the surveys at the endpoint dates. The jagged (dashed) line that slopes down to the right connects the midpoints of the horizontal lines. This diagonal line shows that just after dredging in early 1990 the infilling rate was just under 400,000 cubic meters/year, but that by the end of the year the rate had dropped to about half that amount, and a year later, to essentially zero. Thus, as the basin filled (became shallower), it became less efficient at retaining the sediment that entered it because the bottom was subjected to increasing wave and current forces.

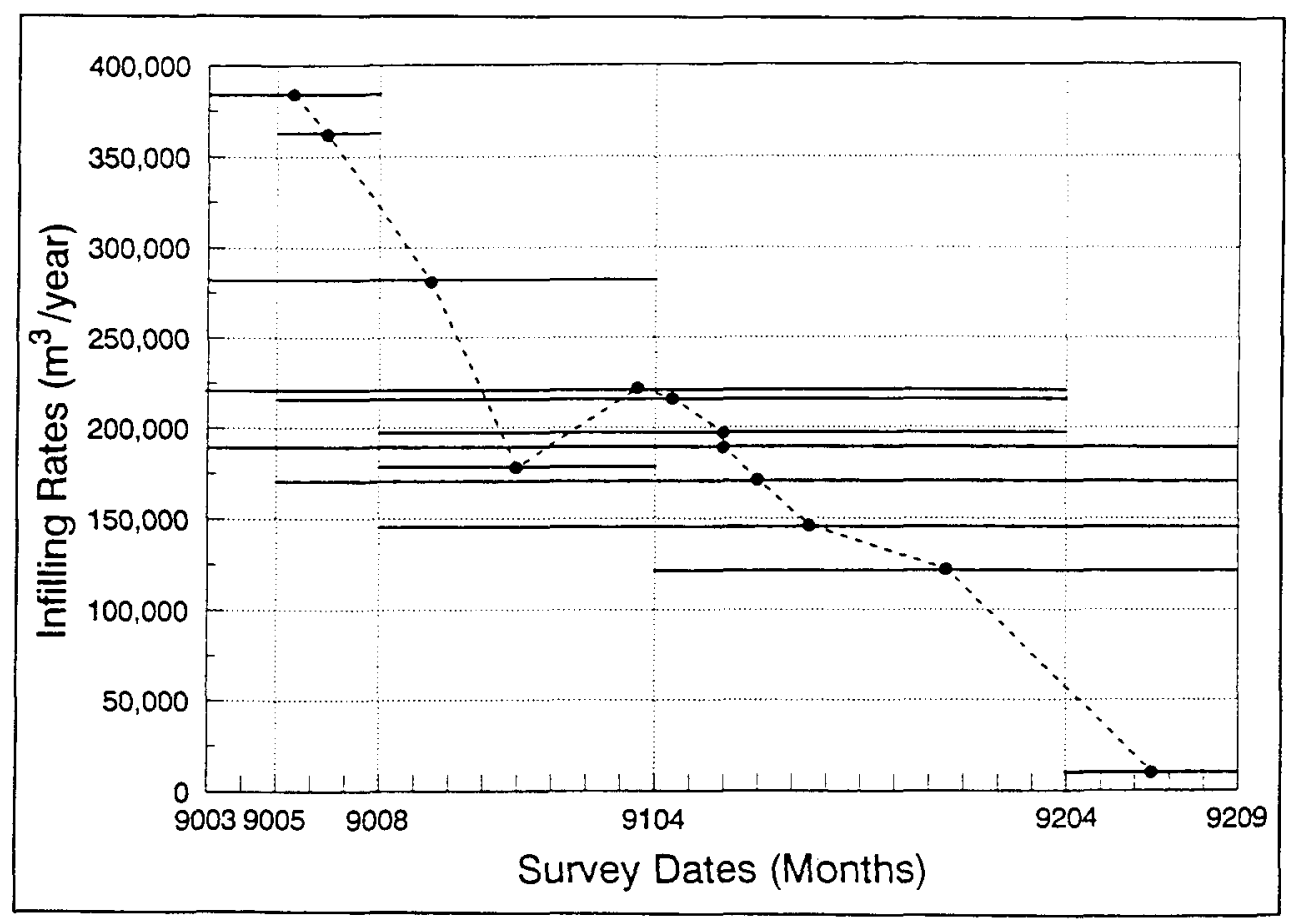

Figure 27. Plot of impoundment basin infilling rates 
Figure 27 indicates that the maximum infilling rate of the basin is around 400,000 cubic meters/year. However, even initially, the basin is not 100 percent efficient at trapping the sediment that enters it. If it were, the dashed line in Figure 27 would be expected to be shaped like a (backwards) lazy "S." It would start out as horizontal at the value of the transport rate. As the basin shoaled, at some point, the line would slope down to the right, and then as the basin completely filled, the infilling rate would approach zero and the line would again become horizontal. Thus, it is clear that substantially more than 400,000 cubic meters of material enters the basin yearly.

However, the sediments deposited in the impoundment basin are a mix of river and beach sediments. The river does carry a substantial sediment load. In the past, an average of 371,000 cubic meters of material has been removed yearly from a settling basin upstream of the Gulf Intracoastal Waterway (U.S. Army Engineer District, Galveston 1977). Even though the river has been diverted into Matagorda Bay upstream of its mouth, grain size analysis indicates that significant volumes of riverine material continue to reach the coast.

The volumes of material dredged from the impoundment basin and entrance channel are shown in Table 8. In the 5-year interval following the first dredging event (March 1990 to February 1995) more than 2,000,000 cubic meters of material were removed in three major dredging operations, with about equal parts coming from the entrance channel and impoundment basin. This averages to 430,000 cubic meters/year. Part of this material may have come from the offshore bar which was at the mouth prior to jetty construction and/or prior to river diversion. If so, infilling rates in the impoundment basin would be expected to diminish in the future.

However, it appears likely that the large majority of this material is carried to the area by longshore transport down the beach or by riverine transport. Thus, it is prudent to consider that 430,000 cubic meters is approximately the amount that will need removal on a yearly basis. Taking averages of the sediment samples, 75 percent of the accumulation in the entrance channel and 55 percent of the accumulation in the impoundment basin can be assumed to be derived from longshore drift. This would imply that of the 430,000 cubic meters/year average accumulation, about 280,000 cubic meters/year is from the littoral drift and the remainder, 150,000 cubic meters/year, is supplied by the river. Thus, from this conservative estimate, the long-shore transport rate can be assumed to be in excess of 280,000 cubic meters/year.

\section{Summary}

In Table 11, the longshore transport estimates based upon some change in bathymetry are in general substantially less than the transport estimates based upon wave data. Both techniques have flaws. Unless some shoreline feature acts as a total block to the longshore transport, a bathymetry-based technique 
will underpredict the transport rate. Predictions based upon wave data rely on an imperfect understanding of the relationship of wave energy flux and longshore transport rate.

At the Colorado River, it is clear that the impoundment basin and channel are not functioning as a total sink. This is observed in the pattern of sediment deposition shown in Figure 27. Thus, the wave-based transport rates presented by Heilman (1995) and in this report (gross transport in the range of 600,000 to 700,000 cubic meters/year and net transport in the range of 300,000 to 500,000 cubic meters/year) are consistent with the impoundment basin data, and are the best available estimates of longshore transport at this location. 


\section{Evaluation of Project Design}

\section{General Discussion}

Most of the data presented in this report were collected within the period 1990 to 1992 . This time frame is after completion of the jetties and impoundment basin, but just prior to the diversion of the Colorado River flow into west Matagorda Bay. This diversion may have a significant impact on the hydrodynamics and sediment dynamics at the mouth of the river. Thus, some of the conclusions drawn from this data set may not be useful for long-term forecasting of conditions at the mouth of the Colorado River.

The principal flaw in the Colorado River weir jetty system design was the substantial underestimation of the longshore transport rate. This led to a clearly inadequate design for the impoundment basin, and to a lesser extent, to a general underdesign of several parts of the system. To operate effectively, the impoundment basin should be dredged more frequently than called for in the design (once every 2 years) or the size of the impoundment basin should be substantially enlarged. Unfortunately, not much room is available to enlarge the impoundment basin.

If the primary purpose of the project were to have minimal impact on the adjacent beaches, then the project could have been judged a success. However, as stated on page 1 of the General Design Manual:

The primary purpose of the authorized project is to provide safe and dependable navigation between the Gulf of Mexico and the Gulf Intracoastal Waterway.

(U.S. Army Engineer District, Galveston 1977).

Shoals form in the entrance channel between dredging events, making navigation hazardous. Jetties that were wider apart would have allowed for a larger impoundment basin, and thus, less shoaling. Longer jetties would also have decreased the shoaling problem. However, these changes would have caused greater impacts on the adjacent beaches.

In spite of these flaws, some aspects of the design have worked well, as discussed below. 


\section{Test of Hypotheses}

To analyze various parts of the weir jetty system, the monitoring program was designed to address the specific hypotheses introduced in Chapter 3 . The results of the analyses to test these hypotheses are given below.

a. Hypothesis No. 1: The weir-jetty system has minimal impact on adjacent beaches. The time frame of 1984 to 1990 encompasses the building of the jetties at the mouth of the river. During this time, over the first $3 \mathrm{~km}$ updrift of the inlet, the shoreline position prograded an average of $20 \mathrm{~m}$. Then, between 1990 and 1992, the shoreline eroded an average of $6.5 \mathrm{~m}$. These data and a numerical model by Heilman (1995) indicate that the shoreline adjustment to the presence of the jetties has been relatively minor. Thus, the weir-jetty system has had minimal impact on the adjacent beaches.

b. Hypothesis No.2: The weir and impoundment basin should be on the northeast side of the inlet. Analysis of the wave data indicates that the strongly predominant sediment transport direction is to the southwest (see Figures 13 and 14). This is in agreement with other published information, including: Watson (1968), McGowen and Brewton (1975), and Heilman (1995). Thus, the proper location for the weir and impoundment basin is on the northeast side of the inlet.

c. Hypothesis No. 3: The weir is in the proper cross-shore location, is at the correct elevation, and is the proper length. Visual observations during the field experiments showed that the active portion of the surf zone (the breaker zone) approximately coincided with the weir section of the jetty. The fact that this occurred without a major adjustment of the shoreline position indicates that the weir was properly located. In addition, analysis of the profiles across the impoundment basin showed that the basin filled reasonably uniformly, with only somewhat more rapid filling at the landward end. This also indicates that the weir is in the proper location and is of the proper length. Attempts to measure the cross-shore divergence of the longshore transport rate during the field experiments did not yield conclusive results. Thus, quantitative support for this conclusion is not available; however, qualitatively, the weir appears to have been properly designed.

Concern has been expressed that the sill depth of the weir is too low and that this has led to excessive infilling of the impoundment basin. It is true that if the elevation were raised, the impoundment basin would fill at a slower rate. However, the sand not trapped in the basin would still go somewhere. It would either cause the upstream beach to prograde, or it would lead to faster shoaling around the jetty tips. The fact that the beach is fairly stable near the weir suggests that the sill depth is at the proper elevation.

\section{d. Hypothesis No.4: The impoundment area is large enough and the} anticipated dredging frequency is correct. Prior to jetty construction, the littoral drift rate was estimated to be 230,000 cubic meters/year, and the 
impoundment basin was designed to hold a 2-year supply of sediment, 460,000 cubic meters (U.S. Army Engineer District, Galveston 1977). After construction, it was found that the impoundment basin filled and the navigation entrance channel shoaled substantially more rapidly than expected. Analysis of data collected for this monitoring program indicates that the beaches around the mouth of the Colorado River have a gross littoral drift transport rate of the order of 670,000 cubic meters/year, and a net littoral drift transport rate of the order of 510,000 cubic meters/year to the southwest. In addition, river-borne sediments are also deposited in the impoundment basin. Thus, the impoundment basin is less than half as large as needed for a 2-year dredging cycle to be adequate.

e. Hypothesis No. 5: The impoundment basin trapping efficiency is high. Analysis of elevation profiles taken across the impoundment basin indicates that its trapping efficiency does not approach 100 percent and that the efficiency continuously decreases as the basin fills. The major accumulation of sediment in the entrance channel, estimated at more than 200,000 cubic meters/year, also indicates that substantial quantities of sediment are not trapped in the impoundment basin. Thus, the impoundment basin trapping efficiency is not high.

f. Hypothesis No. 6. The northeast jetty length should extend $460 \mathrm{~m}$ past the end of the weir section (to the -3.7-m contour). The original experiment plan called for making sediment transport measurements at the tip of the northeast jetty. However, this was not possible due to hazardous waves and currents at this location. However, the major shoaling problems appear to be in the entrance channel between the jetties, rather than on a bar off the tip of the jetties. This would indicate that the major sediment pathway was through the weir and impoundment basin and then around the southwest jetty to the downstream beach, rather than around the tips of both jetties. Thus, from that standpoint, the northeast jetty length is satisfactory. However, a longer northeast jetty would help decrease the shoaling in the entrance channel by forcing the shoals to form in deeper water. 


\section{Discussion and Recommendations}

\section{Management of the Mouth of the Colorado River}

As discussed above, the principal management problem at the MOCR is caused by the inadequate size of the impoundment basin and its inefficiency in retaining sediments. The response of SWG to date has been to increase the frequency of the dredging schedule to approximately yearly. This is an effective strategy, but other strategies may be more cost-effective and should be considered.

Total dredging costs may be decreased if the impoundment basin is enlarged. There is some, but not a great deal of, area available between the two jetties to enlarge the surface area of the impoundment basin. One possibility would be to widen the basin to include the navigation channel within it. Surveys show that the impoundment basin fills from the weir side first, so the channel portion should be the last to fill. When the basin fills, it would shoal the navigation channel, but that happens now. The larger basin volume would delay the shoaling time. Surveys show that in the present configuration, the channel occasionally migrates and runs through the impoundment basin.

Another possibility is to extend the basin landward so that it encroaches on the portion of the beach that is inside the northeast jetty. This is a logical location to increase the impoundment basin size because the basin filled somewhat more rapidly at its shoreward end (Table 9). However, there are safety concerns for swimmers associated with locating a deep dropoff next to shore. There is also a little room to enlarge the basin along its seaward edge.

The impoundment basin could also be somewhat deepened. This would not only provide greater storage capacity, but should also improve its efficiency at retaining sediments, at least shortly after dredging. Doubling the depth would only increase the volume by about 75 percent due to the effect of the 1:5 side slopes, so the best alternative may be to increase both the depth and the surface area. 
At this time it is probably too early to seriously consider more drastic solutions such as a redesign of the jetties. However, this may need to be considered as part of long-range plans. Such a redesign should allow for the impoundment basin to be enlarged in size and physically isolated from the river-borne sediments.

The area should continue to be monitored by the district. A regular program of beach profile measurements should be taken once every 1 to 2 years for the next decade or so, to determine if long-term changes are occurring near the mouth. The offshore bathymetry near the mouth should also be occasionally monitored to determine the ebb shoal bar response to the jetties.

\section{Lessons Learned for Future Weir Jetty Designs}

a. Good, reliable estimates of the longshore transport rate are needed prior to jetty and impoundment basin design. The current recommended method is to compute the long-shore transport rate from at least 2 years of onsite wave data. Failure to have this will lead to uncertainties in anticipated dredging costs, and may lead to poor choices in jetty and impoundment basin design.

$b$. Prior weir jetty systems have been located at inlets that typically have minimal amounts of inland-derived sediments. This was not the case at the Colorado River. In future weir jetty designs at river mouths that carry large sediment loads, both beach and river sediments must be taken into consideration. If the river-borne sediments are expected to pass through the system without creating substantial shoaling problems, care should be taken to situate the impoundment basin so that minimal trapping of the river-borne sediments occurs. This could be done through the use of retaining dykes, by physically separating the basin from the river mouth, or by other creative approaches.

c. It is important for the project design to have flexibility to allow for modifications of the size and shape of the impoundment basin based on operational experience. 


\section{References}

Aronow, S., and Kaczorowski, R. T. (1985). Texas, the world's coastline. van Nostrand Reinhold, New York, 129-146.

Beach, R. A. (1995). "Longshore suspended sediment transport at the mouth of the Colorado River, Matagorda, Texas," Contract Report CERC-95-3, U. S. Army Engineer Waterways Experiment Station, Vicksburg, MS.

Beach, R.A., Sternberg, R. W., and Johnson, R. (1992). "A fiber optic sensor for monitoring suspended sediment," Marine Geology 103, 513-520.

Birkemeier, W. A. (1984). "A User's Guide to ISRP: The interactive survey reduction program," Instruction Report CERC-84-1, U.S. Army Engineer Waterways Experiment Station, Vicksburg, MS.

Bodine, B. R. (1969). "Hurricane frequency estimated for the Gulf Coast of Texas," Technical Memorandum 26, Coastal Engineering Research Center, U.S. Army Engineer Waterways Experiment Station, Vicksburg, MS.

Downing, J. P., Sternber, R. W., and Lister, C. R. B. (1981). "New instrumentation for the investigation of sediment suspension processes in the shallow marine environment," Marine Geology 42, 19-34.

Galvin, C.J. (1979). "Relation between immersed weight and volume rates of longshore transport," Technical Paper 79-1, Coastal Engineering Research Center, U.S. Army Engineer Waterways Experiment Station, Vicksburg, MS.

Galvin, C.J., and Schweppe, C. R. (1980). "The SPM energy flux method for predicting longshore transport rate," Technical Paper 80-4, U.S. Army Engineer Waterways Experiment Station, Vicksburg, MS.

Hanson, H., and Kraus, N.C. (1989). "GENESIS: Generalized model for simulating shoreline change; Report 2, Workbook and system user's manual," Technical Report CERC-89-19, U.S. Army Engineer Waterways Experiment Station, Vickburg, MS.

Headquarters, Department of the Army (1993). "Engineering and design; monitoring coastal projects," Engineering Regulation 1110-2-8151, U.S. Government Printing Office, Washington, DC.

Heilman, D.J. (1995). “The effects of the Colorado River Project on longshore sediment transport at Matagorda Peninsula, Texas, M.S. thesis, Texas A\&M University, College Station, TX. 
Heilman, D.J., and Edge, B. L. (1996). "The effects of the Colorado River project on long-shore sediment transport," Book of Abstracts, 25th International Conference on Coastal Engineering, 772-773.

Howell, G. L. (1992). "A new nearshore directional wave gage." Proceedings, 23rd International Conference on Coastal Engineering. American Society Civil Engineers, Venice, Italy, 295-307.

Hubertz, J.M., and Brooks, R. M. (1989). "Gulf of Mexico hindcast wave information," WIS Report No. 18, U.S. Army Engineer Waterways Experiment Station, Vicksburg, MS.

Kraus, N.C., Gingerich, K. J., and Rosati, J. D. (1989). "DUCK85 surf zone sand transport experiment," Technical Report CERC-89-5, U.S. Army Engineer Waterways Experiment Station, Vicksburg, MS.

Lacey, M. L. (1990). "Colorado River, Texas, reduced data; May 4-7," unpublished report, U. S. Army Engineer Waterways Experiment Station, Vicksburg, MS.

Liang, G. (1995). "Shoreline and sediment volume changes at the Colorado River mouth, Texas," Contract Report CERC-95-2, U. S. Army Engineer Waterways Experiment Station, Vicksburg, MS.

Longuet-Higgins, M. S., Cartwright, D. E., and Smith, N. D. (1963). Observations of the directional spectrum of sea waves using the motions of a floating buoy, ocean spectra. Prentice-Hall, Inc., Englewood Cliffs, NJ, 111-136.

Mason, C. (1981). "Hydraulics and stability of five Texas inlets," Miscellaneous Report 81-1, U.S. Army Engineer Waterways Experiment Station, Vicksburg, MS.

Mason, C., and Sorenson, R. M. (1971). "Properties and stability of a Texas barrier beach inlet," Sea Grant Publication No. TAMU-SG-71-217, Texas A\&M University, College Station, TX.

McGowen, J. H., and Brewton, J. L. (1975). "Historical changes and related coastal processes, gulf and mainland shorelines, Matagorda Bay area, Texas," Bureau of Economic Geology, The University of Texas at Austin.

Morton, R.S., Peiper, M. J., and McGowen, J. H. (1976). “Shoreline changes on Matagorda Peninsula (Brown Cedar Cut to Pass Cavallo): An analysis of historical changes of the Texas Gulf shoreline,"Geological Circular 76-6, Bureau of Economic Geology, University of Texas at Austin, Austin, TX.

Paine, J.G., and Morton, R. A. (1989). "Shoreline and vegetation-line movement, Texas Gulf coast, (1974-1982)," Geological Circular 89-1, Bureau of Economic Geology, University of Texas at Austin. 
Schneider, C. (1981). The Littoral Environment Observation (LEO) Data Collection Program," Coastal Engineering Technical Aid CETA 81-5, U.S. Army Engineer Waterways Experiment Station, Vicksburg, MS.

Shore protection manual. (1984). 4th ed., 2 Vol, U.S. Army Engineer Waterways Experiment Station, U.S. Government Printing Office, Washington, DC.

Sommerfeld, B. G., Mason, J. M., Kraus, N. C., and Larson, M. (1994). "BFM: Beach Fill Module; Report 1: Beach morphology analysis package (BMAP); user's guide," Technical Report CERC-94-1, U.S. Army Engineer Waterways Experiment Station, Vicksburg, MS.

Thomas, L.J. (1994). "User's guide for the Littoral Environment Observation (LEO) PC data retrieval and analysis system," Instruction Report CERC-94-2, U.S. Army Engineer Waterways Experiment Station, Vicksburg, MS.

U.S. Army Engineer District, Galveston. (1977). "Mouth of Colorado River Texas; Phase I, general design memorandum (navigation features)," Galveston, TX.

U.S. Department of Commerce. (1987). "Freshwater inflow needs of the Matagorda bay system with focus on Penaeid shrimp," NOAA Technical Memorandum NMFS-SEFC-189, Galveston, TX.

. (1990). "Tidal current tables: Atlantic coast of North America,"National Oceanic and Atmospheric Administration, National Ocean Service, Rockville, MD.

Watson, R.L. (1968). "Origin of shell beaches, Padre Island, Texas," M.S. thesis, University of Texas at Austin.

Watson, R.L., and Behrens, E. W. (1976). "Hydraulics and dynamics of New Corpus Christi Pass, Texas: A case history, 1973-1975," GITI Report 9, U.S. Army Engineer Waterways Experiment Station, Vicksburg, MS.

White, T. E. "MCCP Colorado River sediment flux computations," unpublished Project Memorandums and files, 3 Vol, U.S. Army Engineer Waterways Experiment Station, Vicksburg, MS.

(1994). "Field tests of radiation-stress estimators of long-shore sediment transport." Proc. 24th International Conference on Coastal Engineering. American Society of Civil Engineers, 2799-2812. 


\section{Appendix A Monthly Percent Occurrence of Wave Height and Period}

In the following tables, a small percentage of the wave heights were below a $0.2-\mathrm{m}$ threshold. Wave periods are not reliable for these small amplitudes, so they were excluded from the statistical analysis. Thus, the number of monthly data points given in these tables is usually less than the number indicated in Chapter 3, Table 2. 


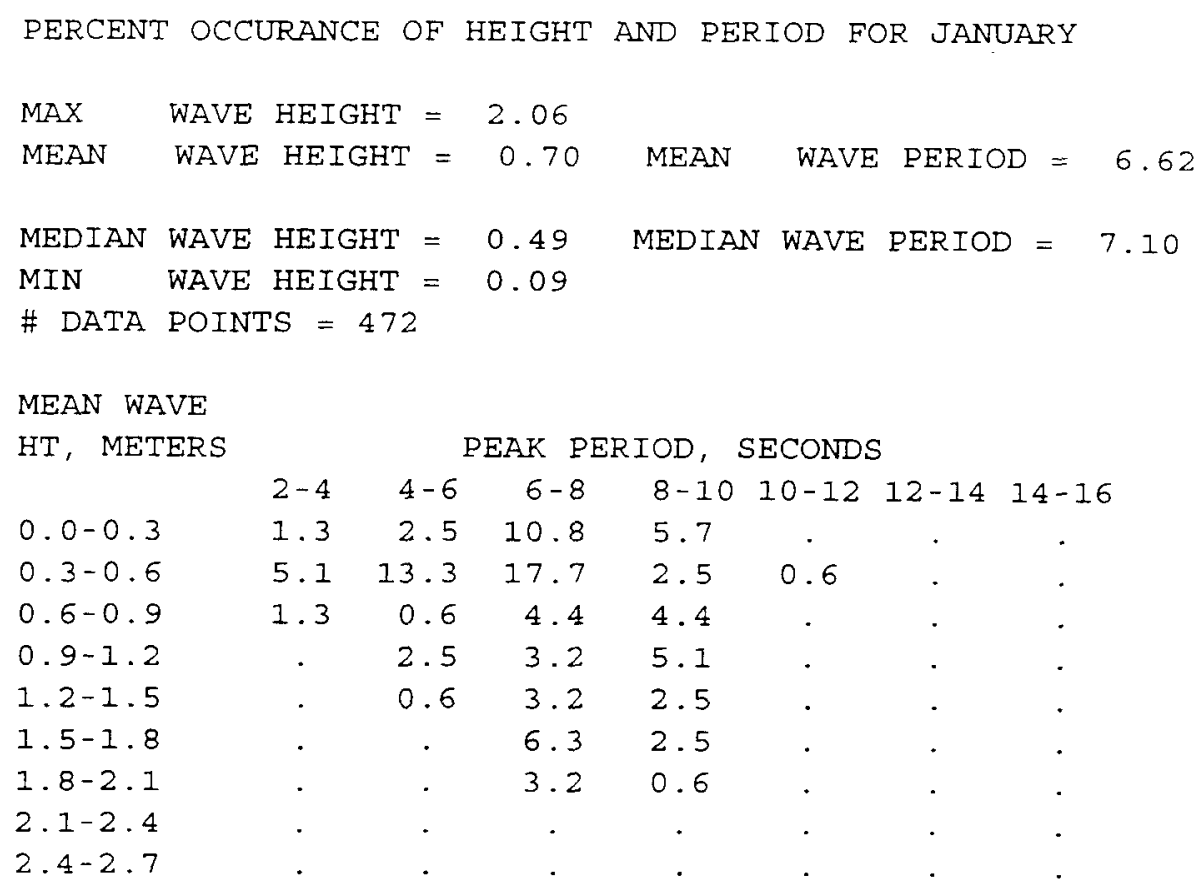




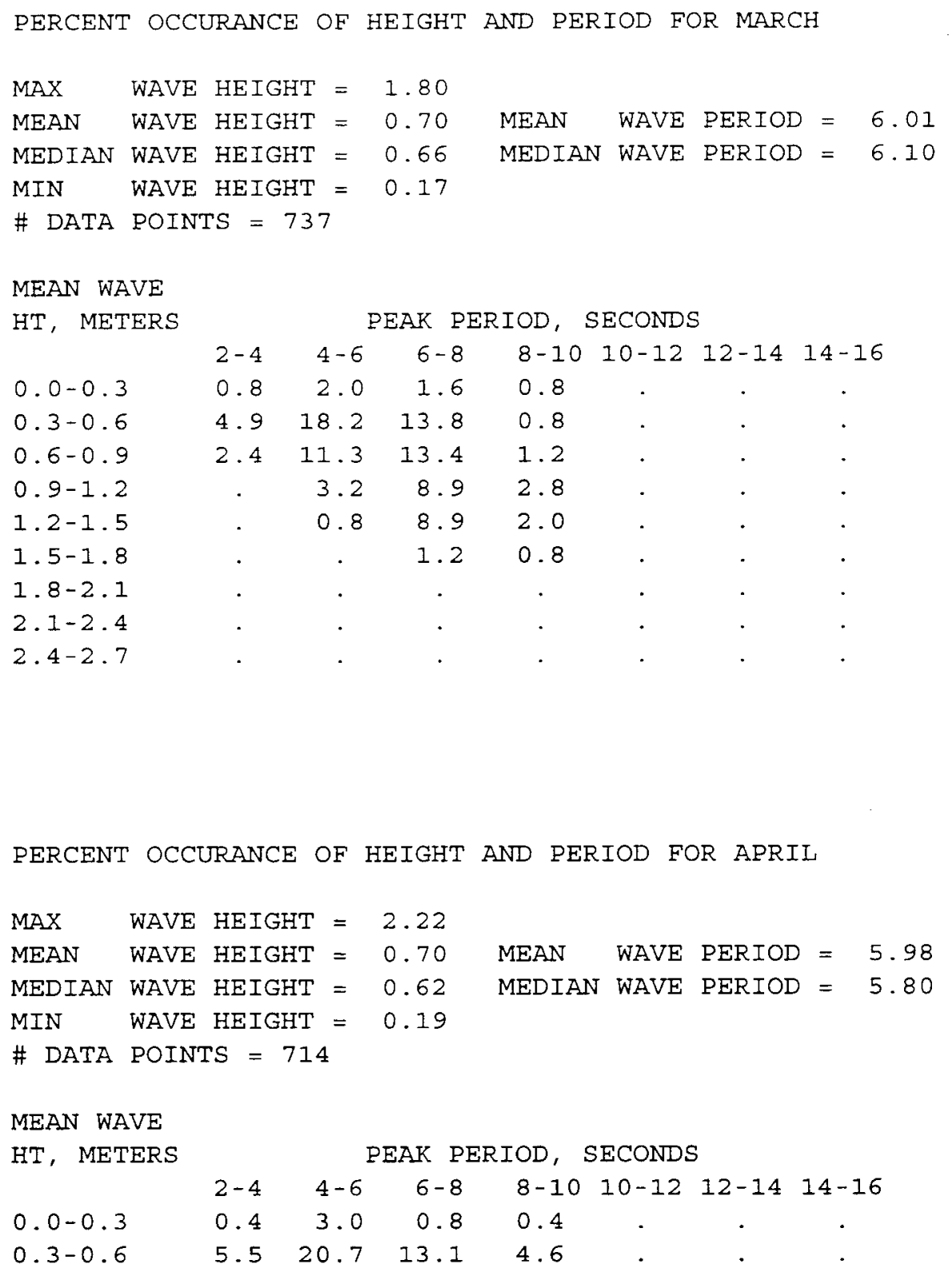




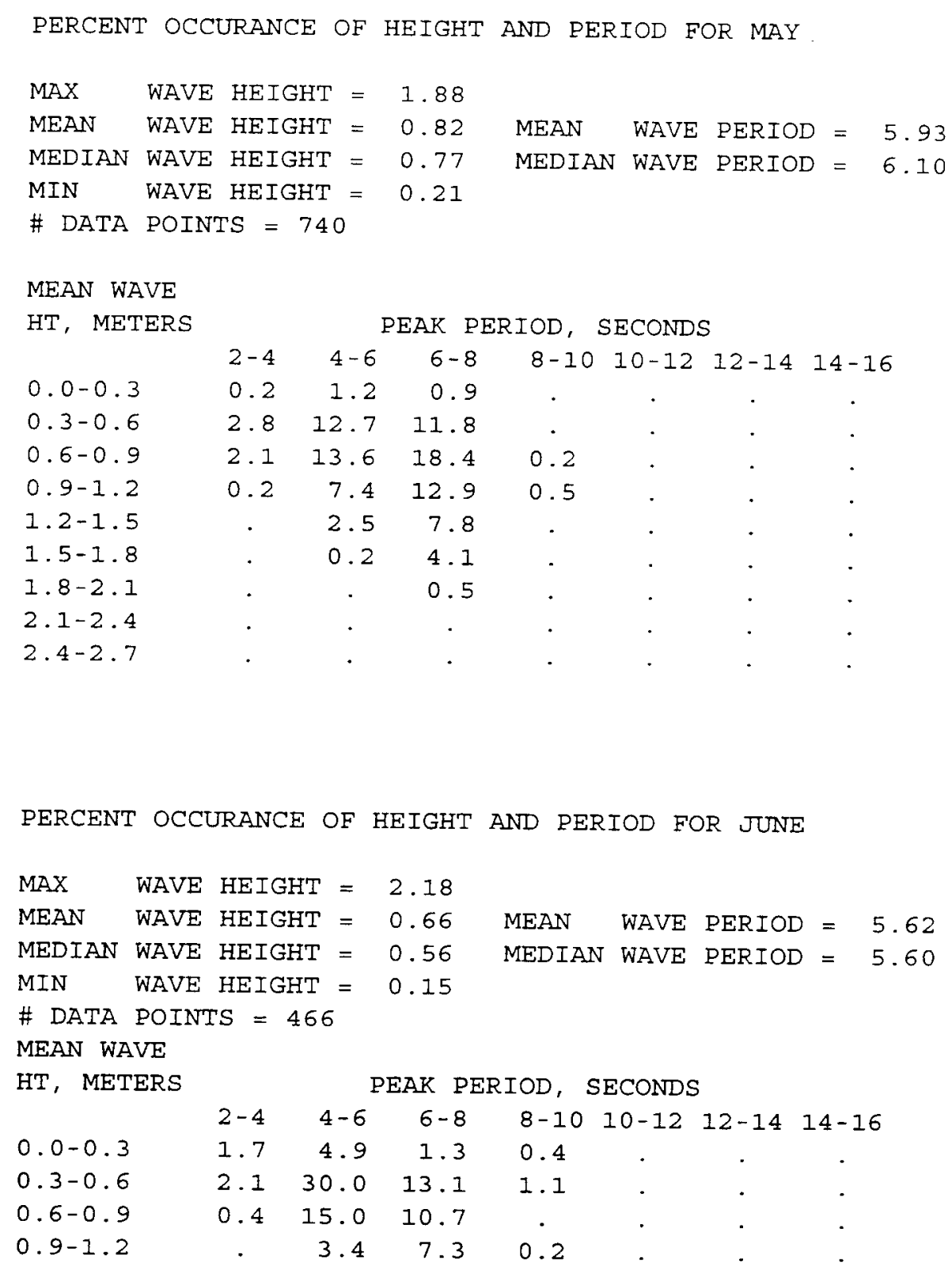




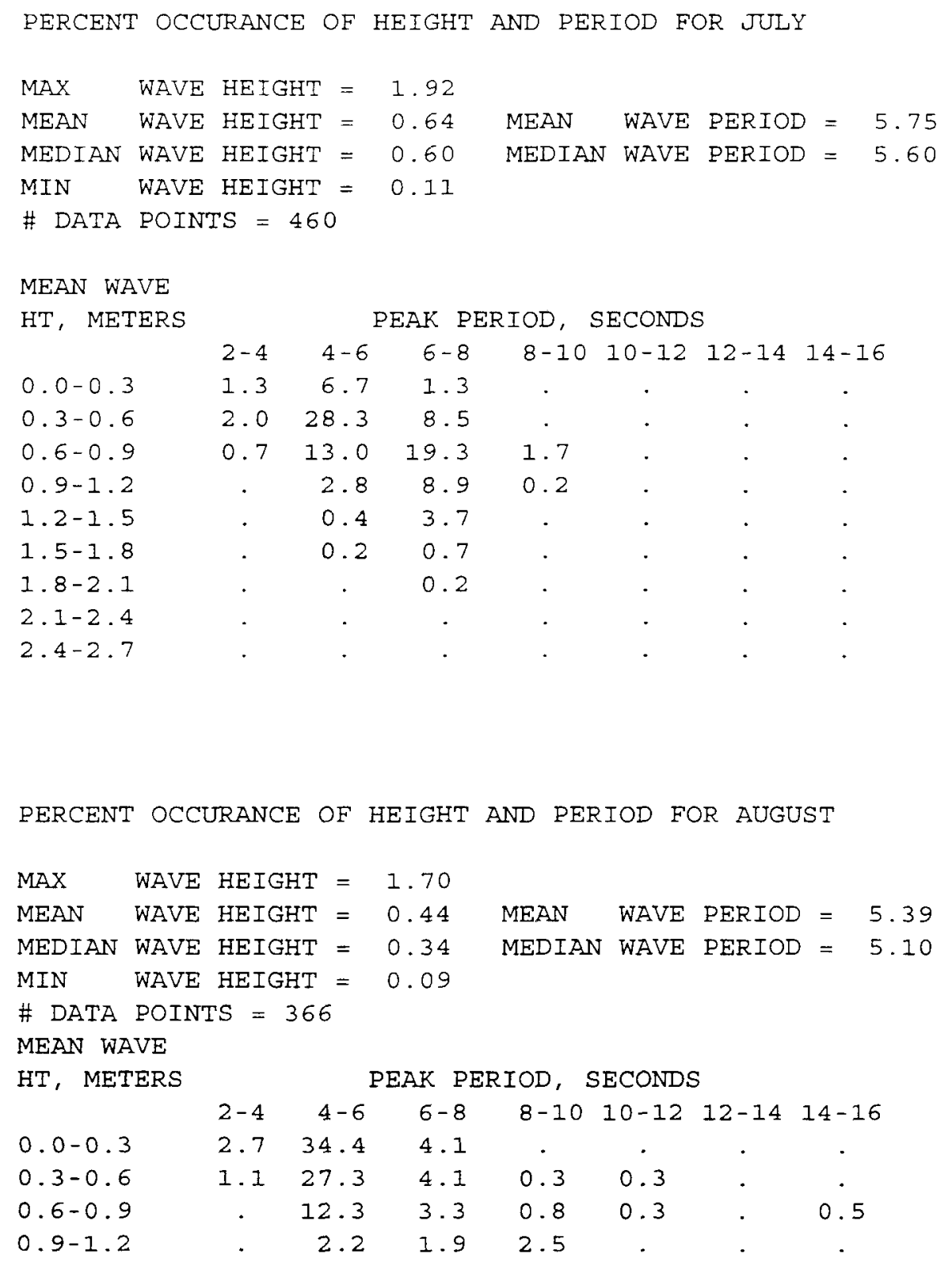




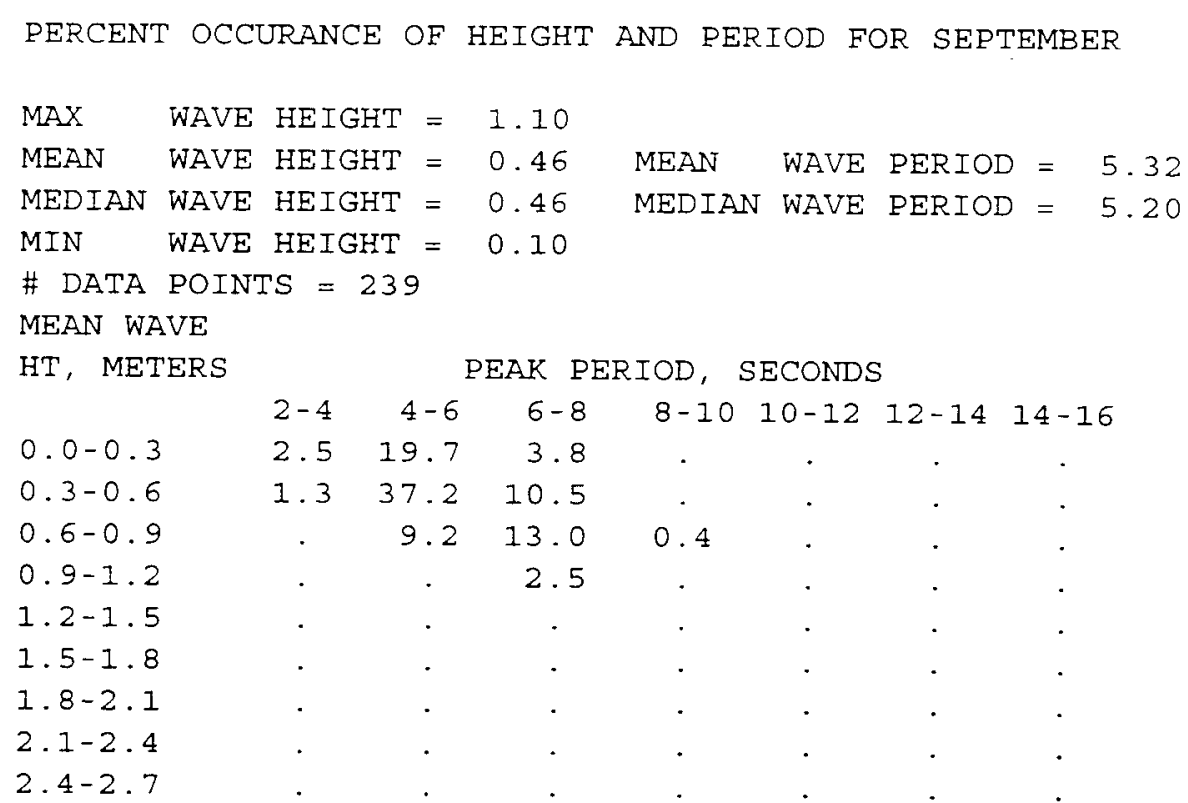




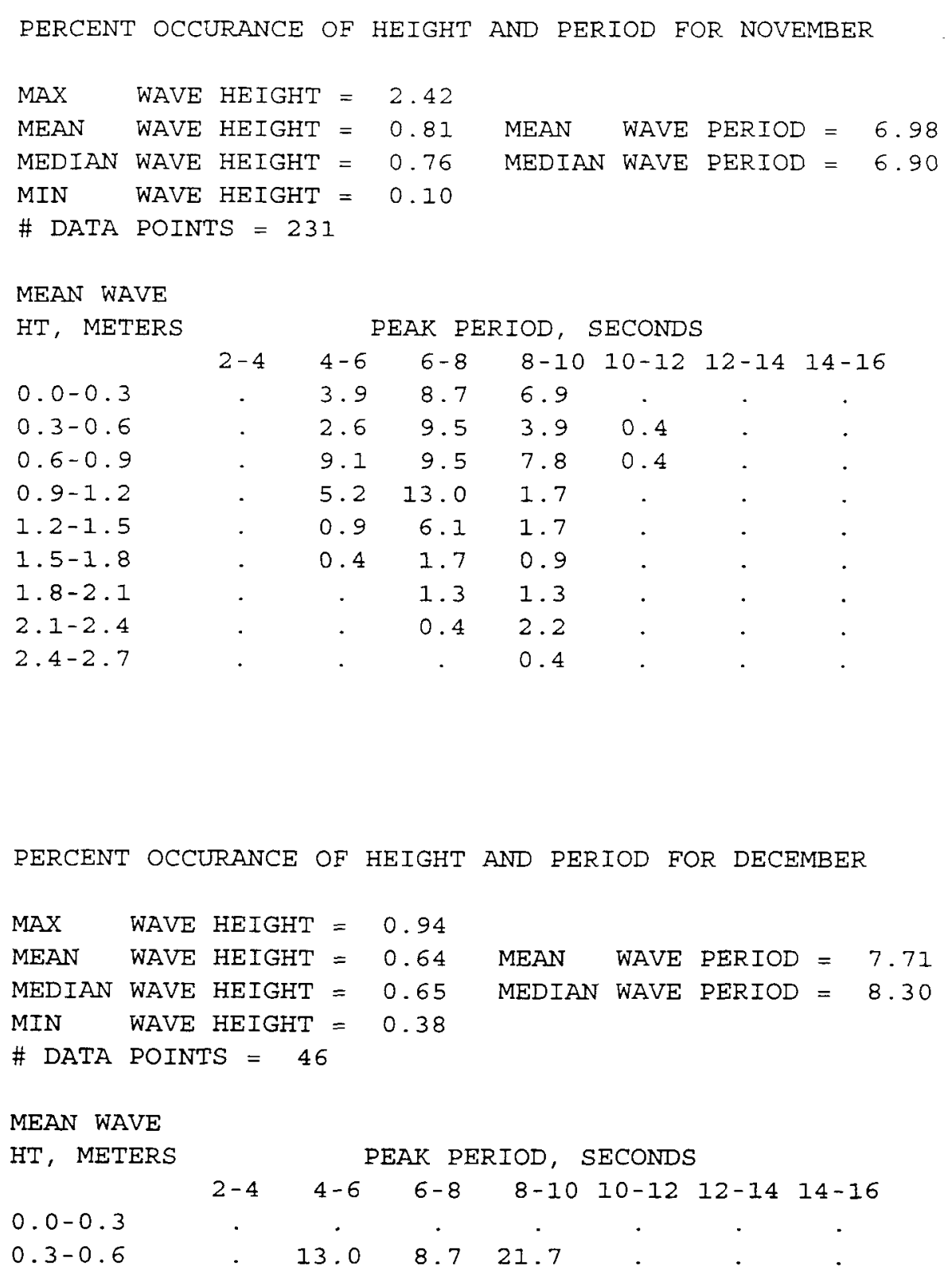




\section{Appendix B Summary of All Wave Heights, Periods, and Directions}




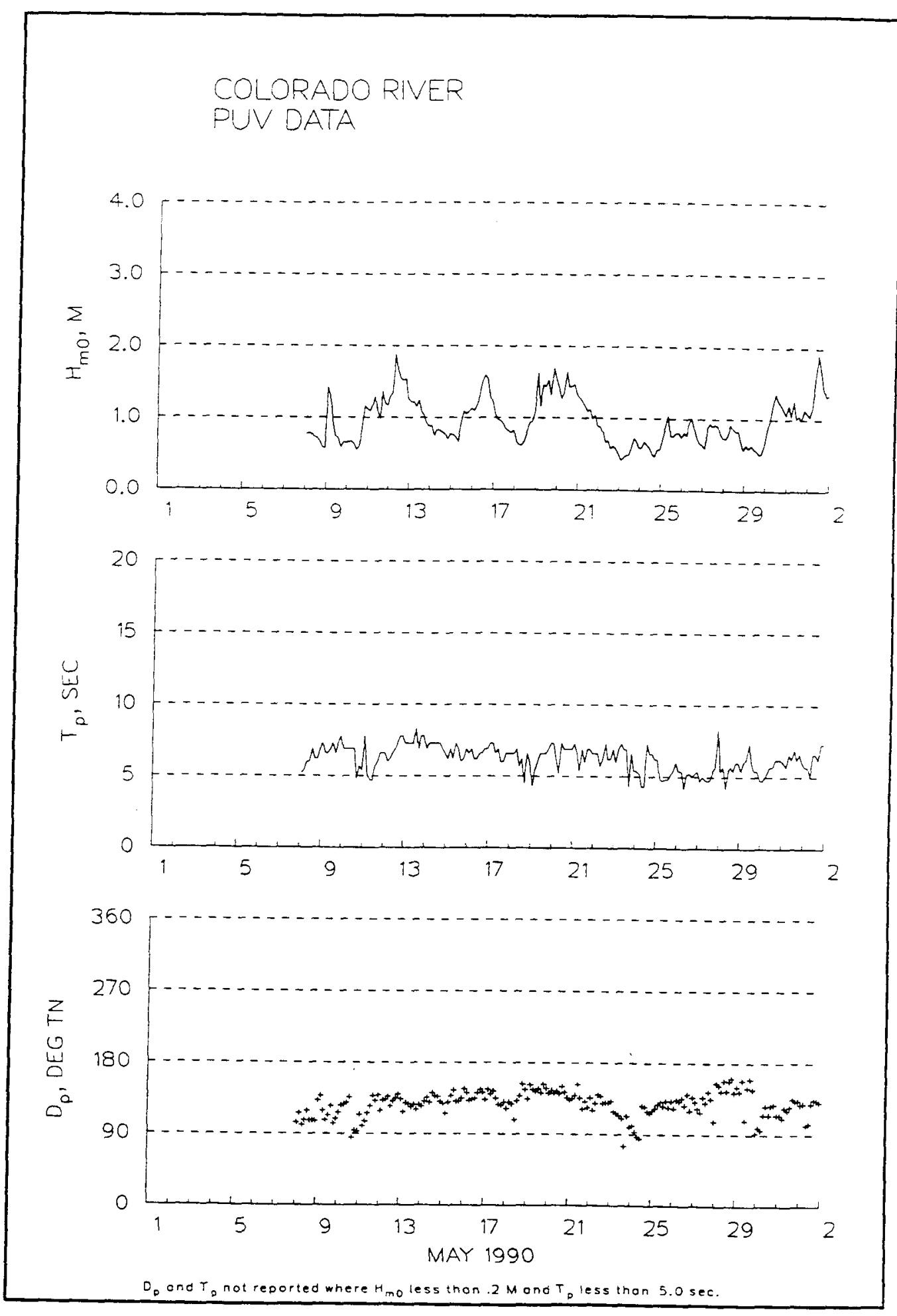




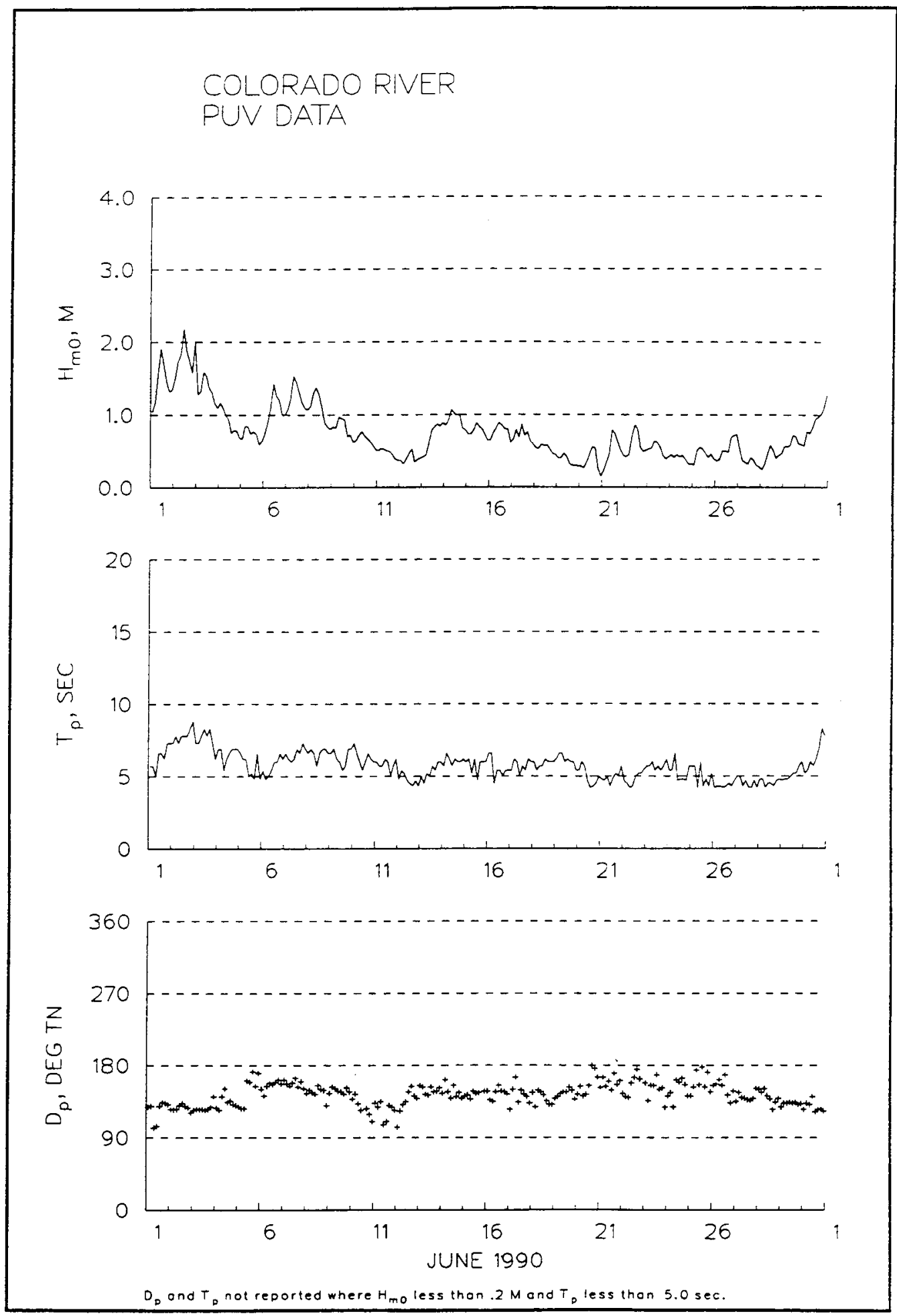




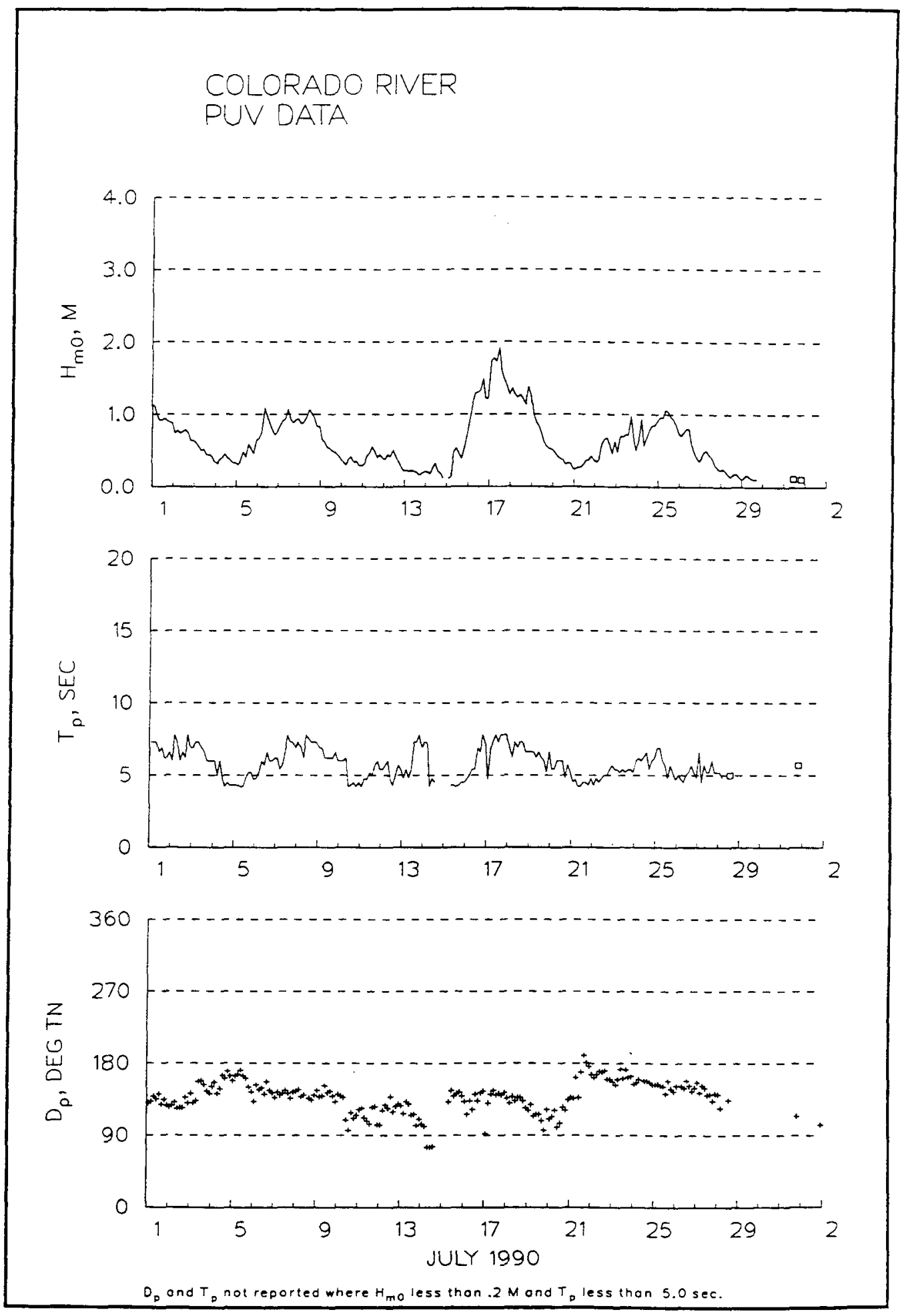




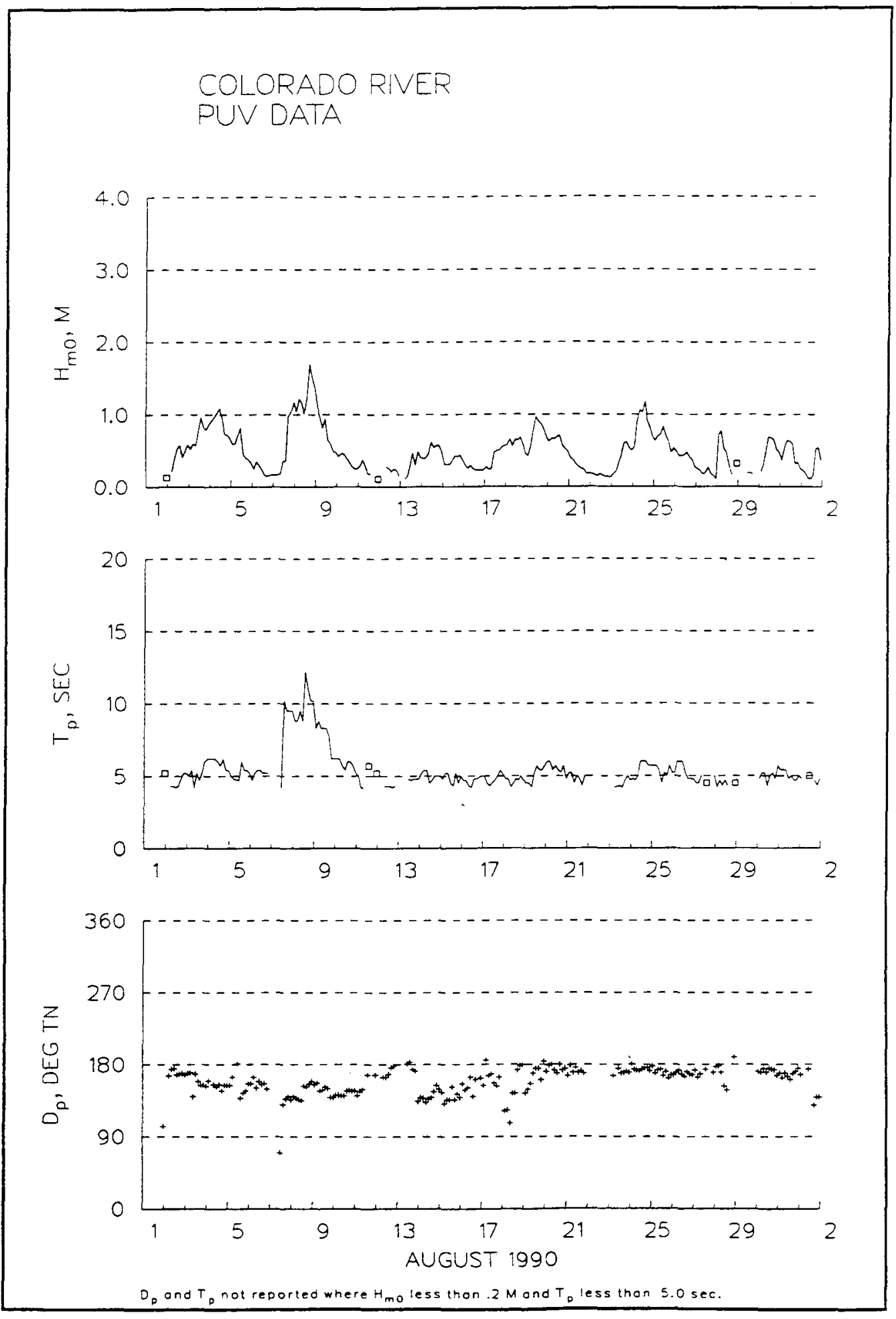




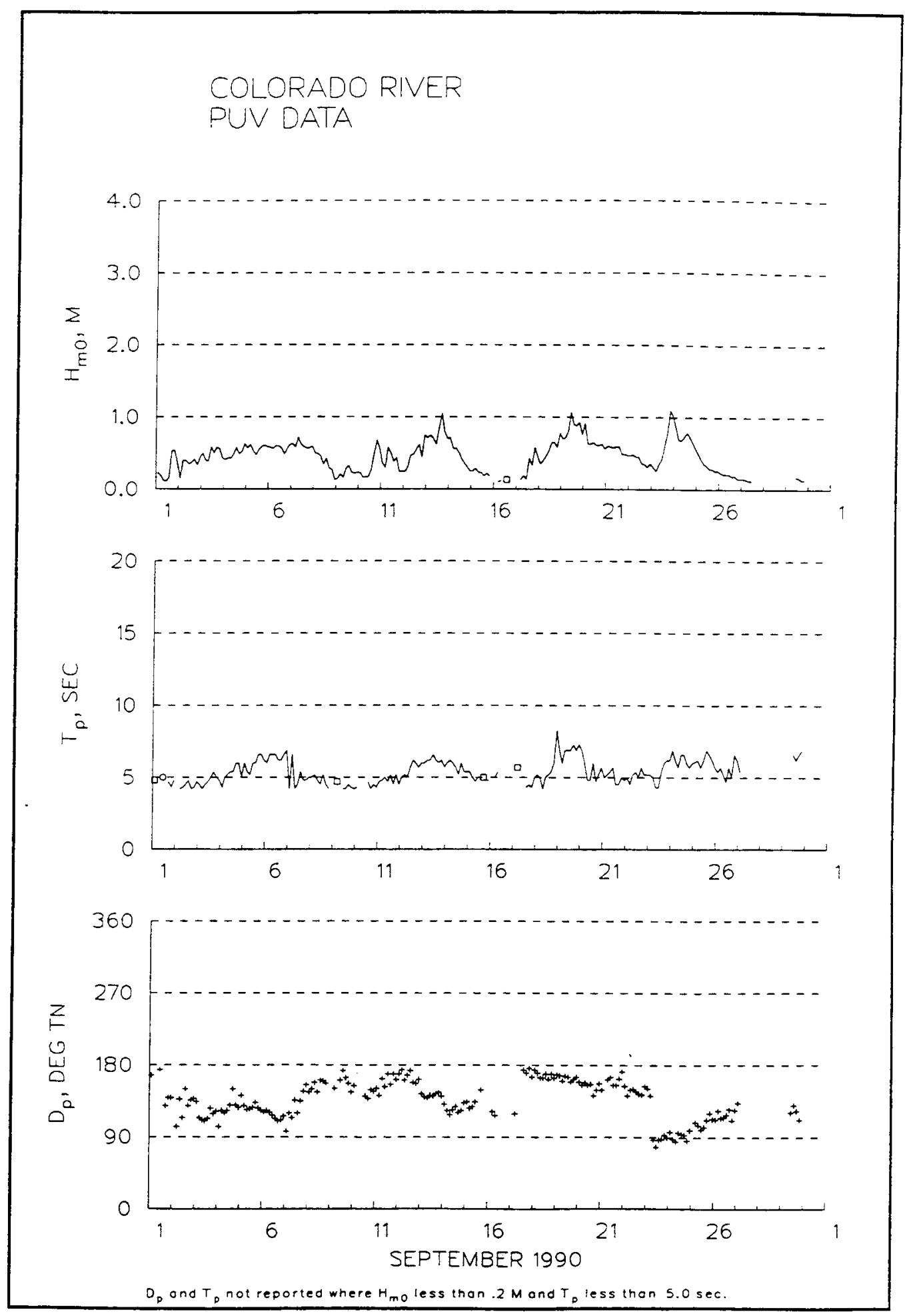


COLORADO RIVER

PUV DATA
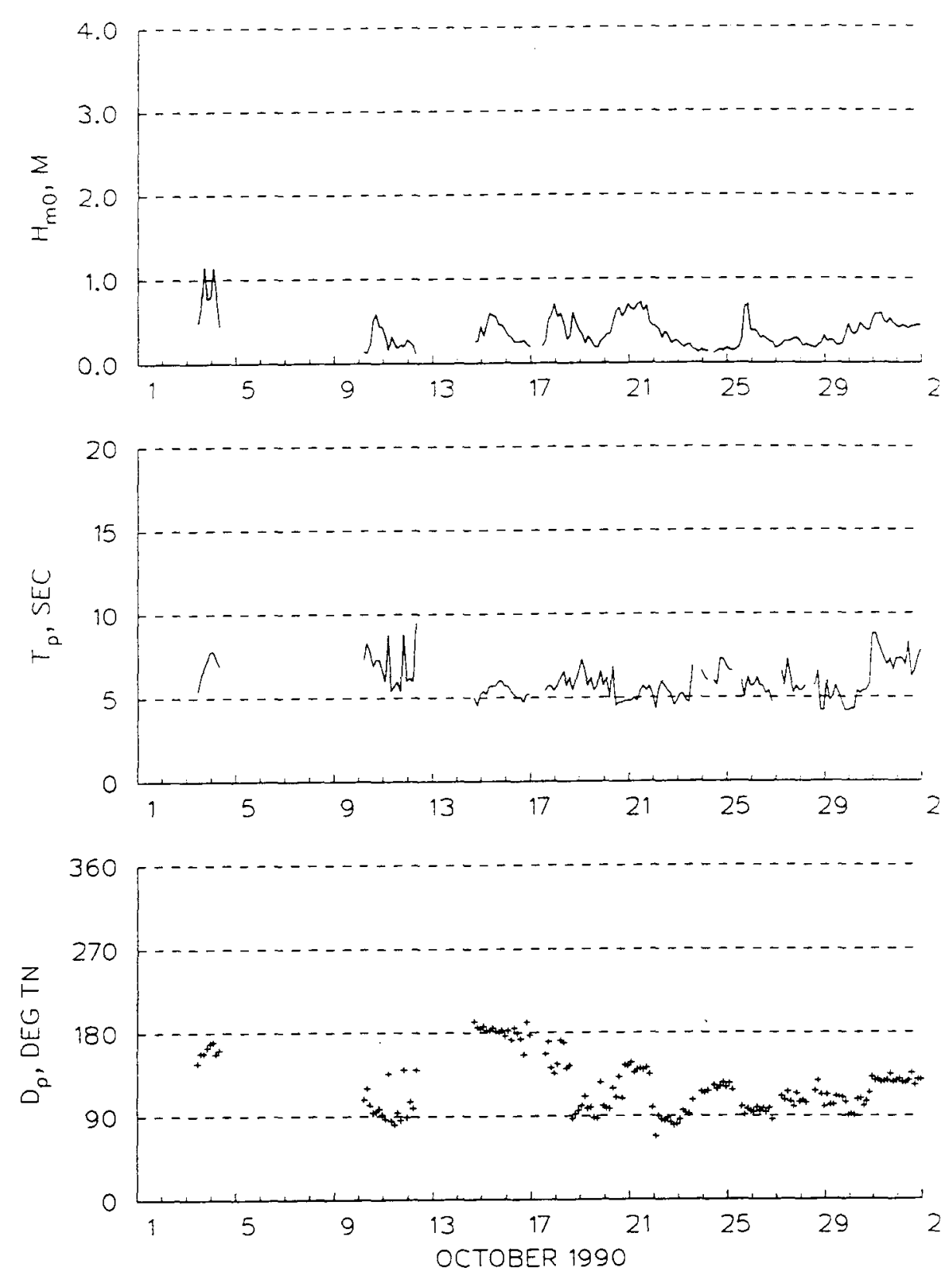

$D_{p}$ ond $T_{p}$ not reported where $H_{m o}$ less than $2 \mathrm{M}$ and $T_{p}$ less thon 5.0 sec. 


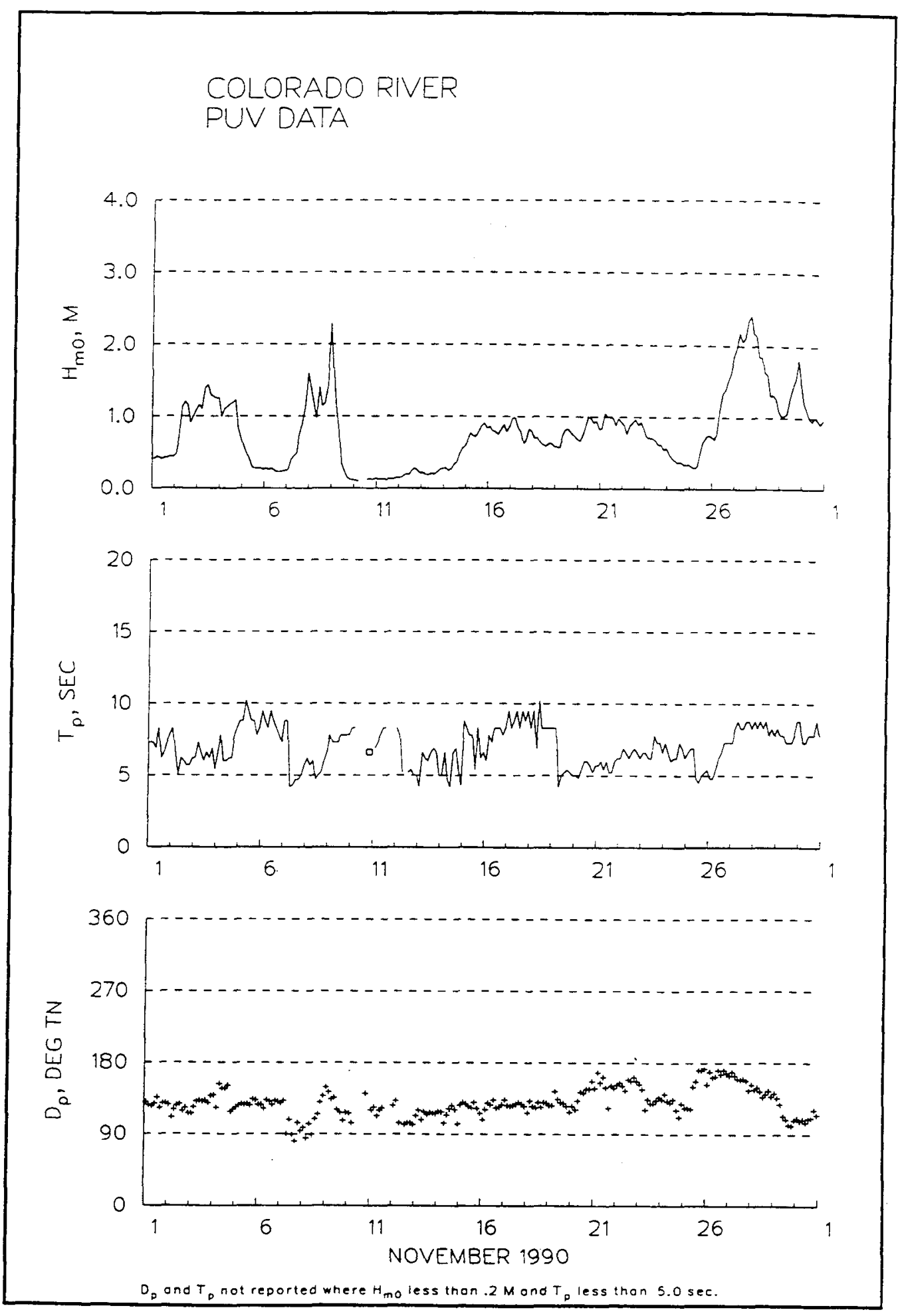




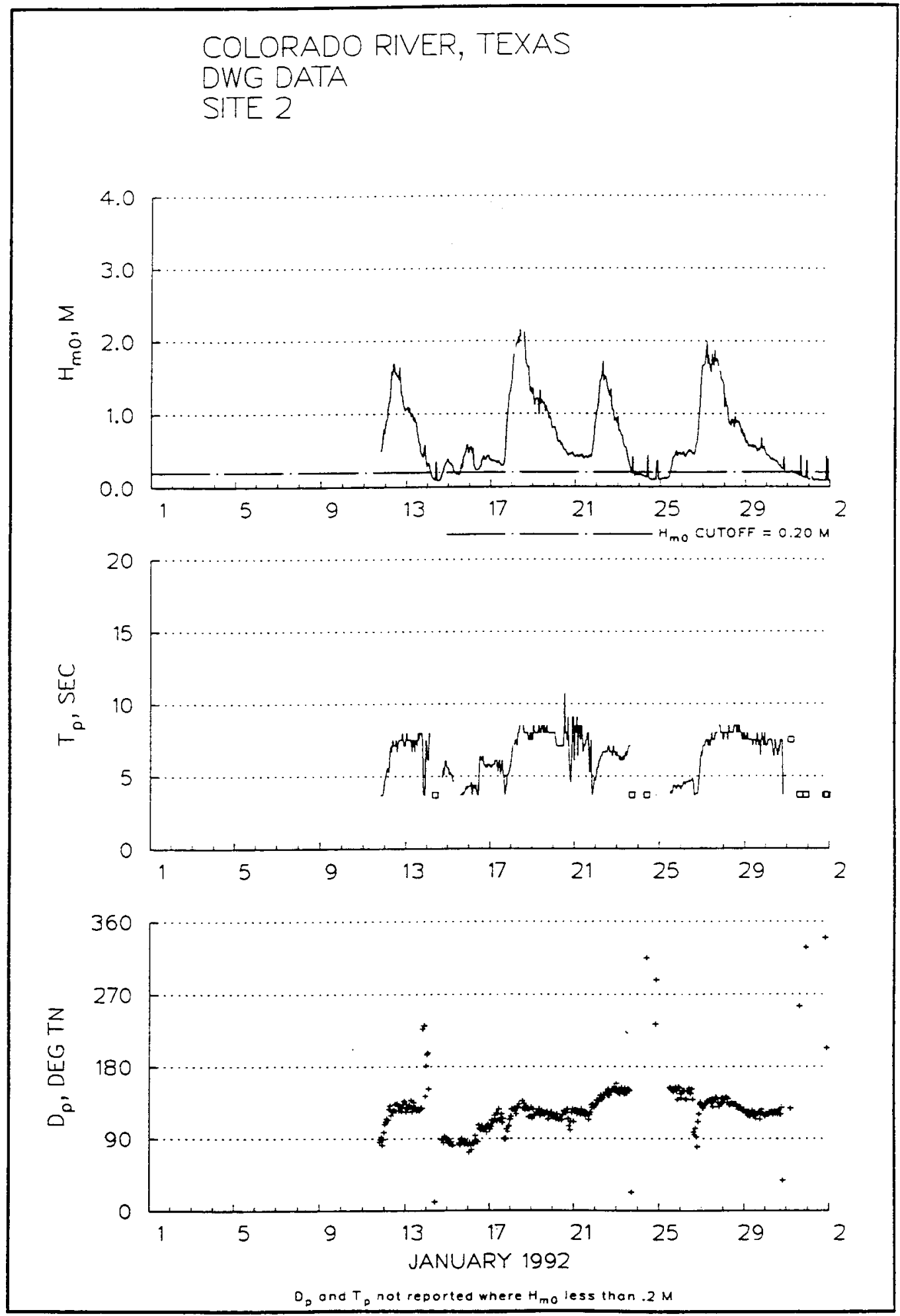




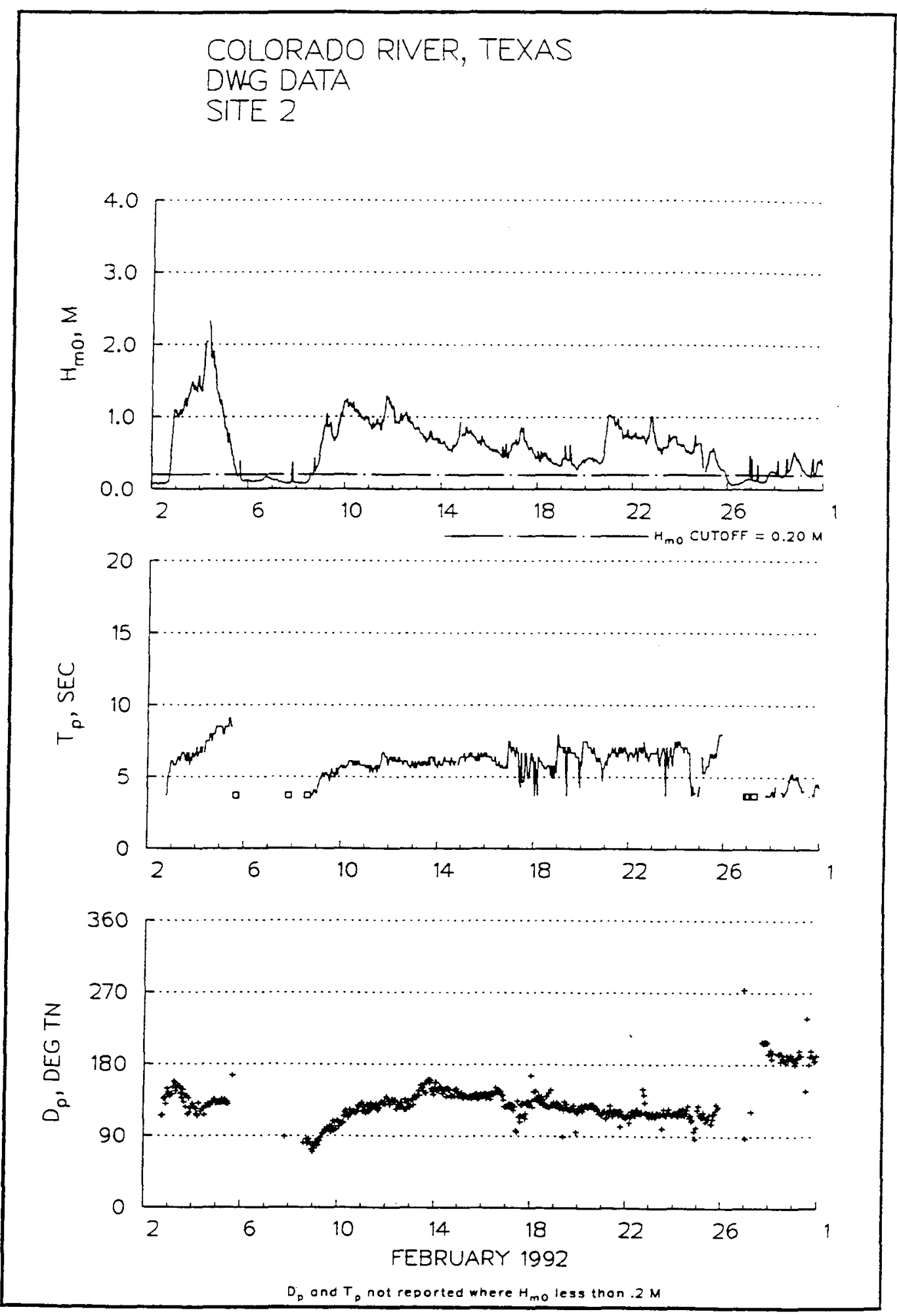




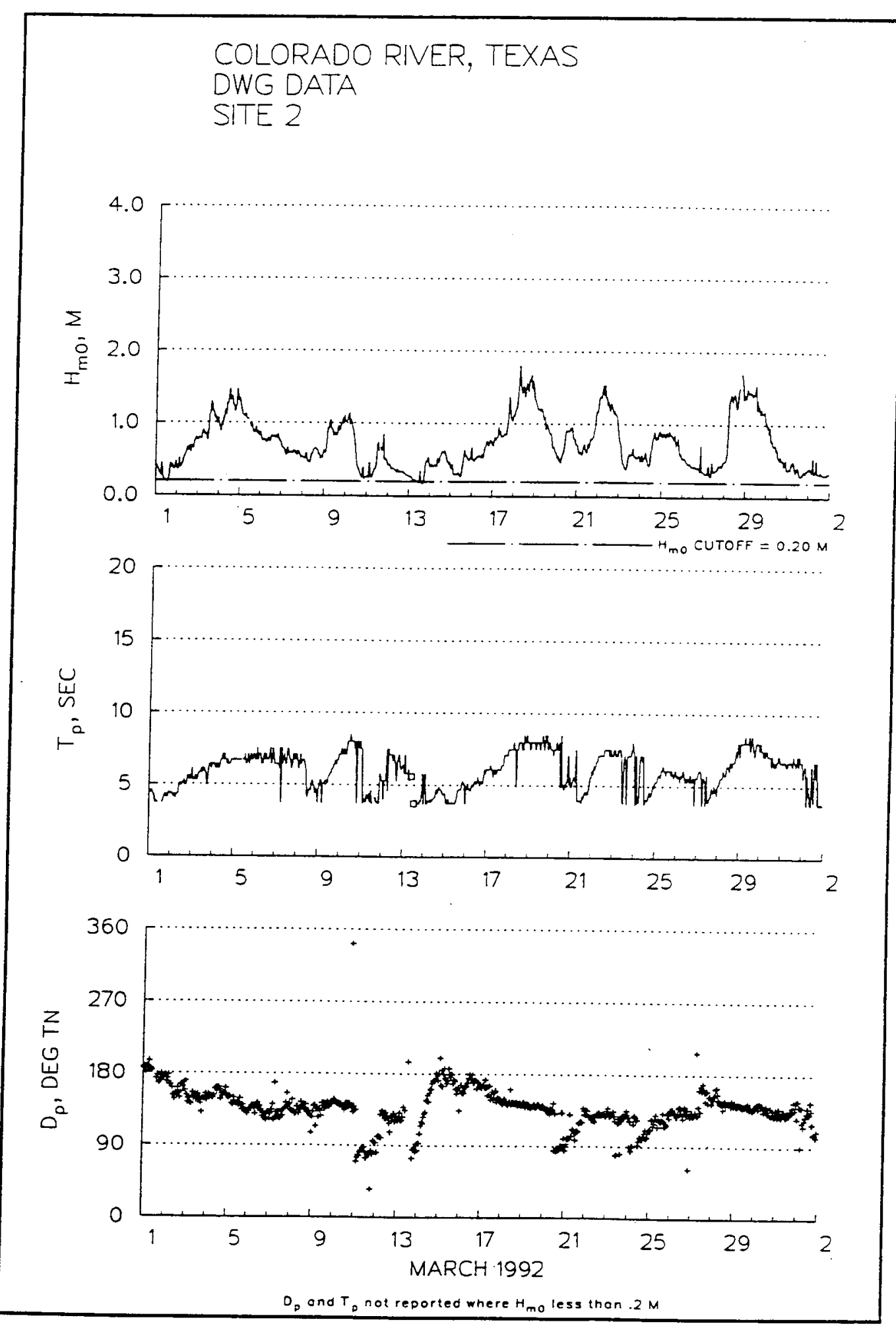




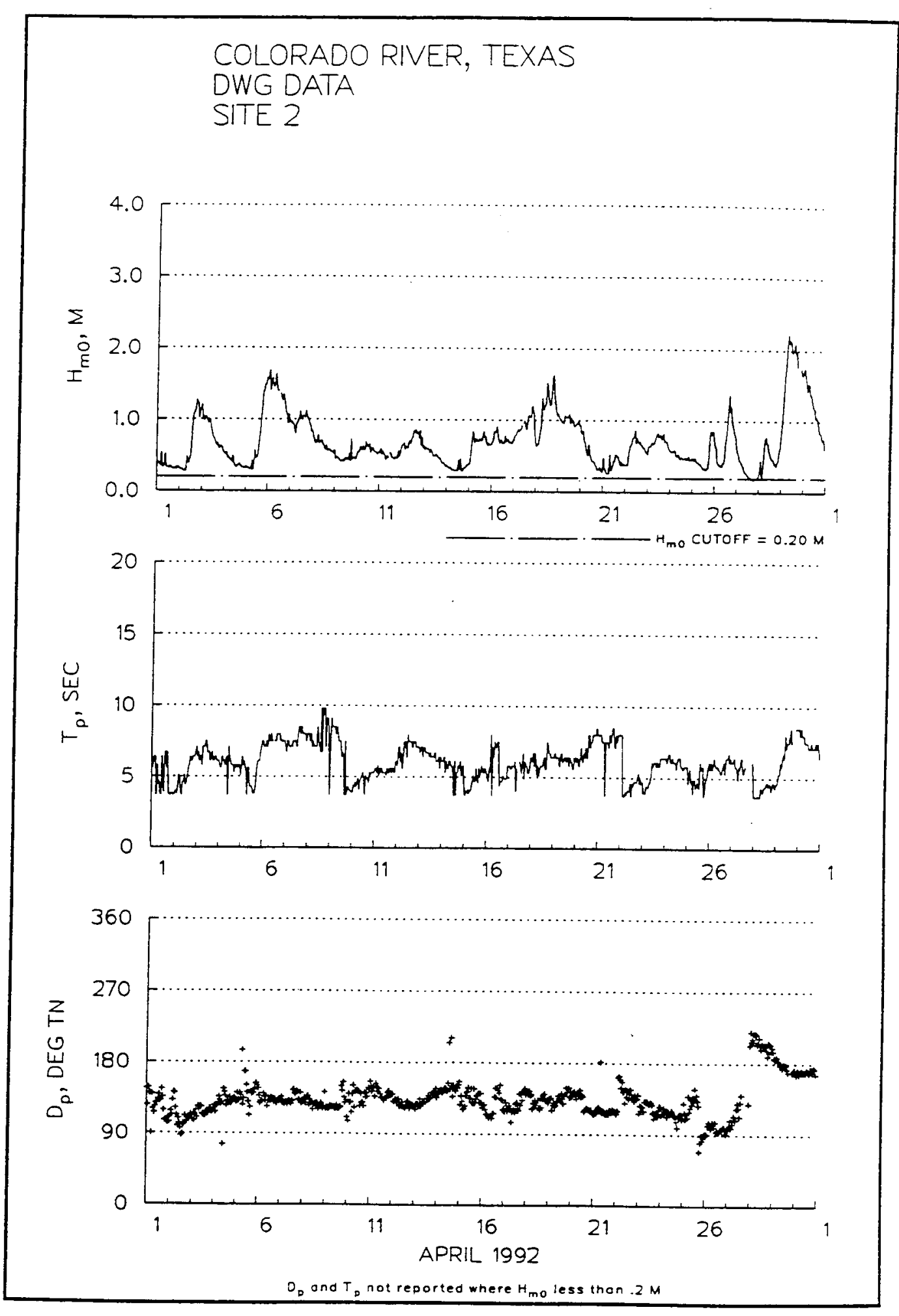




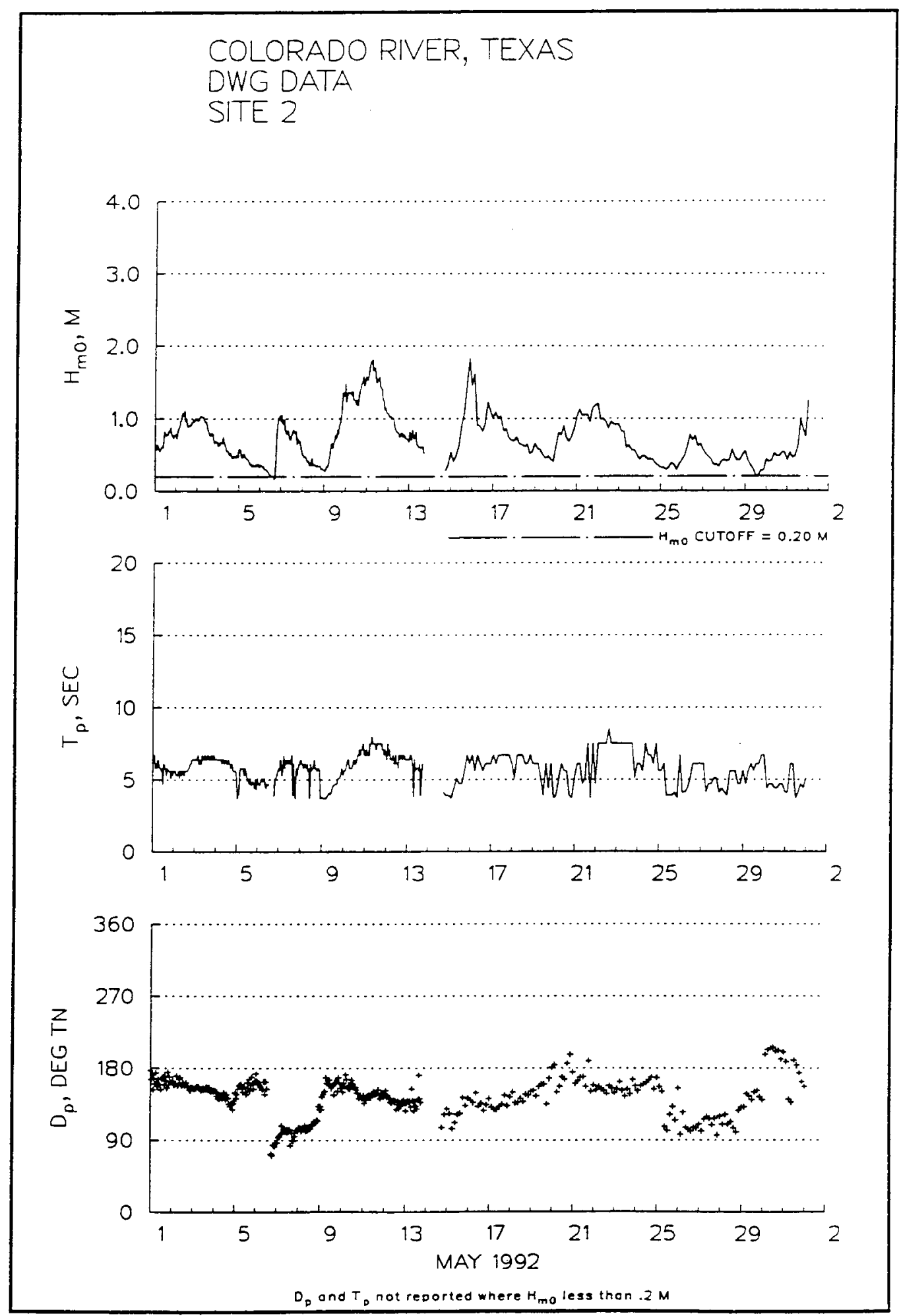




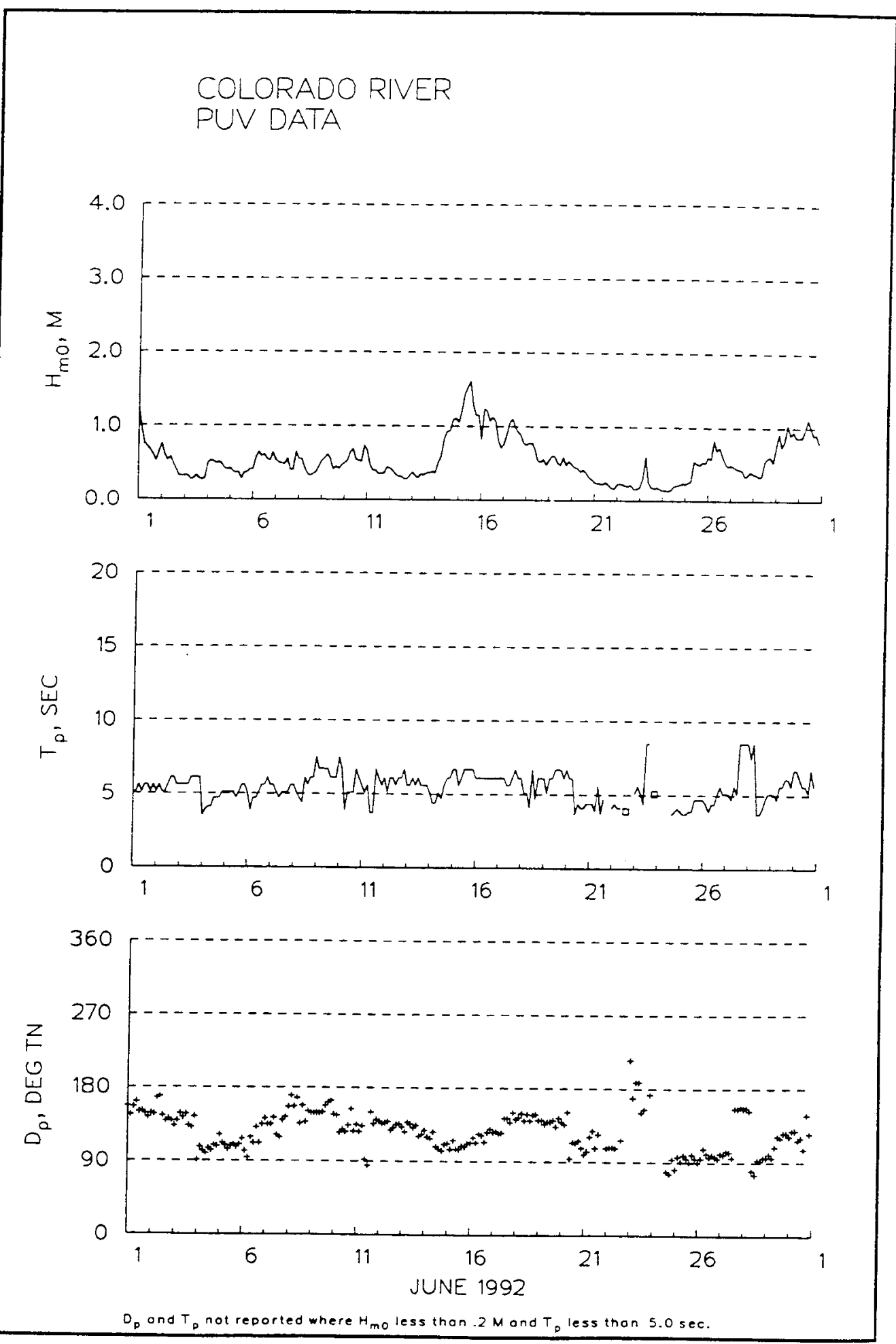




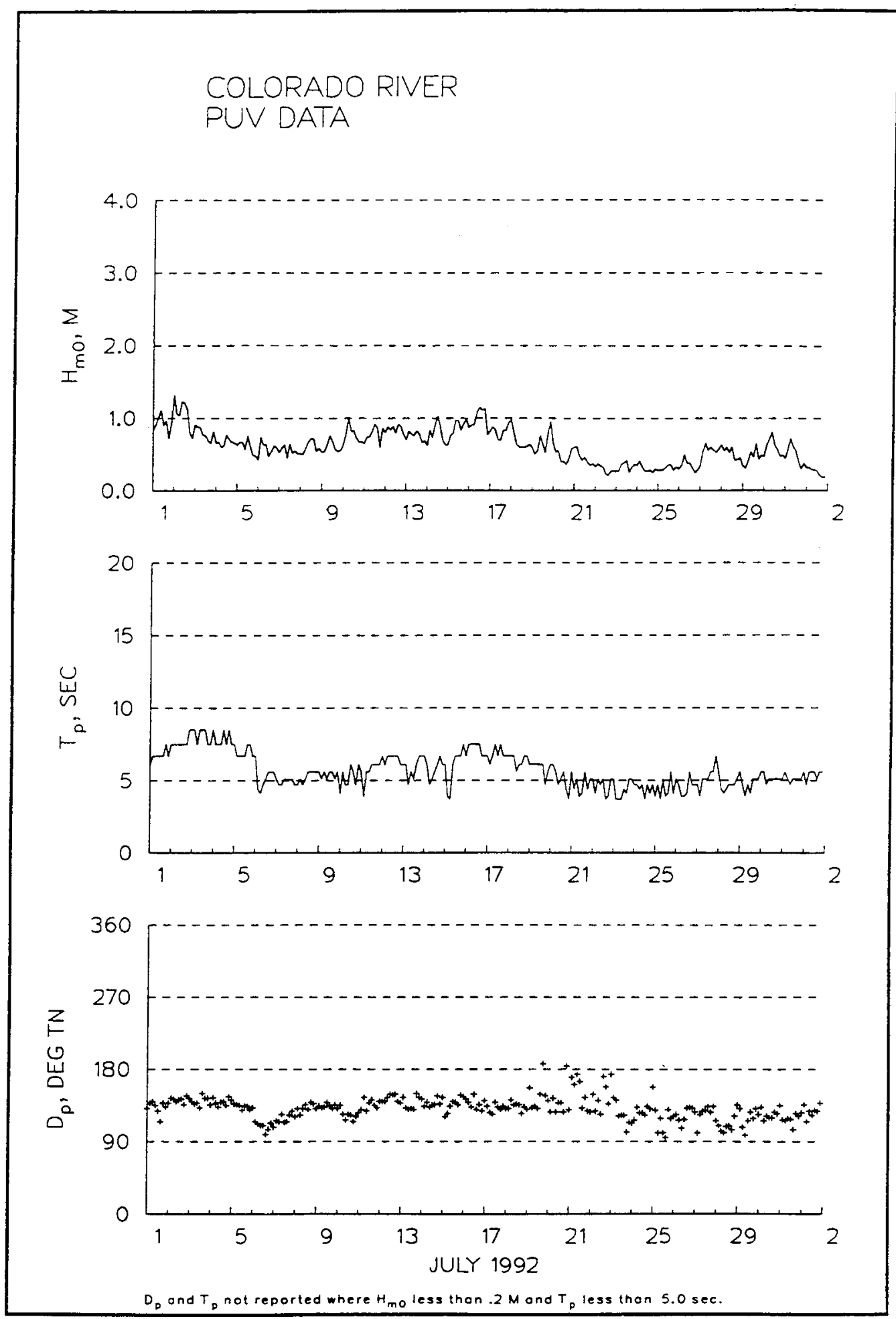




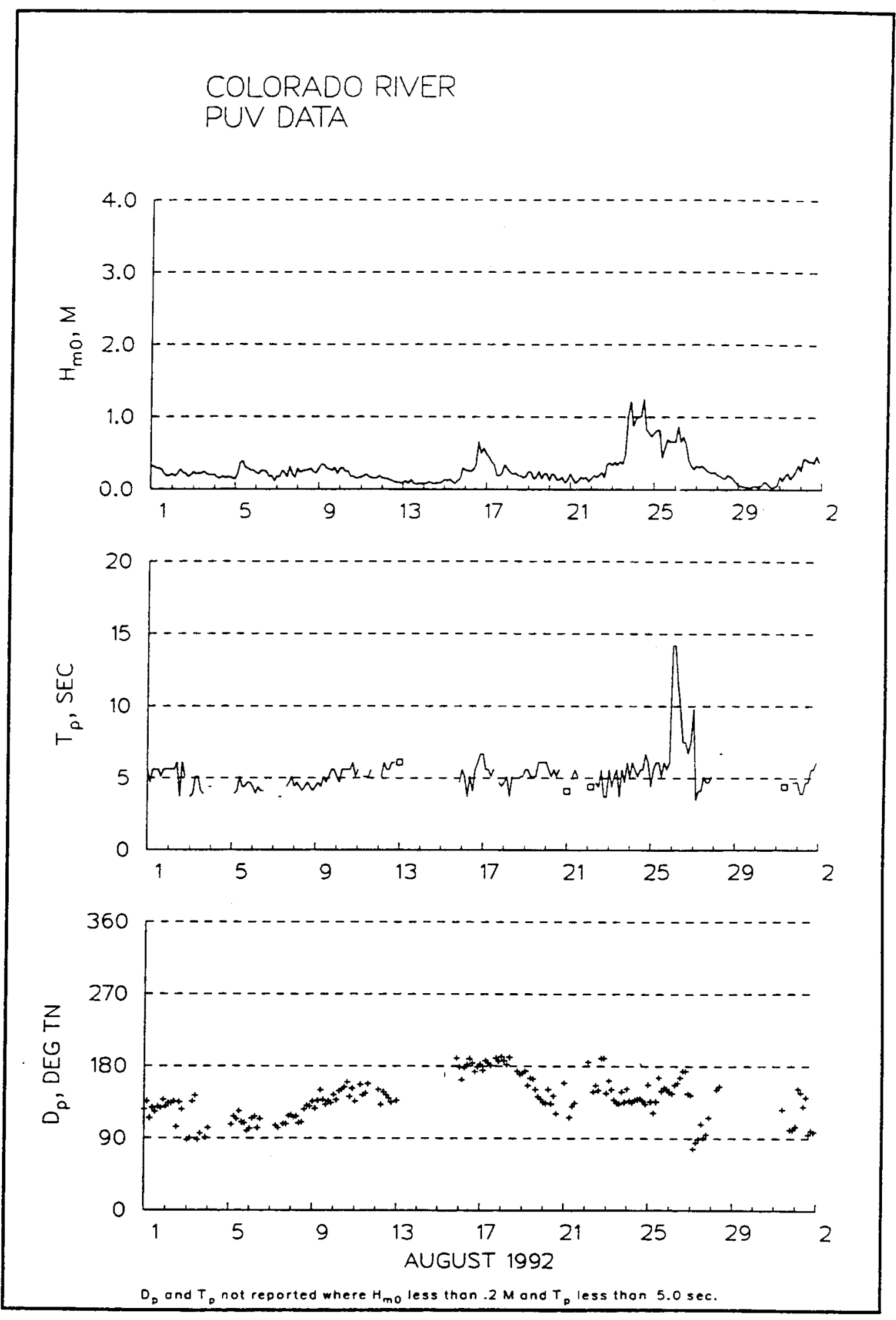




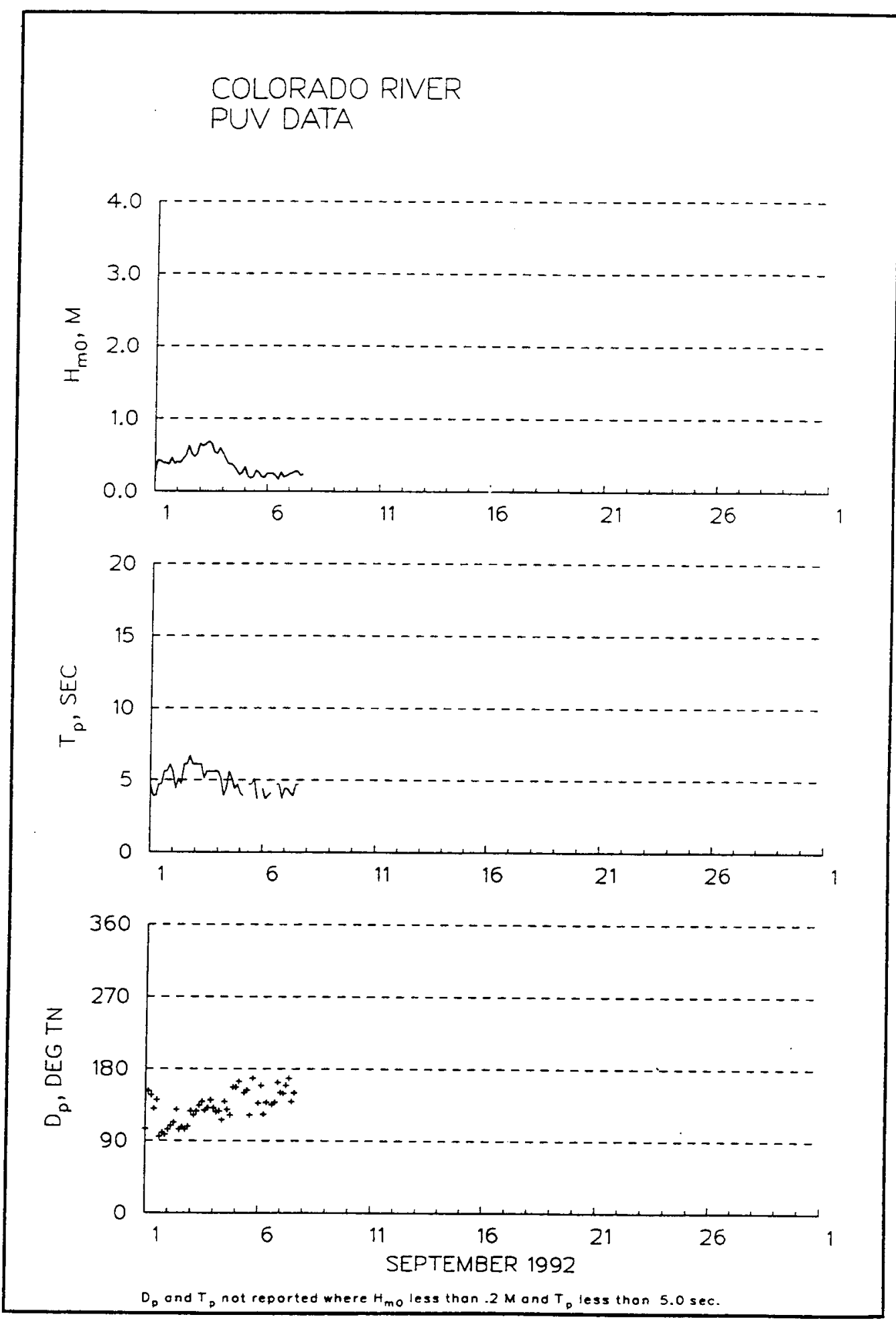

Appendix B Summary of All Wave Heights, Periods, and Directions 


\section{Appendix C Surf Zone Sediment Transport Rates}




\begin{tabular}{|c|c|c|c|}
\hline \multicolumn{4}{|c|}{$\begin{array}{l}\text { Table C1 } \\
\text { Surf Zone Sediment Transport Measurements From } \\
\text { Platform and Sled (from White 1992) }\end{array}$} \\
\hline Date & $\begin{array}{c}\text { Time }^{1} \\
\text { EST }\end{array}$ & Sled No. ${ }^{2}$ & $\begin{array}{c}\mathrm{Q}^{3} \\
\text { cubic meters }\end{array}$ \\
\hline 910716 & 1313 & & -1.17 \\
\hline 910716 & 1426 & & -0.22 \\
\hline 910716 & 1511 & & 0.32 \\
\hline 910717 & 1056 & & 0.14 \\
\hline 910717 & 1213 & & 0.13 \\
\hline 910717 & 1414 & & 0.09 \\
\hline 910718 & 0905 & & -0.69 \\
\hline 910718 & 1038 & & -0.81 \\
\hline 910718 & 1354 & & -0.13 \\
\hline 910718 & 1619 & & -0.17 \\
\hline 910718 & 1737 & & -0.15 \\
\hline 910719 & 0956 & & -1.86 \\
\hline 910719 & 1227 & & -1.77 \\
\hline 910719 & 1459 & & -1.25 \\
\hline 910720 & 0843 & & -0.04 \\
\hline 910720 & 1122 & & -0.17 \\
\hline 910720 & 1350 & & 0.07 \\
\hline 910720 & 1620 & & -1.94 \\
\hline 910721 & 0936 & & 0.93 \\
\hline 910721 & 0936 & 1 & 0.44 \\
\hline 910721 & 1216 & & -0.06 \\
\hline 910721 & 1216 & 1 & 0.48 \\
\hline 910721 & 1304 & & 0.85 \\
\hline \multicolumn{4}{|c|}{ (Continued) } \\
\hline \multicolumn{4}{|c|}{$\begin{array}{l}1 \text { Start time of the data run } \\
2 \text { Measurements are from the shallow-water platform } \\
\text { unless otherwise indicated. } \\
{ }^{3} Q \text { is the vertically integrated average sediment } \\
\text { transport rate during the data run in cubic meters per } 1-m \\
\text { width of the surf zone per hour. Positive transport } \\
\text { direction is to the southwest (toward Mexico). }\end{array}$} \\
\hline
\end{tabular}




\begin{tabular}{|c|c|c|c|}
\hline Date & $\begin{array}{l}\text { Time } \\
\text { EST }\end{array}$ & Sled No. & $\begin{array}{c}\mathrm{Q} \\
\text { cubic meters }\end{array}$ \\
\hline 910721 & 1422 & 1 & 0.24 \\
\hline 910721 & 1537 & 1 & 0.18 \\
\hline 910722 & 0848 & & 1.72 \\
\hline 920110 & 1716 & & 5.57 \\
\hline 920110 & 1758 & & 6.05 \\
\hline 920111 & 1244 & & 2.45 \\
\hline 920111 & 1446 & & 1.56 \\
\hline 920111 & 1621 & & 3.60 \\
\hline 920111 & 1722 & & 3.49 \\
\hline 920112 & 1134 & & 3.41 \\
\hline 920113 & 1351 & & -1.67 \\
\hline 920113 & 1531 & 1 & -1.89 \\
\hline 920114 & 1000 & 1 & 0.00 \\
\hline 920114 & 1825 & 1 & 0.00 \\
\hline 920114 & 1825 & 1 & 0.00 \\
\hline 920114 & 1825 & 1 & 0.00 \\
\hline 920115 & 1405 & 1 & 0.00 \\
\hline 920116 & 1504 & & -0.33 \\
\hline 920116 & 1743 & 1 & -1.22 \\
\hline 920117 & 1206 & & 3.65 \\
\hline 920117 & 1229 & & 2.56 \\
\hline 920117 & 1256 & & 6.24 \\
\hline 920117 & 1322 & & -8.14 \\
\hline 920117 & 1545 & & 4.90 \\
\hline 920117 & 1625 & & 5.15 \\
\hline 920118 & 0955 & & 10.76 \\
\hline 920118 & 1037 & & 10.19 \\
\hline
\end{tabular}




\begin{tabular}{|c|c|c|c|}
\hline \multicolumn{4}{|c|}{$\begin{array}{l}\text { Table C2 } \\
\text { Surf zone Sediment Transport Measurements From FOBS } \\
\text { Tripods (from Beach 1995). }\end{array}$} \\
\hline Date & $\begin{array}{l}\text { Time }^{1} \\
\text { EST } \\
\end{array}$ & Tripod & $\begin{array}{c}\mathrm{Q}^{2} \\
\text { cubic meters } \\
\end{array}$ \\
\hline 910721 & 0955 & A & -0.0523 \\
\hline 910721 & 1330 & A & -0.1143 \\
\hline 910721 & 1555 & A & -0.3464 \\
\hline 910723 & 1100 & $\mathrm{~A}$ & 0.0026 \\
\hline 910723 & 1340 & A & -0.0799 \\
\hline 910723 & 1340 & $B$ & 0.5689 \\
\hline 910724 & 1025 & A & 0.0016 \\
\hline 910724 & 1025 & B & 0.0095 \\
\hline 910724 & 1130 & A & 0.0012 \\
\hline 910724 & 1130 & B & 0.0094 \\
\hline 910724 & 1347 & $\mathrm{~A}$ & 0.0008 \\
\hline 910724 & 1347 & B & 0.0313 \\
\hline 910724 & 0850 & $\mathrm{~A}$ & 0.0052 \\
\hline 910725 & 0850 & B & 0.0289 \\
\hline 910725 & 1058 & B & 0.0272 \\
\hline 920112 & 1611 & A & 0.0068 \\
\hline 920113 & 1351 & $B$ & 0.0156 \\
\hline 920113 & 1556 & B & -0.0007 \\
\hline 920116 & 1255 & B & -0.0070 \\
\hline \multicolumn{4}{|c|}{$\begin{array}{l}\text { Start time of the data run. } \\
{ }^{2} Q \text { is the vertically integrated average sediment } \\
\text { transport rate during the data run in cubic meters per } 1-m \\
\text { width of the surf zone per hour. Positive transport } \\
\text { direction is to the southwest (toward Mexico). }\end{array}$} \\
\hline
\end{tabular}


Public reporting burden for this collection of information is estimated to average 1 hour per response, including the time for reviewing instructions, searching existing data sources, gathering and maintaining the data needed. and completing and reviewing the collection of information. Send comments regarding this burcten estimate or any other aspect of this coltection of information, inctuding suggestions for reducing this burden, to Wastington Headquarters Services, Directorate for Information Operations and Reports, 1215 Jefferson Davis Highway, Suite 1204, Artington, VA 22202-4302, and to the Office of Management and Budget, Paperwork Reduction Project (0704-0188), Wastington, DC 20503.

\begin{tabular}{|l|l|l|l}
\hline 1. AGENCY USE ONLY (Leave blank) & $\begin{array}{l}2 \text { REPORT DATE } \\
\text { January } 1998\end{array}$ & $\begin{array}{l}\text { 3. REPORT TYPE AND DATES COVERED } \\
\text { Final report }\end{array}$ \\
\hline
\end{tabular}

4. TITLE AND SUBTITLE

Mouth of the Colorado River, Texas Monitoring Program

5. FUNDHNG NUMBERS

MCNP Work Unit 22113

6. AUTHOR(S)

David B. King, Terri L. Prickett

7. PERFORMING ORGANIZATION NAME(S) AND ADDRESS(ES)

U.S. Army Engineer Waterways Experiment Station

3909 Halls Ferry Road, Vicksburg, MS 39180-6199

8. PERFORMING ORGANIZATION REPORT NUMBER

Technical Report CHL-98-2

9. SPONSORINGMONITORING AGENCY NAME(S) AND ADDRESS(ES)

U.S. Army Corps of Engineers

10. SPONSORINGMONTORING

Washington, DC 20314-1000

AGENCY REPORT NUMBER

\section{SUPPLEMENTARY NOTES}

Available from National Technical Information Service, 5285 Port Royal Road, Springfield, VA 22161.

\section{2a. DISTRIBUTIONAVAILABILTY STATEMENT}

12b. DISTRIBUTION CODE

Approved for public release; distribution is unlimited.

\section{ABSTRACT (Maximum 200 mords)}

This report provides an overview of the monitoring effort of the U.S. Army Corps of Engineers at the mouth of the Colorado River, Texas. The report includes background information and objectives of the study, which were as follows:

a. Evaluate the design and efficiency of the weir jetty and adjacent impoundment basin so that project maintenance requirements and costs can be more accurately established.

b. Develop and improve equations for computing longshore sediment transport in the vicinity of the Colorado River, Texas.

c. Determine which sediment transport equations work best in the surf zone.

d. Collect data to aid in efforts to improve future designs of similar Corps projects.

The report also includes data collection plans and procedures, data analysis, an evaluation of the project, and conclusions and recommendations. The data collection effort was divided into three main components: deployment of offshore directional wave sensors to obtain long-term, continuous wave, current, and water level information; intense, short-term field experiments that principally collected sediment transport data in the surg zone; and bathymetry surveys of the adjacent shorelines.

\begin{tabular}{|c|c|c|c|}
\hline & $\begin{array}{l}\text { SUBJECT TERMS } \\
\text { Colorado River, Texas } \\
\text { Longshort sediment transport } \\
\text { MCNP Program }\end{array}$ & & $\begin{array}{l}\text { Surf zone } \\
\text { Wave sensors }\end{array}$ \\
\hline 17. & $\begin{array}{l}\text { SECURTY CLASSIFICATION } \\
\text { OF REPORT } \\
\text { UNCLASSIFIED }\end{array}$ & 18. & $\begin{array}{l}\text { SECURTY CLASSIFICATION } \\
\text { OF THIS PAGE } \\
\text { UNCLASSIFIED }\end{array}$ \\
\hline
\end{tabular}

NSN 7540-01-280-5500
15. NUMBER OF PAGES 98

16. PRICE CODE
19. SECURITY CLASSIFICATION OF ABSTRACT

20. UMTTATION OF ABSTRACT 
Destroy this report when no longer needed. Do not return it to the originator. 